\title{
Autoimmunity and effect of ageing
}

Citation for published version (APA):

Crisi, G. M. (1999). Autoimmunity and effect of ageing. [Doctoral Thesis, Maastricht University]. Universiteit Maastricht. https://doi.org/10.26481/dis.19990129gc

Document status and date:

Published: 01/01/1999

DOI:

10.26481/dis.19990129gc

Document Version:

Publisher's PDF, also known as Version of record

\section{Please check the document version of this publication:}

- A submitted manuscript is the version of the article upon submission and before peer-review. There can be important differences between the submitted version and the official published version of record.

People interested in the research are advised to contact the author for the final version of the publication, or visit the DOI to the publisher's website.

- The final author version and the galley proof are versions of the publication after peer review.

- The final published version features the final layout of the paper including the volume, issue and page numbers.

Link to publication

\footnotetext{
General rights rights.

- You may freely distribute the URL identifying the publication in the public portal. please follow below link for the End User Agreement:

www.umlib.nl/taverne-license

Take down policy

If you believe that this document breaches copyright please contact us at:

repository@maastrichtuniversity.nl

providing details and we will investigate your claim.
}

Copyright and moral rights for the publications made accessible in the public portal are retained by the authors and/or other copyright owners and it is a condition of accessing publications that users recognise and abide by the legal requirements associated with these

- Users may download and print one copy of any publication from the public portal for the purpose of private study or research.

- You may not further distribute the material or use it for any profit-making activity or commercial gain

If the publication is distributed under the terms of Article $25 \mathrm{fa}$ of the Dutch Copyright Act, indicated by the "Taverne" license above, 
Autoimmunity and effect of ageing 
Giowama C. Crist, Maastricht 1999, the Netherlands ISBN $90-5681-053-7$

\section{Lay-out}

Anita Meijers-Blommers

\section{Printed by}

Unigraphic, Maastrictht the Netherlends

\section{Coner illustration}

Micrograph of neonatal thymus 


\title{
Autoimmunity and effect of ageing
}

\author{
PROEFSCHRIFT
}

ter verkrijging van de graad van doctor

aan de Universiteit Maastricht,

op gezag van de Rector Magnificus,

Prof.dr. A.C. Nieuwenhuijzen Kruseman

volgens het besluit van het College van Decanen

in het openbaar te verdedigen

op vrijdag 29 januari 1999 om 12.00 uur

door

Giovanna M. Crisi 


\section{Promotor}

Prof.dr. P.I.C. van Breda Vriesman

\section{Compromotor}

Prof.dr. G.J. Thorbecke (New York University School of Medicine)

\section{Beoordelingsicommissie}

Prof.dr. J.W. Arends, voorzitter

Prof.dr. H.F. Hillen

Prof.dr. P. Nieuwenhuis (Rijksuniversiteit Groningen)

Prof.dr. F.C.S. Ramaekers 


\section{Table of Contents}

List of abbreviations

Introduction 7

CHAPTER 1

Tolerance to self and immunoregulation: A Literature review

CHAPTER 2

Age-related loss of immunoregulatory function in peripheral blood CD8 T cells

CHAPTER 3

Evaluation of presence and functional activity of potentially self-reactive $T$ cells in aged mice

CHAPTER 4

Tolerogenic forms of auto-antigens and cytokines in the induction of resis-tance to experimental allergic encephalomyelitis

\section{CHAPTER 5}

Staphylococcal enterotoxin B and tumor necrosis factor- $\alpha$-induced relapses of experimental allergic encephalomyelitis: protection by transforming growth factor- $\beta$ and interleukin-10

Thesis summary

Samenvatting

Acknowledgments

Publications

Curriculum vitae 


\section{LIST OF ABBREVIATIONS}

$\begin{array}{ll}\text { AET } & \text { 2-Aminoethylisothiouronium bromide } \\ \text { APC } & \text { Antigen Presenting Cell } \\ \text { ATCC } & \text { American Tissue Culture Cooperation } \\ \text { CM } & \text { Culture medium } \\ \text { CSA } & \text { Cyclosporin A } \\ \text { DP } & \text { Double positive } \\ \text { DTH } & \text { Delayed type hypersensitivity } \\ \text { EAE } & \text { Experimental allergic encephalomyelitis } \\ \text { ECDI } & \text { 1-ethyl-3-(3-dimethyl-aminopropyl)-carbodimide.HCl } \\ \text { IEL } & \text { Intestinal epithelial lymphocytes } \\ \text { IFN- } \gamma & \text { Interferon-gamma } \\ \text { ISC } & \text { Immunoglobulin secreting cells } \\ \text { LN } & \text { Lymph node(s) } \\ \text { MSCH } & \text { Mouse spinal cord homogenate } \\ \text { PBL } & \text { Peripheral blood lymphocytes } \\ \text { PBMC } & \text { Peripheral blood mononuclear cell(s) } \\ \text { PE } & \text { Phycoerythrin } \\ \text { PLP } & \text { Proteolipid protein } \\ \text { PWM } & \text { Pokeweed mitogen } \\ \text { (SxB)F1 } & \text { (SJL/I } x \text { BALB/c)Fl } \\ \text { SAC } & \text { Staphylococcus aureus Cowan I strain } \\ \text { SEB } & \text { Staphylococcal enterotoxin B } \\ \text { SRBC } & \text { Sheep red blood cells } \\ \text { TCR } & \text { T cell receptor } \\ \text { TGF } & \text { Transforming growth factor } \\ \text { Th } & \text { T helper cell(s) } \\ \text { TNF } & \text { Tumor necrosis factor } \\ \text { TX } & \text { Thymectomized } \\ & \\ \text { PW } & \end{array}$




\section{Introduction}

The education of the immune system depends on a complex interaction between cells within the physiologic microenvironment of the lymphoid organs, and progresses along very specific pathways. At any point during the development of immunocompetent cells, whether due to a pathological dysfunction or physiological disequilibrium, alterations can occur, leading to a potential imbalance between protective and disruptive factors. When we talk about autoimmunity, we immediately think about a pathological state in which there is loss of self-tolerance associated with an immune reaction against self-tissue. This does not necessarily cause disease because many individuals harbor autoantibodies and self-reactive $T$ cells but are "healthy" nevertheless. Thus the presence of autoreactive components could imply some kind of immune regulation to maintain a state of tolerance. Nonetheless, autoimmune disorders do arise when mechanisms to maintain self-tolerance become deficient.

In the work presented, we focus on two examples in which the immune system can cause autoimmune phenomena: Ageing, a physiologic alteration of the immune system, and EAE, a pathological organ-specific autoimmune reaction.

Chapter 1 consists of a literature review which deals with tolerance to self and immune regulation and some aspects of the effect of aging on the immune system.

In Chapter 2, we have described in vitro studies with human lymphocytes from young and aged individuals. Here we compare different age groups with respect to the functional effects of $T$ cells on $\mathrm{T}$-independently activated $\mathrm{B}$ cells. The T-B cell interaction in the system used shows that $\mathrm{CD} 8^{+} \mathrm{T}$ cells from young individuals down regulate $\mathrm{Ig}$ secretion by SAC and IL-2 activated B cells, while $\mathrm{T}$ cells from aged individuals do not. Whether the defect of the aged subjects $\mathrm{CD} 8^{+} \mathrm{T}$ cells is secondary to a deficient intracellular signal transduction, or a deficient production of immunoregulatory cytokines, such as TGF- $\beta$, is discussed. Defective regulation of autoreactive antibody producing $B$ cells could be the result of this $C D 8^{+} \mathrm{T}$ cell defect.

The idea that autoreactive $T$ cells might escape to the periphery from the involuted thymus of aged mice, as opposed to the normal thymus of young mice, is addressed in Chapter 3 by in vivo studies in mice. We looked for the presence and functional activity of $\mathrm{T}$ cells bearing self-reactive TCR-V $\beta$ chains in the peripheral tissue of aged animals. Results are presented concerning young, aged and aged thymectomized mice of different strains. The study on mice thymectomized at $4-6$ month of age provides some insight into the recent thymic or extrathymic origin of potentially self-reactive T cells.

Possible methods of preventing autoimmune diseases in animals are immune deviation, immune suppression and anergy. These are the subjects of the remaining chapters. In Chapter 4 , we 
reinvestigate the mechanisms of tolerance to intravenously injected encephalitogenic peptide PLP 139-151, and analyze the immunoregulatory effect of different cytokines in this model. The administration of $\mathbb{L}-2$ at a specific time after the induction of tolerance abrogates this form of tolerance, suggesting a role for the induction of anergy by i.v. administered PLP.

In addition, we show the capacity of $T$ cells from these mice to transfer this resistance to EAE induction to naive recipients, indicating a component of immunoregulatory $T$ cells. In the same chapter, we also present data on the immunomodulation of EAE devellopment by cytokines. Downregulating effects of TGF- $\beta$ and $\mathrm{IL}-4$ on EAE are shown to require different temporal relationships between cytokine administration and EAE induction.

Certain forms of EAE and multiple sclerosis are both subject to spontaneous remissions and relapses. In Chapter 5, we examine the ability of the superantigen, Staphylococcal Enterotoxin B (SEB), and of the pro-inflammatory cytokine TNF- $\alpha$ to induce relapses in mice after recovery from acute EAE. We also show the immunoregulatory effect of different cytokines on such relapses. 
Chapter

1

Tolerance to self and immunoregulation: A literature review 
The functional diversity of the immune system is generated during embryonic life by differentiation of cell populations with defined functions. $T$ and $B$ lymphocytes are the predominant immune cells and develop from a common stem cell. The primary lymphoid organs are the bone marrow and thymus where $\mathrm{B}$ and $\mathrm{T}$ cells, respectiwely, develop into immunocompetent cells. The secondary lymphoid organs allow for interaction and expansion of these immunocompetent cells, for presentation of foreign antigen and are the sites where immune responses are generated. These are specific protective responses and are usually directed against foreign antigens. However certain circumstances arise in which selfdiscrimination fails and the system reacts against self antigens, resulting in autoimmune processes.

To understand the mechanism of autoimmunity it is necessary to comprehend how the immune system protects the body from "self-destruction", and hence how the body becomes tolerant to self-tissue. Historically the concept of "tolerance' was first described by Paul. Ehrlich at the turn of the century ${ }^{\prime}$, but only much later the actual understanding of the mechanism of tolerance started to be appreciated. The clonal selection theory introduced by Bumet stated that self-tolerance is achieved by the elimination of autoreactive clones during the differentiation of the immune system ${ }^{2}$. At present three mechanisms have been proposed to explain the state of tolerance to self: clonal deletion in the thymus, peripheral clonal anergy and/or deletion and peripheral suppression. These mechanisms are briefly described in the following paragraphs.

\section{Central mechanisms}

Clonal selection is the earliest mechanism of immune cell education towards tolerance and is subdivided in positive and negative selection ${ }^{3,4}$. It is within the thymus that immature $T$ lymphocytes are educated to become competent immune cells. The thymic microenviromment plays an essential role in this process 5 . The thymic non-lymphoid cells are bonemarrow derived dendritic cells, macrophages and thymic epithelial cells. These cells function as antigen presenting cells (APC"s), antigen being presented in the context of self-MHC, and play specific roles during the developmental steps of the differentiating $T$ cells.

The earliest step in the maturation of the T cells includes rearrangement of the genomic DNA resulting in genes that encode the $\alpha$ and $\beta$ TCR chains on T cells ${ }^{6}$. First the TCR $\beta$ gene is rearranged and expressed, allowing for expression of the pre-T cell receptor (TCR) consisting of the pre $\alpha$ and $\beta$ chains on $\mathrm{CD}^{\circ} \mathrm{CD}^{-}$(double negatiwe) thymocytes. The expression of the pre-TCR is required for progtession from the $\mathrm{CD} 4^{-} \mathrm{CD} 8^{-}$to the $\mathrm{CD} 4^{+} \mathrm{CD} 8^{*}$ step of immature thymocytes ${ }^{78,9}$. Further $\beta$ gene rearrangement is suppressed to ensure single allele expression $^{10}$. The $\alpha$ gene is rearranged and expressed, coupled to the $\beta$ chain to form a TCR $\alpha \beta$ receptor complex. At this stage the TCR $\alpha \beta$ double positive thymocytes attain the capacity to recognize antigen peptides presented in the context of self-MHC by the thymic stromal cells.

Positive selection, mediated by the TCR $\alpha \beta$ is needed for the development from $\mathrm{CD} 4^{+} \mathrm{CD} 8^{+}$ thymocytes into single positive $\mathrm{CD}^{+}$or $\mathrm{CD}^{+} \mathrm{T}$ cells. The $\mathrm{T}$ cell / stromal cell interaction will permit further selection and maturation of competent thymocytes. Further differentiation 
occurs when MHC molecules on thymic stromal cells engage with both TCR and the appropriate coreceptor, if not the cell dies (fig. 1). Thus, positive selection involves thymocytes undergoing programmed cell death (apoptosis) after failing to make a productive TCR gene rearrangement or through failure of their TCR to interact with self-MHC + selfpeptide molecules on thymic epithelial cells ${ }^{3,11}$

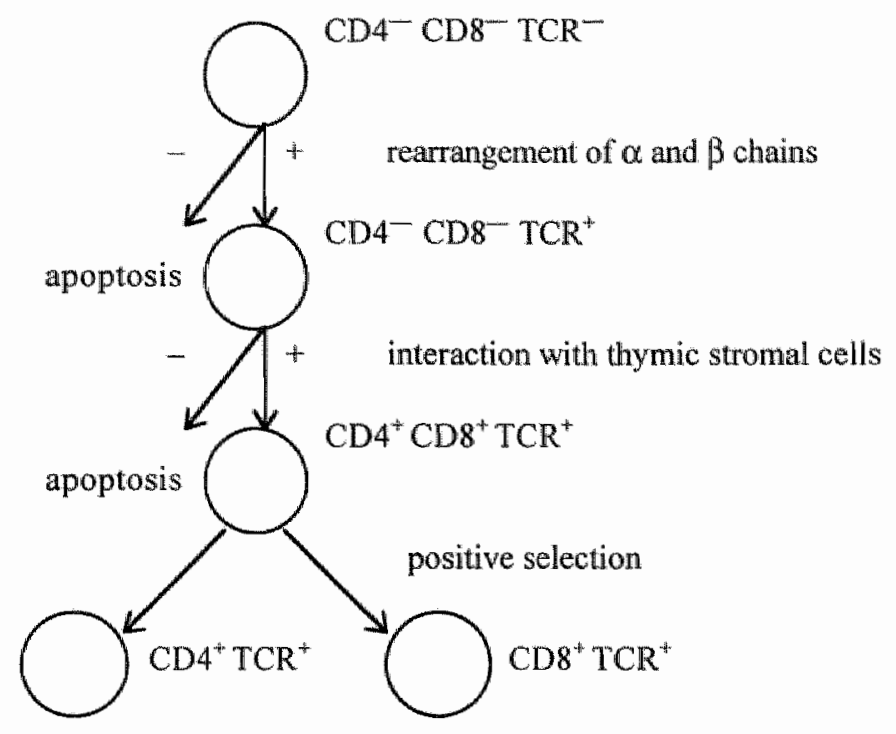

Figure 1: Steps in clonal selection. Triple negative $T$ cells undergo first rearrangement of the $T$ cell receptor $\alpha$ and $\beta$ genes, then acquire the expression of CD4 and CD8 molecules, and become triple positive. Recognition of foreign antigen in the context of self-MHC allows for positive selection and further differentiation into a single positive phenotype. Per defaull at any step of development the $T$ cell can undergo programined cell death.

Several mechanisms have been proposed to explain the developmental pathway of a doublle positive $\mathrm{T}$ cell. however it has not yet been established which model predicts CD4/CD8 lineage commitment ${ }^{12}$. These include the instructive model, in which the specificity of the TCR $\alpha \beta$ for either class I or class II MHC molecules determines whether the cells retain expression of CD8 or CD4, respectively ${ }^{13.14 .15}$; and the stochastic/selective model, which states that double positive $T$ cells randomly downregulate the expression of either CD4 or CD8, with no regard for TCR specificity ${ }^{16.17}$.

Negative selection involves apoptosis as a result of strong anti-self-reactivity against a complex of self-peptide / self-MHC. For the latter, many self-'T cell epitopes are presented by dendritic cells within the thymus and interaction with such will lead to negative selection of thymocytes bearing a TCR of sufficient affinity for this epitope. The peripheral $T$-cell pool is therefore low in self-reactive $\mathrm{T}$ cells. However, some self-antigens confined to particular tissues, e.g. brain, eye, thyroid, are not present in the thymus and thus $\mathrm{T}$ cells entering the 
periphery may still react with such self-T cell epitopes. Although positive selection precedes negative selection, these developmental steps may overlap.

\section{Peripheral mechanisms}

Clonal anergy is one of the major tolerance mechanisms for peripherally expressed tissuespecific antigens, and refers to the prolonged functional inactivation of lymphocytes. $T$ cell activation requires TCR cross-linking, CD4/CD8 interaction with MHC IV MHC I, and binding of cell adhesion molecules to their corresponding ligands ${ }^{18}$. Interaction of the activation molecules B7-1/BB1 (now designated CD80 ${ }^{19}$ ) and B7-2 ${ }^{20}$ (CD86) on antigen presenting cells with $\mathrm{CD} 28$ molecules on the $\mathrm{T}$ cell surface, is the most important molecular mechanism of costimulation for $\mathrm{T}$ cell activation ${ }^{21}$ (fig. 2). Other surface antigens, such as CD40L, on $\mathrm{T}$ cells also play an important role in costimulation ${ }^{22}$. CD40L is expressed on activated $\mathrm{T}$ cells ${ }^{23,24}$ and binds to CD 40 , a cell surface marker primarily expressed on mature B cells, follicular dendritic cells, and thymic epithelial cells ${ }^{25,26}$. Cross linking of CD40 by CD40L provides a key helper $T$ cell signal to $B$ cells $^{23,24,27,28}$. Of interest, cross-linking of CD40 induces expression of CD80 on B cells, thereby facilitating T-B cell interaction and antigen presentation by $\mathrm{B}$ cells ${ }^{29}$. CD40-CD40L interaction thus promotes the costimulation via $C D 28$. When antigen recognition occurs in the absence of a costimulatory signal, the $T$ cell may become anergic ${ }^{30}$ or $\mathrm{die}^{31}$. Anergy induced by antigen encounter in the absence of costimulatory stimuli can be reversed by exogenous IL-2 ${ }^{32,33}$. Peripheral anergy also occurs when $T$ cells are persistently stimulated with a large antigen source ${ }^{34}$, leading to deletion and exhaustion of the $T$ cell response.

With costimulation

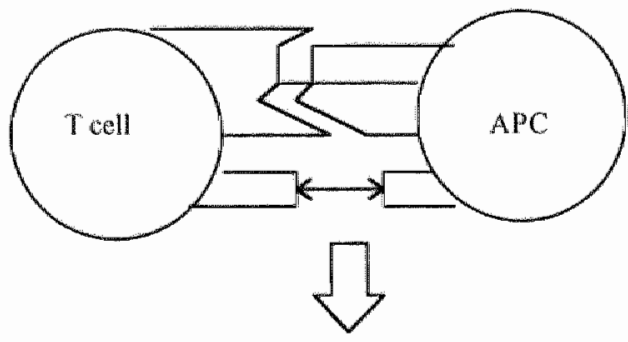

Proliferation
Without costimulation

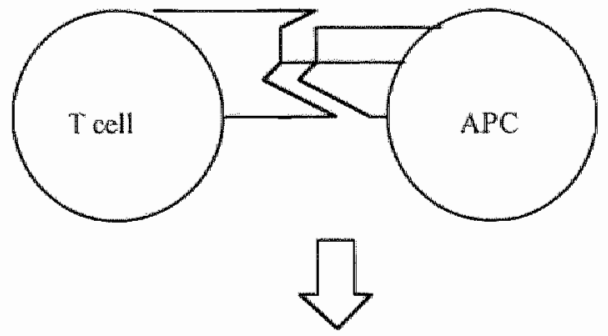

Anergy or apoplosis

Figure 2: Costimulation signals determine the outcome of the $\mathrm{T}$ cell. $\mathrm{T}$ cells recognize antigen presented in the context of MHC molecules on antigen presenting cells (APC"s). In the absence of costimulatory signals, TCR stimulation leads to induction of clonal anergy or programmed cell death. B7 on the APC reacts with $\mathrm{CD} 28$ on the $\mathrm{T}$ cell and this interaction is among the most important costimulatory signals for $\mathrm{T}$ cells. 
In addition to the affinity with which the $T$ cell recognizes antigens, the release of soluble factors by activated $T$ cells further defines the immune response. A change in the response from the formation of one set of cytokines to another is referred to as immunodeviation ${ }^{35}$.35. Two major phenotypes of T helper (Th) cells are known, Th» and Th2 cells, which reflect a differentiation phenotype of originally uncommitted $\mathrm{T}$ cells ${ }^{37.38 \%}$. Th1 cells characteristically produce $\mathbb{L}-2$, TNF and IFN- $\gamma$, play a major role in dellayed type hypersensitivity (DTH) responses, are required for protection against tumors and microorganisms, and are the promoters of cell mediated immunity. Th2 cells characteristically produce IL, $4, I L-5, \pi L-6$ and IL-10, are the primary promoters of humoral immunity and the primary suppressors of DTH responses. The differentiation of Th0 cells into Th1 or Th2 phenotype is regulated by cytokines present in the environment of the naive $T$ cell during primary stimulation ${ }^{391}$ (fig. 3 ). Naive Th cells will differentiate into Th1-like cells in the presence of $\mathrm{L}-12^{40,4}$, and into Th2. like cells in the presence of $1 \mathrm{~L}-4^{42,43}$. Aside from protection against foreign antigens, Thl and Th2 immune responses play a major role in autoimmune diseases. Th1 cells promote the development of organ specific autoimmune diseases, such as experimental allergic encephalomyelitis, rheumatoid and collagen induced arthritis, insulin dependent diabetes mellitus and acute uveoretinitis, while Th2 cells are responsible for antibody mediated diseases such as systemic lupus erythematosus, and allergic responses involving the production of $\mathrm{IgE}$. The mechanism of immunodeviation is thus important because of the potential to convert a pathologic response into a much less pathogenic or in some cases even a protective one, by altering the Th population phenotype.

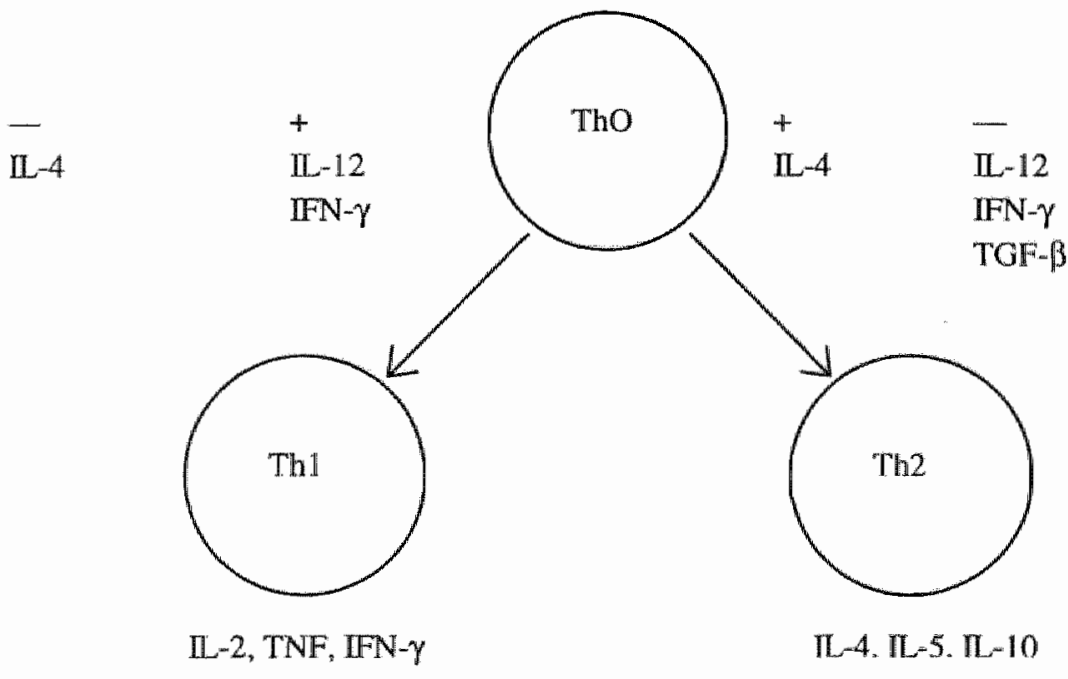

Figure 3: Differentiation pathwys of Th1 and Th2 I] cells. CD4 T cells differentiate from a naive precursor into Th1 and Th2 cells, under the influence of different cytokines. W- 12 enhances the differentiation of ThI oells and inhibits the differentiation of Th2 cells. IL-4 regulates the differentiation of "Th2 cells and inhibits the differentiation of Thl cells. Other cytokunes are also involved. 
T cell-mediated suppression, in which the auto-reactive lymphocytes are held in check by antigen-specific immunoregulatory cells, represents another mechanism by which tolerance to self can occur. The suppressor T cells can be of the CD4 or CD8 phenotype and are believed to inhibit autoreactivity by secreting cytokines such as $\mathbb{L}-10$ and/or TGF- $\beta$. IL-10 is produced by Th0 and Th2 subsets of helper T cells and by monocytes/macrophages. It suppresses both cytokine production and antigen induced proliferation of Th1 cells ${ }^{44,45,46}$. The ability of IL-10 to suppress a subset of T-cell-derived cytokines, in addition to other immunosuppresive functions ${ }^{47}$, makes it an attractive candidate for treating a variety of T-cell-mediated autoimmune diseases. TGF- $\beta$ is synthesized by a diversity of cells and essentially all cell types have a high-affinity receptor for this cytokine ${ }^{48}$. TGF- $\beta$ has many physiological effects and. can elicit diverse cellular responses, some inhibitory and some stimulatory, depending on the type of cell, its state of differentiation, and other environmental factors ${ }^{48}$. In the context of $T$ cell development, the presence of TGF- $\beta$ on thymic epithelial cells is reported as essential for the progression of developing precursor cells into DP thymocytes ${ }^{49}$. TGF- $\beta$ is a potent inhibitor of immune and inflammatory responses, as shown by the spontaneously occurring uncontrolled inflammation in TGF- $\beta 1$ knockout mice ${ }^{50.51}$. Furthermore, TGF- $\beta$ modulates $T$ cell cytokine production, inhibiting the production of IL-1, IL-4, IL-6, IFN- $\gamma$, TNF- $\alpha$, TNF- $\beta$, while $\mathbb{L L}-2$ production is not affected ${ }^{52,53,54,55,56}$. The multitude of effects of TGF- $\beta$ within the immune system play an important role in maintaining a balance between tolerance and autoimmunity. This is also evident from the immunoregulatory effect of TGF- $\beta$ in experimental autoimmune disease models.

\section{Effects of ageing on the immune system}

As for most physiologic functions, that of the immune system alters with advancing age. Thymic involution starts around puberty, and is characterized by a decrease in the lymphoid and epithelial component together with a decrease in the antigen presenting cell function of the latter. It is universally accepted that thymic output is reduced in the aged; it is not clear, however, whether positive and negative selection mechanisms continue to function normally. Conversely, extrathymically derived $\mathrm{T}$ cells are reported to increase with age $\mathrm{e}^{57.58}$.

In the periphery, $\mathrm{T}$ cells are more affected by ageing than are $\mathrm{B}$ cells, both functionally as well as in the representation of different subsets within the peripheral blood. There is a decrease in cell-mediated immunity and in the maturation of T-dependent antibody responses, in $T$ cell proliferative responses induced by antigens and mitogens, and in the synthesis of $\mathbb{L L}-2^{59}$. Some of the important changes in human $\mathrm{T}$ cell subsets reported include, a quantitative decrease in $\mathrm{CD}^{+} \mathrm{T}$ cells while the $\mathrm{CD} 4^{+} \mathrm{T}$ cells remain constant ${ }^{60}$; a relative expansion of the $\mathrm{CD} 8^{+}$ $\mathrm{CD} 28 \mathrm{cells}^{61,62}$; an increase in $\mathrm{CD}^{6} 5 \mathrm{RO}^{+}$memory $\mathrm{T}$ cells and a simultaneous decrease in $\mathrm{CD}_{5} \mathrm{RA}^{+}$virgin $\mathrm{T}$ cells $\mathrm{s}^{63,64,65}$. Aside from the decrease in $\mathrm{IL}-2$ production, IFN- $\gamma$ and $\mathbb{I L}-12$ production are also decreased, while there is a normal pattern of $\mathbb{L}-4, \mathbb{L}-5$ and $\mathrm{L}-10$ synthesis. There is a tendency to expansion of Th2-like cytokines ${ }^{66,67}$ and a decrease in Th1like cytokines, in agreement with the low $T$ cell responsiveness and normal to increased, but qualitatively inefficient, humoral immune response. In fact, an increased prevalence of serum autoantibodies and immune complexes is found in the aged population, together with an 
increase in the incidence of infectious diseases 68,69 . It should be emphasized that autoimmunity is not a characteristic of old age. Nonetheless, a large proportion of elderly people do show evidence of low grade autoimmune conditions ${ }^{70}$. Age-associated defects in B cell function are less apparent, and it is unclear whether the alterations in immune finction represent true $B$ cell changes or rather effects of a defective $T$-cell function in $T-B$ cell interactions.

One compensatory mechanism that might be active in the aged in preventing the development of autoimmunity is that $T$ cells from elderly individuals spontaneously express the Fas receptor $^{71}$. It has been suggested that the decrease in virgin $T$ cells is due to an increased susceptibility of CD45RO" $\mathrm{T}$ cells to undergo activation (PHA $+\mathbb{L}-2)$ induced apoptosis 72 These findings are important in view of recent research that has concentrated on the relation between abnormalities in apoptosis and the development of systemic autoimmunity ${ }^{73}$.

\section{Experimental Autoimmume Diseases}

Genetic and environmental factors may increase the susceptibility to develop autoimmune diseases. The understanding of organ-specific (cell-mediated) autoimmune processes has been facilitated by studies in animal models, which share some characteristics with autoimmune diseases in humans. The best characterized among these autoimmune diseases is experimental. allergic encephalomyelitis (EAE), the animal analog of the human disease multiple sclerosis. EAE is a T-cell mediated autoimmune disease induced by immunizing animals with myelin basic protein (MBP), proteolipid protein (PLP), or myelin oligodendrocyte glycoprotein $(M O G)$ in adjuvant ${ }^{74}$. After one to two weeks the animals develop encephalomyelitis characterized by perivascular inflammatory infiltrate in the white matter of the central nervous system, and demyelination. EAE is mediated by class II-restricted myelin protein specific $\mathrm{CD}^{+} \mathrm{T}$ lymphocytes. Depending on the genetic background, these $\mathrm{T}$ cells may exhibit a restricted number of $T C R \mathrm{~V} \alpha$ and $V \beta$ gene rearrangements ${ }^{75}$. The cytokines involved in disease initiation are thought to be primarily Th1-like ${ }^{75,76}$. Following the concept of immunodeviation, it would be likely that Th2 cells play a rolle in down-regulation of EAE. However, conflicting findings have recently been reported, such as 1) increased EAE in the absence of IFN $\gamma^{7}, 2$ ) transfer of EAE with Th2-like $\mathrm{CD}^{*} \mathrm{~T}$ cell clones ${ }^{7 /}$, and 3) development of EAE in $\mathrm{CD}_{4}^{-7-}$ mice ${ }^{79}$ "

\section{Summary}

Studies of self-tolerance and autoimmunity have expanded rapidly since the acceptance of the concept of clonal selection. The mechanisms that have been proposed for tolerance induction in $T$ cells are clonal deletion occuring centrally, clonal anergy and/or deletion occuring peripherally and suppression, mainly a peripheral event. The interaction of $T$ cells with the thymic and peripheral lymphoid microenvironment is essential in all these processes.

In the experimental setting there are many ways to induce autoimmune processes, such as by injection of cross reacting autoantigen. Spontaneous models of autoimmune diseases can also be used. The development of transgenic and knock-out models has clarified many points in the understanding of immune regulation and in the pathogenesis of autoimmune diseases. The 
ultimate goal is the prevention and/or amelioration of such diseases by implementing immunotherapeutic strategies.

Immunotherapy is based on the manipulation of the mechanisms involved in the physiological induction of tolerance. Antigen-based tolerance induction has been widely studied in experimental autoimmune models, and has recently also been applied to human diseases. Adoptive $\mathrm{T}$ cell therapy or $\mathrm{T}$ cell vaccination is based on priming the immune system with antigen-specific autoreactive $T$ cells / of $T$ cell receptor peptides. The exact mechanisms by which these approaches function are still unclear, but anergy and (anti-idiotypic) immunosuppression of autoreactive $T$ cells are at play. Antigen-based tolerance and $T$ cell vaccination are not preventive therapies, but rather reduce the clinical duration and degree of symptomatology, and decrease the disease exacerbation rate. It should be emphasized, however, that not all patients are candidates for these kind of immunotherapies. Drugs and biological modifiers that induce anergy in autoreactive $T$ cells, or that have an immunosuppressive effect on cellular and humoral immunity in general, also provide potential immunotherapy approaches. Systemic or organ specific side effects of such agents, however, limit their usefulness. Immunodeviation as therapy for autoimmunity is also conceivable, but the disequilibrium between the two populations of $\mathrm{T}$ helper cells needed to decrease a Th1 autoimmune response, would also interfere with the physiological cellular immunity against microbial pathogens.

The most striking advances in immunotherapy are derived from studies in transgenic models and gene therapy. Gene therapy in particular permits the introduction of genes into antigenspecific $\mathrm{T}$ cells, thereby providing the recipient with a targeted modifying influence on the autoimmune response. Preliminary data in EAE show promising effects of latent TGF- $\beta$ transduced antigen-specific $T$ cells.

In ageing, the approach is different. The immunologic changes that occur involve many aspects of the immune system. The regulatory influence of the peripheral $T$ cell population, which in the young has a curbing effect on autoimmune responses, is diminished or lost in the aged, but the resulting increase in autoantibodies is usually harmless. Although low grade autoimmune conditions do occur in the aged population, these are mild and relatively innocuous, and hence no drastic therapeutic measures are needed. On the otherhand, the changes that occur in cellular immunity have a detrimental effect on host-defense mechanisms. "Thus, immuno-therapy would be directed towards reestablishing and stabilizing $T$ cell functions. The increase in the aged population associated with a higher susceptibility to infections, demands new approaches in immune modulation and disease prophylaxis.

\section{References}

1 Elurlich P (Proc R Soc Lond, 1900; 66:424-448).

2 Burnet FM - A modification of Jerne"s theory of antibody production using the concept of clonal selection. Aust J Sci, 1957; 20:67-69.

3 von Boehmen $\mathrm{H}$ - Positive selection of lymphocytes. Cell, 1994; 76:219-228.

4 Nossal GJV - Negative selection of lymphocytes. Cell, 1994; 76:229-239. 
5 Lo D, et al - Thymic stromal cel1 specialization and the T-cell receptor repentoire. Imnunot Res, 1997; $16: 3-$ 14.

6. Tonegawa S - Somatic generation of antibody diversity. Nature, 1983; 302:575-581.

3 Raulet DH, et al. - Developmental regulation of T-cell receptor gene expression. Nature, 1985; 314:103-107.

* Snodgrass HR, et all. - Ontogeny of the T-cell antigen receptor within the thymus. Nature, 1,985; 313:592:595.

9. Anderson $\mathrm{G}$, et al. - Cellular interactions in thymocyte development. Annu Rev Immunol, 1996; 14:73-99.

to Groettrup M, et al. - $\mathrm{T}$ cell receptor (TCR) beta chain homodimers on the surface of immature but not mature alpha, ganma, delta chair deficient T eell lines. EMBO J, 1992; 11:2735-2746.

1" Jameson SC, et al. - Positive selection of thymocytes. Anmu Rev Immunol, 1995: 13:93-126.

12 von Boehmer $\mathrm{H}$ and Kisielow $\mathrm{P}$ - Lymphocyte lineage commitment: Instruction versus selection. Cell, 1993 . $73: 207-208$.

13 Teh HS, et al. - Thymic major histocompatibility complex antigens and the $\alpha \beta$ T-cell teceptor determine the CD4/CD8 phenotype of T cells. Nature, 1988; 335:229-233.

14 Scou $B$, et all. - The generation of mature $T$ cells requires interaction of the $\alpha \beta$ T-cell receptor with major histocompatibility antigens. Nature, 1989: 338:591-593.

15 Kisielow $\mathrm{P}_{4}$ et al - Positive selection of antigen-specific $\mathrm{T}$ cells in thymus by restricting MHC molecules. Nature, 1988; 335:730-733.

16 Chan $\mathrm{SH}_{3}$ et al. - Another view of the sellective model of thymocyte selection. Cell, 1993; 73:225-236.

17 Craig $\mathrm{DB}$, et al - Evidence for a stochastic mechanism in the differentiation of mature subsets of $\mathrm{T}$ Iymphocytes. Cell, 1993; 73:237-247.

18 Janeway CA and Bottomly $\mathrm{K}$ - Signals and signs for lymphocyte responses. Cell, 1994; 76:275-285.

19. Schlossmam SF, et al. - CD antigens 1993. J Immumol, 1994; 152:1-2.

201 Freeman GJ, et al. - Cloning of B7-2: A CTLA-4 counter-receptor that stimulates human T cell proliferation. Science, 1993; 262:909-911.

2. Linsley $\mathrm{P}_{\text {n }}$ et al - Binding of the $\mathrm{B}$ cell activation antigen $\mathrm{B} 7$ to $\mathrm{CD} 28$ co-stimulates $\mathrm{T}$ cell proliferation and interleukin-2 mRNA accumulation. J Exp Med, 1991; 173,721-730.

22 Clark EA and Ledbetter JA - How B and T cells talk to each other. Nature, 1994; 237:425-428.

25 Armitage RJ, et al. - Molecular and biological characterization of a murine ligand for CD40. Nature, 1992; $357: 80-82$.

24 Hollenbaugh D, et al. - The human T cell antigen gp 39, a menber of the TNF gene family, is a ligund for the CD40 receptor: expression of a soluble form of gp 39 with B cell cosstimulatory activity. EMBO J, 1992; $114313-4321$.

25 Clark EA - CD40: A cytokine receptor in search of a ligand. Tissue Antigens, 1990; 35:33.36

3. Galy AH and Sputs H - CD 40 is functionally expressed on human thymic epithelial cells. I Immunol, 1992 ; 149:775-782.

27 Noelle RU, et al. - A 39-kDa protein on activated helper T cells binds CD40 and transduees the signal for cognate activation of B cells. Proc Natl Acad Sci, 1992; 89:6550-6554.

28 Spriggs $\mathrm{MK}$, et al. - Recombinant human $\mathrm{CD} 40$ ligand stimulates $\mathrm{B}$ cell proliferation and immunoglotbulin $\mathrm{E}$ secretion.J Exp Med, 1992, 176:1543-1550.

2 Ranheim EA and Kipps TJ - Activated T cells induce expression of B7/BB 1 on normal or leukemic $B$ cells through a CD40-dependent signal. J Exp Med, 1993; 177:925-935.

30 Jenkins $M K$, et al. - Allogeneic non- $T$ spleen cells restore the responsiveness of nornal $T$ cell clones stimulated with antigen and chemically modified antigen-presenting cells. IImmunol, 1988; 140:3324-3330

3 Webb $S$, et al. Extrathymic tolerance of mature $T$ cellss: Clonal elimination as a consequence of immunity. Cell, 1990; 63:1249-1256.

32 Schwartz RH - A cell culture for T lymphocyte clonal anergy. Science. 1990; 248:1349-1356. 
33 Beverly B, et al. - Reversal of in vitro T cell clonal anergy by IL-2 stimulation. Int Inumuol, 1992; 4:661671.

34 Rocha $\mathrm{B}$ and von Bochmer $\mathrm{H}$ - Peripheral selection of the $\mathrm{T}$ cell repertoire. Science, 1991 251:1225-1228.

yo Mosmann TR and Coffman RL - Thy and Th2 cells: different patterns of lymphokine secretion lead to different functional properties. Annu Rew Immunol, 1989: 7:145-173.

36 Rocken M and Shevach EM - Immune deviation - the third dimension of non deletional $T$ cell tolerance. Immunol Rev, 1996; 149:174-194.

37 Rocken M, et al. - A common precursor for $\mathrm{CD}^{*} \mathrm{~T}$ cells producing $\mathrm{IL}-2$ or $\mathrm{L}-4$. Immunol, 1992; 148: 103 -1036.

38 Paul WE and Seder RA - Lymiphocyte responses and cytokines. Cell, 1994:76:241-251.

39 Swain S, ct al. - CD4* T cell subsets. Lymphokine secretion of memory cells and of effector cells that develop from precursors in vitro. J Immunol. 1990; 144:1788-1.799.

4. Wu CY, el al. $-1 L-12$ induces the production of IFN-gamma by neonatal human CD4 T cells. J Immunol, 1993: $151: 1938-1949$.

41 Hsielu $\mathrm{C}-\mathrm{S}$, et al. - Development of Th1 $\mathrm{CD}^{*} \mathrm{~T}$ cells through $\mathrm{LL}-12$ produced by Listeria-induced macrophatges. Science, 1993; 260:547-549.

42. Maggi $\mathbb{E}_{\text {, et }}$ al. - Reciprocal regulatory effects of $\mathrm{FEN}-\gamma$ and $\mathrm{LL}-4$ on the in witro development of human ThI and Th2 clones. I Inumunol, 1992; 148:2142-2147.

4. Hsieh C-S, et al. - Differential regulation of Thelper phenotype development by interleukins 4 and 10 in an cap T-cell-receptor transgenic systern. Proc Nall Acad Sici, 1992; 89:6065-6069.

44 Fiorentino $D F$, et all. - Two types of mouse Thelper cell. IV. Th2 clones secrete a factor that inhibits cytokine production by Thl clones. I Exp Med, 1989; 170:2081-2095.

${ }_{45}$ Vieira $\mathrm{P}$, et al. - Isolation and expression of human cytokine synthesis inhibitory factor cDNA clones: Homology to Ebstein-Barr wirus open reading frame BCRFI. Proc Natl Acad Sci, 1991; 88:1172-1176.

46 de Waal Malefyt $\mathbb{R}$, et al. - Interleukin 10 (IL-10) and viral IL-10 strongly reduce antigen-specific human $T$ cell proliferation by diminishing the antigen-presenting capacity of monocytes via downregulation of Class II major histocompatibility complex expression. I Exp Med, 1991: 174:915-924.

47 Howard $\mathrm{M}$ and $\mathrm{O}^{\prime}$ Garra A - Biological properties of interleukin 10. Immunol Tod, 1992; 13:198-200.

48. Hochwald $\mathrm{GH}$, et al. - Transforming growth factor- $\beta \mathrm{ss}$ : endogenous immunosuppressive and antiinflammatory molecules. In: Therapeutic modulation of cytokines, edited by Henderson, B and Bodmer, MW. $1995 ; 289.315$.

19 Takahama $Y_{\text {, }}$ ef al. - Early progression of thymocytes along the CD4/CD\& developmental pathway is regulated by a subset of thymic epithelial cells expressing transforming growth factor $\beta$. J Exp Med, 1994; 179:1495-1506.

50 Shull MM, et al. - Targeted disruption of the mouse transforming growth factor- $\beta 1$ gene results in multifocal inhlammatory disease. Nature, 1992; 359:693-699.

51 Boivin GP, et al. - Animal Model. Onset and progression of pathological lesions in transforming growth factor-B I-deficient mice. Am IJ Pathol, 1995; 146:276-288.

52 Espevik T, at al. - Inhibition of cytokine production by cyclosporin A and transforming growth factor-beta. I Exp Med, 1987; 166:571-576.

53. Wath SM, et al - Transforning growth factor-beta is a potent immunosuppressive agent that inhibits IL-1dependent lymphocyte proliferation. J Immunol, 1988; 140:3026-3032.

54 Chantry $D$, et al. - Modulation of cytokine production by transforming growu factor- $\beta$. J Immunol, 1989; 142:4295-4300.

5s Espevik $T$, et al. - Regullation af interleukin-2 and interleukin-6 production from $T$ cells: involvement of interteukin-1 beta and transforming growth factor-beta. Cell Immunol, 1990; 126:47-56. 
36 Holter W, et al. - Transforming growth factor- $\beta$ inhibits $\mathrm{IL}-4$ and IFN $-\gamma$ production by stimulated human T cells. Intern Immunol, 1994; 6:469-475.

57 Abo $T$, et all. - The appearance of $T$ cells bearing self-reactive $T$ cell receptors in the liver of mice injected with bacteria. J Exp Med, 1991: 174:417-424.

3s Ohteki $T$, ef al. - Age-dependent increase of extrathymic $\mathrm{T}$ eells in the liver and their appearance in the periphery of older mice. I Immunol 1992; 149:1562-1570.

59. Miller RA - Aging and Immune Function. Int Rev Cytol, 1991; 124:187-215.

6 Nagell $\mathrm{EE}$, et al. - Monoclonal antibody analysis of T-lynaphocyte subsets in young and aged adults. Imunumol Cornm, 1983; 12:223-237.

of Fagnoni FF, et al. - Expansion of cytotoxic $\mathrm{CD}^{*} \mathrm{CD} 28$ " T cells in thealthy ageing people. Inmunot, 1996: $88: 501 \% 507$.

62 Effros RR, et all. - Decline in CD28 ${ }^{+} \mathrm{T}$ cells in centenerians and in long-term $\mathrm{T}$ cell cultures: a possible cause for both in wivo and in vitro immunosenescence. Exp Gerontol, 1994; 29:601-609.

6.3 Warren RP, et al. - Age-related changes in $C D 45 \mathrm{R}^{+}$and $\mathrm{CD}$ w29* helper $\mathrm{T}$ cells in human subjects. Aging: Immunol Infect Dis, 1990; 2:91-94.

64 DePaoli P, et al. - Age-related changes in human lymphocyte subsets: progressive reduction of the CD4 CD45R (suppressor inducer) population. Clin Immunol Immunopath, 1988; 48:290-296.

${ }^{25}$ Cossarizza $\mathrm{A}$, et al. - CD45 isoforms expression on $\mathrm{CD} 4^{*}$ and $C D 8^{*} \mathrm{~T}$ cells throughout life, from newborns to centenerians: implications for T cell memory. Mech Ageing Dev, 1996; 86:173-195.

6.5 Shearer GM - Th1/Th2 changes in aging. Mech Aging Dewelop, 1997; 94,: 1-5.

6. Castle S, et al. - Evidence of enhanced type 2 immune response and impaired apregulation of a type 1 response in frail elderly nursing home residents. Mech Aging Develop, 1997; 94:7-16.

68 Antonaci, $S_{4}$ et all. - Immunoregulation in aging. Diagn Clin Immunol, 1987; 5:55-61.

69 Talor $\mathrm{E}$ and Rose NR - Hypothesis: the aging paradox and autoimmume disease. Autoimmunity , 1991: 8:245 249.

To Wendell Richmond $\mathrm{G}$ and $\mathrm{Yu}$ B-H. Autoantibodies, autoimmune diseases, and vasculitis in the aged. Immunol Allergy Clin North Am, 1993; 13:647-671.

"Phelouzat M-A, et al. - Susceptibility to apoptosis of T lymphocytes from elderly humans is associated with increased in vivo expression of functional Fas receptors. Mech Aging Develop, 1997; 96:35-46.

72 Hendon FJ, et al. - Increased apoptosis of CD45RO T cells with aging. Mech Aging Develop i 1997 ; 94:123-134.

7 Shigekazu N and Golstein $\mathbb{P}$. The Fas death factor. Science, 1995; 267:1449.1456.

4 Zarnvill $\mathrm{SS}$, et al. - T-cell cllones specific for myelin basic protein induce chronic relapsing paralysis and demyelination. Nalure, 1985; 317:355-358.

75 Zamvil $S S$ and Steinman $L_{*}$. The T lymphocyte in experimental allergic encephalomyelitis. Annu Rev Immunol. 1990; 8:579-621.

76 Segal BS, et al. - An interleukin (IL)-10/ LL-12 Inmunoregulatory circuit controls susceptibility to autoimunune disease. J Exp Med, 1998; 187:537-546.

"Krakowsk $M$ ard $O$ wens $T$ - Interferon- $\gamma$ confers resistance to experimental allergic encephalomyelitis. Eur J Immunol, 1996; 26:1641-1646.

Fis LaFalle JJ, et al. - Myelin basic protein-specific T helper 2 (Th2) cells cause Experimental Autoimmune Encephalomyelitis in immunodeficient hosts rather than protect thern from the disease. I Exp Med, 1997; 186:307-312.

79 Koh D-R, et al - Experimental allergic encephalomyelitis (EAE) in mice lacking CD4 ${ }^{*} \mathrm{~T}$ cells. Eur $I$ Immunol, 1994:24:2250-2253. 



\section{Chapter \\ 2}

\section{Age-related loss of immunoregulatory function in peripheral blood CD8 $\mathrm{T}$ cells}

GM Crisi**, Chen LZ, Huang C and Thorbecke GJ

Dept. of Pathology and Kaplan Comprehensive Cancer Center, New York University School of Medicine, New York, NY 10016 


\section{Summary}

$\mathrm{CD} 8^{*} \mathrm{~T}$ cells from young individuals become inhibitory for the ( $\mathrm{S}$. aureus $+\mathbb{L}-2$ ) indue differentiation of autologous $\mathrm{B}$ cells into Ig secreting cells (ISC) after exposure to pokewer mitogen, dimaprit or intracellular CAMP raising agents, such as forskolin or dibutyryl cAMP. the present study this immunoregulatory activity was found to be lacking in $\mathrm{CD} 8^{+} \mathrm{T}$ cells fro PBL of aged ( $>67$ years old) subjects. Splenic $\mathrm{CD} 8^{+} \mathrm{T}$ cells from most individuals examine including some aged subjects, exhibited this activity. While an age related decrease in the CD8 ${ }^{+}$ cell subset, primarily in the virgin $\mathrm{CD} 8^{+} \mathrm{T}$ cells in PBL was detected, this decrease was $\mathrm{n}$ sufficient to explain a total absence of activity. There was no age related decrease in CAM upregulation by forskolin or dimaprit in peripheral blood $T$ cells. However, whereas $\mathrm{PW}$ ] induced a highly significant increase in mRNA for TGF- $\beta$ in $T$ cells from young individuals, $\mathrm{I}$ such increase could be detected in $T$ cells from aged subjects. It is suggested that the decrease immunoregulatory activity in PBL from the elderly may at least in part be due to a decrease TGF- $\beta$ production.

\section{Introduction}

It is known that PWM induces immunoregulatory activity in $\mathrm{CD} 8^{+} \mathrm{T}$ cells from PBL of your individuals resulting in down regulation of $\mathrm{Ig}$ secretion in cocultured autologous B cells. This most clearly demonstrated when the B cells are stimulated in a T-independent fashion, such : can be achieved with $S A C+I L-2^{1}$. In previous studies ${ }^{2}$ we have found that stimulation histamine type 2 receptors (H2-R) with dimaprit has a similar effect on $\mathrm{CDB}^{+} \mathrm{T}$ cells, inducin suppressor activity on the differentiation of $(\mathrm{SAC}+\mathrm{LL}-2)$ stimulated $\mathrm{B}$ cells after a $3 \mathrm{~h}$ exposure dimaprit. In addition, it was found that cimetidine, an H2-R blocking agent, prevents the PWI mediated activation of $\mathrm{CD}^{+} \mathrm{T}$ cell suppression ${ }^{2}$. Considering previous demonstrations th stimulation of $\mathrm{T}$ cells wia the H2-R leads to increases in intracellular $\mathrm{CAMP}^{3}$ and that $\mathrm{PWI}$ induces increases in intracellular cAMP in human lymphocytes ${ }^{4}$, and our own observation that a inhibitor of cAMP kinase, HA1004, prevents the induction of immunoregulatory activity in CD8 $\mathrm{T}$ cells by PWM or dimaprit ${ }^{2}$, it seems that this activity in the $\mathrm{T}$ cells is due to increases $\mathrm{i}$ intracellular CAMP. Recent studies on immunoregulatory $T$ cells frequently attribute thes activities to enhanced production of immunosuppressive cytokines, such as TGF- $\beta$ by such cell (reviewed in Hochwald et al..$^{5}$ ). In our previous studies, we obtained suggestive evidence that, * least in some of these experiments, the suppression was exerted by TGF- $\beta$, possibly produced i latent form and activated on the B-cell surface ${ }^{2}$. This was in agreement with the known inhibitio by PF4 of other TGF- $\beta$ mediated effects, such as the angiogenic effect ${ }^{6}$.

A decrease in immunoregulatory effects by $\mathrm{CDB}^{+} \mathrm{T}$ cells from aged as compared to youn animals has been observed in several studies (reviewed by Gottesman ${ }^{7}$ ), as in the function activity of $\mathrm{CD}^{+}$suppressor $\mathrm{T}$ cells in humans ${ }^{8.9}$. Con- $\mathrm{A}$ induced, $\mathrm{T}$-cell mediated suppression $\mathrm{c}$ Ig secretion was found to decrease with age ${ }^{10,11}$, while studies using PWM as an inducer o immunoregulatory $\mathrm{T}$ cell function showed either a decrease or an increase in aged individuals ${ }^{12,1}$ 
Few if any studies on the abilities of $T$ cells from aged individuals with respect to TGF $\beta$ production and/or CAMP upregulation in response to stimulation have been reported.

The purpose of the present study was to investigate whether $C D 8^{+} \mathrm{T}$ cells from aged donors, after exposure to PWM or dimaprit, had an equally suppressive effect on autologous $(S A C+\llbracket-2)$ activated $B$ cells as do $\mathrm{CD} 8^{+} \mathrm{T}$ cells from young donors. We enumerated CD8 ${ }^{*} \mathrm{~T}$ cell subsets in the peripheral blood and spleen from young and aged individuals and evaluated the functional capacity of these cells to influence $T$-independent polyclonally activated $B$ cell differentiation. We further investigated whether agents, known to cause an increase in intracellular cAMP in lymphocytes, would equally activate $\mathrm{CD} 8^{+}$suppressor cells in PBL from aged as from young individuals. The data to be reported indicate that activated $C D 8^{+} \mathrm{T}$ cells from PBL of aged subjects are defective in immunoregulatory function, whether induced by PWM or cAMP upregulating agents, and that this defect is paralleled by an age-related decrease in PWM induced TGF- $\beta$ mRNA production, but not by a defective cAMP response.

\section{Materials and Methods}

\section{Reagents}

RPMI-1640 was purchased from Gibco BRL (Grand Island, NY); fetal bovine serum (FBS), Lglutamine, penicillin-streptomycin and HBSS from BIO-Whittaker Bioproducts (Walkersville, MD); 2-aminoethylisothiouronium bromidle (AET) and mitomycin-C from Sigma Chemical Co. (St. Louis, MO); nylon wool fiber from Polysciences Inc. (Warrington, PA); pokeweed mitogen (PWM) and guinea pig serum from GIBCO BRL; formalinized Cowan 1 strain of Staphylococcus aureus (SAC) from Calbiochem-Behring Corp. (La Jolla, CA); S. aureus protein A from Pharmacia BioProcess (Uppsala, Sweden); recombinant human $\mathrm{IL}-2$ (rLl-2) was a gift from Hoffman-La Roche (Nutley, NJ); dimaprit was a gift from SmithKline and Beecham (Philadelphia, PA). The nonhydrolyzable cyclic AMP (cAMP) analogues, chloro- and bromophenylthio-CAMP, forskolin, dibutyryl-cAMP, and the cAMP kinase inhibitor, HA 1004, were purchased from Sigma Chemicall Co. (St. Louis, MO). The cAMP Radioimmunoassay (RLA) Kit was purchased from Biomedical Technologies Inc. (Stoughton, MA). The culture medium (CM) used was RPMI-1640 supplemented with $10 \% \mathrm{FBS}, 50 \mathrm{U} / \mathrm{ml}$ penicillin $\mathrm{G}$ and $100 \mu \mathrm{g} / \mathrm{ml}$ streptomycin.

\section{Antibodies}

The anti-CD3 (IgG2a mAb 64.1; ${ }^{14}$ ) was a generous gift from Dr. E. Viteta (U. of Texas Southwestern Med. Center, Dallas). The anti-CD4 (OKT4), anti-CD1 Ib (OKM1) and anti-CD57 (HNK1) monoclonal antibodies (mAb) were grown as ascites in BALB/c mice from the cell lines purchased from ATCC (Rockville $M D$ ). The HNK $1 \mathrm{mAb}$ was purified from ascites by adherence 10 and elution from a protein $A$ column and then coupled to biotin. The anti-NK cell marker, B73 1.I mAb, was a kind gift from Dr. Bice Perussia (Thomas Jefferson University, Philadelphia, PA). Phycoerythrin (PE) labeled anti-CD3, anti-CD4 and anti-CD8 were purchased from Olympus Co. (Lake Success, NY); fluorescein (FTTC) labeled anti-CD14, anti-CDS6, anti- 
CD1 $1 b$, anti-CD28 and anti-CD19 from ExAlpha Co. (Boston, MA) and FTC labeled anti CD45RO (UCHL-1) from Dako Corp. (Carpinteria, CA). Streptavidin-RED 613 was purchase from GIBCO BRL.

\section{Subjects}

Peripheral blood was obtained from healthy young subjects ( $14 \mathrm{M}$ and $10 \mathrm{~F}$ ) between 21 and 3 . years of age (27.8 \pm 5.2 ), and elderly wolunteers ( $5 \mathrm{M}$ and $13 \mathrm{~F}$ ) between 68 and 86 years of ag (76.6 \pm 5.8 ). All donors were free of diseases affecting the immune system, insulin dependen diabetes, cancer or infections. None were taking medication currently known to alter the immun responsiveness.

\section{Spleen samples}

Fresh human spleen specimens were obtained from the surgical pathology laboratories of Tiscl and Bellevue Hospital. Table I describes the profile of patients who underwent splenectomy. Thi splenocytes were obtained by teasing the spleen specimen through a coarse screen. The obtaine cell suspension was incubated with 1:500 DNase at $37^{\circ} \mathrm{C}$ for $10-15$ min and passed through a cel strainer. The cells were subsequently washed, layered over Lymphoprep (Nycomed Pharma, Oslo Norway, ${ }^{15}$ ) and the obtained interphase cells were frozen in liquid $\mathrm{N}_{2}$ until further use.

\section{Table 1}

\section{Profile of patients who underwent splenectomy}

\begin{tabular}{llll}
\hline Age & Sex & Race* & Indication for Surgery/Diagnosis \\
\hline 28 & F & C & Splenocytosis, splenomegaly and cholecystitis \\
28 & F & C & Acute and chronic pancreatitis \\
35 & F & A & Hereditary spherocytosis \\
39 & F & C & Pancreatic pseudocyst \\
45 & F & C & Pancreatic neoplasm and spleen amyloidosis \\
49 & M & C & Pancreatic pseudocyst \\
67 & F & C & Rupture with subcapsular hematoma following resection of \\
& & & retroperitoneal liposarcoma \\
68 & F & C & Islet cell carcinoma, spleen free of tumor \\
69 & F & C & Anemia with splenic congestion and hemosiderosis \\
78 & M & C & Secondary renal tubular adenocarcinoma of pancreas
\end{tabular}

* C. Catucasian; A: Asian 


\section{Lymphocyte purification and fractionation}

Peripheral blood mononuclear cells (PBMC) were isolated from heparinized venous blood by gradient centrifugation over Lymphoprep. PBMC and splenocytes were fractionated into $T$ and $B$ cells by the AET-treated sheep red blood cell rosetting method (AET-SRBC) ${ }^{16}$. Subsequently, the rosetting and nonrosetting populations were separated by gradient centrifugation. The nonrosetting B cells obtained from the interface were again rosetted. Spleen B cells from aged and young individuals contained $>83 \%$ and $>74 \%$ CD $19^{+}$cells, respectively. Peripheral blood B cells from aged and young individuals contained $>50 \% \mathrm{CD} 19^{+}$cells. The sedimented rosetteforming cells were briefly treated with $\mathrm{H}_{2} \mathrm{O}$ to lyse the SRBC, washed and then passed over a cell strainer to remove cell debris. In some experiments the $T$ and $B$ cells were fractionated by the nylon wool method. Briefly, $0.6 \mathrm{gm}$ nylon wool were introduced in a $12 \mathrm{cc}$ syringe and autoclaved. The nylon wool syringe was impregnated with $\mathrm{CM}$ and incubated at $37^{\circ} \mathrm{C}$ for $1 \mathrm{~h}$, after which PBMC or splenocytes were added to the column at a concentration of $1-2 \times 10^{7}$. After $1 \mathrm{~h}$ incubation at $37^{\circ} \mathrm{C}$ the nonadherent $\mathrm{T}$ cells were eluted. The adherent $\mathrm{B}$ cells and monocytes were recovered by teasing the nylon wool. When comparing the two methods of $T-B$ cell fractionation in the same individual, there was no observable difference in both the cell purity obtained and in the functional activity of the cells. Where needed, $\mathrm{T}$ cells were pretreated with mitomycin C: $5 \times 10^{6} / \mathrm{ml}$ unfractionated or enriched $\mathrm{CD}^{+} \mathrm{T}$ cells were incubated for 45 min at $37^{\circ} \mathrm{C}$ with $40 \mu \mathrm{g} / \mathrm{ml}$ mitomycin $\mathrm{C}$, then washed extensively before culture.

\section{Isolation of $\mathrm{CD8}^{+} \mathrm{T}$ cell subsets}

$\mathrm{CD}^{+} \mathrm{T}$ cells were isolated by a negative selection indirect panning technique ${ }^{17}$. Briefly, T cells were incubated 30 to $60 \mathrm{~min}$ on ice with saturating concentrations of anti-CD4 $\mathrm{mAb}$. In some experiments $\mathrm{T}$ cells were also incubated with anti-CD1lb mAb. After washing, the cells were added to goat anti-mouse Ig-coated bacteriological grade Petri dishes. After $1 \mathrm{~h}$ incubation at $4^{\circ} \mathrm{C}$, non-adherent cells were gently removed. In some cases the panning was repeated. The resulting $\mathrm{CD}^{+}$enriched $\mathrm{T}$ cells were $50-80 \% \mathrm{CD}^{+}$as shown by staining with PE-conjugated anti-CD8.

\section{T and B cell cocultures for generation of Immunoglobulin Secreting Cells (ISC)}

$\mathrm{CD} 8^{+} \mathrm{T}$ cell subsets were pre-incubated with $50 \mathrm{mM}$ forskolin for one $\mathrm{h}, 5 \times 10^{-4} \mathrm{M}$ dimaprit, 10 mM cAMP analogues or $10 \mathrm{mM}$ dibutyryl- cAMP for $3 \mathrm{~h}$. After incubation, the cells were washed extensively before further culture. Cells incubated with dimaprit will be referred to as $\mathrm{CD} 8^{+} \mathrm{T}_{\text {dim }}$ throughout the text. PWM activated $\mathrm{CD}^{+} \mathrm{T}$ cells were always pretreated with mitomycin $\mathrm{C}$. These cells will be referred to as $\mathrm{CD} 8^{+} \mathrm{T}_{\mathrm{m}}$. Cells were cultured in $\mathrm{U}$-bottomed $96-$ well plates (Becton Dickinson, Lincoln Park, NJ). Routinely, nine replicate cultures were set up to a volume of $200 \mu \mathrm{\mu l} /$ well. B cells $\left(2.5 \times 10^{5} / \mathrm{ml}\right)$ were cultured alone or with $10^{6} / \mathrm{ml} \mathrm{CD8} 8^{+} \mathrm{Tm}$, $\mathrm{CD} 8{ }^{+} \mathrm{T}$ dim or $\mathrm{CD}^{+} \mathrm{T}$ cells that had been pre-incubated with the $\mathrm{CAMP}$ upregulating agents. To the $\mathrm{CM}$ were added $100 \mathrm{U} / \mathrm{ml} \mathrm{rLL}-2$ and $1: 60,000$ SAC. $20 \mathrm{mg} / \mathrm{ml}$ PWM was added to the cultures where indicated. The cells were incubated for 5 days at $37^{\circ} \mathrm{C}$. At the end of the incubation, cells

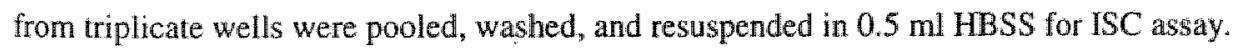




\section{Detection of ISC}

$\mathrm{ISC}$ were detected with a reverse hemolytic plaque assay that made use of $\mathrm{S}$. aureus protein $\mathrm{A}$ coated SRBC ${ }^{18}$. Plaques were developed with a $1 / 30$ diluted rabbit anti-human Ig purified in the lab. The complement source was a $1: 18$ dilution of guinea pig serum that had previously been absorbed with SRBC. The mean numbers of $1 \mathrm{SC}$ culture \pm SD of three or more replicate samples were used to determine the significance of differences between groups within each experiment.

\section{Extraction and measurement of cAMP}

Suspensions were made of $\mathrm{T}$ cells from young and aged donors, and incubated for $3 \mathrm{hr}$ in the presence or absence (control) of $5 \times 10^{-4} \mathrm{M}$ dimaprit, or for 4,15 and $60 \mathrm{~min}$ in the presence or absence of $50 \mathrm{mM}$ forskolin. After the incubation, the cells were washed in cold DPBS Ca ${ }^{2 *}$ and $\mathrm{Mg}^{2+}$ free, transferred into polypropylene tubes at a concentration of $2 \times 10^{6}$ cells per tube, spun and resuspended in $0.5 \mathrm{ml}$ of $0.05 \mathrm{M} \mathrm{HCl}$. After boiling for 3 minutes, the samples were cooled in dry ice and lyophilized for 5 to $18 \mathrm{~h}$. The obtained pellet was reconstituted with $0.05 \mathrm{M} \mathrm{Na}$ acetate buffer and stored at $-20^{\circ} \mathrm{C}$. CAMP levels were measured using a competitive protein binding ${ }^{125}$ I-labeled cAMP RLA Kit ${ }^{19}$.

\section{Reverse transcription and competitive PCR for quantitation of TGF- $\beta$ mRNA}

Total RNA was extracted from T cell samples from 5 young and 6 aged individuals, cultured for 24 h either with or without PWM, using the "RNA Stat-60" kit (Tel-Test, Inc., Friendwood, TX) according to the manufacturer's directions. Three $\mu \mathrm{g}$ of RNA from each sample were subjected to first strand CDNA synthesis in a $20 \mu \mathrm{l}$ reaction volume, following the protocol for the "Superscript first strand cDNA synthesis" kit (Gibco BRL, Life Technologies, Grand Island, NY). The cDNA products were diluted 10 and 100 fold, and $1 \mu$ of the undiluted and diluted samples were used as templates for TGF- $\beta 1$, in competition with $10^{-21}$ M human TGF- $\beta$ mimic (Clontech Labs. Inc., Pallo Alto, CA), in a $50 \mu$ PCR reaction. The primer sequences used were as follows: 5' upstream primer, 5' GCC CTG GAC ACC AAC TAT TGC T 3', and 3' downstream primer, 5" AG GCT CCA AAT GTA GGG GCA GG 3", as suggested by Clontech. The final reaction products $(15 \mu \mathrm{l}$ amples) were run on a $2 \%$ ethidium bromide $(0.5 \mu \mathrm{g} / \mathrm{ml})$ containing agarose gel, and photographed under UV light. The bands on the picture were scanned and quantitated using Kodak digital sofiware. Ratios of sample over competitive mimic band areas were plotted against sample dilution, allowing a relative estimate of TGF- $\beta$ mRNA quantities.

\section{Cell surface antigen staining}

Unfractionated PBMC and total spleen lymphocytes from young and aged donors were analyzed for surface antigens using directly labeled mAb. Single, dual and triple stainings were done with FITC, PE and/or biotin labeled $\mathrm{mAb}$ followed by streptavidin-R613. Analysis was done with a FACScan flow cytometer (Becton Dickinson). 


\section{Results}

Effect of age on the suppressive activity of PWM- and Dimaprit-activated $\mathrm{CD}^{+} \mathrm{T}$ cells on ISC formation

To studly the age-related changes in the immunoregulatory activity of $\mathrm{CDB}^{+} \mathrm{T}$ cells on T-cellindependent $\mathrm{B}$ cell activation, we used the in vitro model described by Hirohata et al. ${ }^{20}$. B cells from aged and young donors were cultured with $\mathrm{SAC}+\mathbb{I L}-2$ alone or in the presence of untreated or mitomycin-treated $\mathrm{CD} 8^{+} \mathrm{T}$ cells. As in previous findings ${ }^{2}$. PWM activated mitomycin-treated $\mathrm{CD}^{*} \mathrm{~T}$ cells from PBL from young donors caused a significant decrease of the ISC response of co-cultured activated B cells (Table 2), whereas B cells alone were not affected by the addition of PWM. In contrast, such a suppressive activity of PWM-activated CD8 ${ }^{+} \mathrm{Tm}$ on the ISC response was not observed with PBL from any of the aged individuals studied. Sirnilar to PWM, $5 \times 10^{-4}$ $M$ dimaprit suppressed the $\mathrm{B}$ cell response to ( $\mathrm{SAC}+\mathbb{I L}-2$ ) in the presence, but not in the absence, of $\mathrm{CD}^{*} \mathrm{~T}$ cells in 11 of the 12 experiments with cells from young, but in none of the experiments with cells from aged individuals. Thus, these findings indicate that PWM or dimaprit activated PBL CD8 ${ }^{+} \mathrm{T}$ cells from aged donors lack the immunoregulatory activity on (Sac + IL-2) activated autologous $\mathrm{B}$ that is observed in $\mathrm{CD} 8^{+} \mathrm{T}$ cells from young individuals.

Table 2

Effect of PWM- or dimaprit-treated $\mathrm{CDB}^{+} \mathrm{T}$ cells from the PBL of young and aged individuals on Ig secretion by autologous $B$ cells

Additions to cultures \% of $\mathrm{B}$ Cell Alone Response in $\left(\mathrm{B}+\mathrm{CD} 8^{+} \mathrm{T}\right)$ Cells From:

\begin{tabular}{lllll}
\hline & Young Individuals & $p^{* * *}$ & Aged Individuals & $p^{* * *}$ \\
\hline Pokeweed Mit. $^{\$}$ & $55.5 \pm 7.0(\mathrm{n}=18)$ & $<0.001$ & $90.0 \pm 17.4(\mathrm{n}=12)$ & $\mathrm{NS}$ \\
Dimaprit $^{\$}$ & $57.9 \pm 10.8(\mathrm{n}=12)$ & $<0.001$ & $97.5 \pm 16.2(\mathrm{n}=5)$ & $\mathrm{NS}$ \\
Forkkolin & $53.7 \pm 12.2(\mathrm{n}=5)$ & 0.01 & $81.3 \pm 18.7(\mathrm{n}=3)$ & $\mathrm{NS}$ \\
CAMP analog & $50.0 \pm 19.0(\mathrm{n}=3)$ & 0.02 & $102.4 \pm 4.0(\mathrm{n}=5)$ & $\mathrm{NS}$ \\
\hline
\end{tabular}

* The CAMP analogues ased wete the nonhydrolyzable CAMP analogues: chloro- and bromo-phumblhio-cAMP, added at $0.01 \mathrm{mM}$. Forskolin was used at $0.05 \mathrm{mM}$ and dimaprit an $0.5 \mathrm{~m}$ M. Preincubation of the $T$ wells with these reagents was for $1 \mathrm{~h}$ (forskolin) and $3 \mathrm{~h}$ (other reagents) at $37^{\circ} \mathrm{C}$, wher which the cells were washed and combined with $B$ cells $+S A C+$ IL -2 .

* Two experiments in each of these groups were performed with CD8* T alls from which the $11 \mathrm{~b}^{*}$ and $\mathrm{CDS} 7^{*}$ cells had been remowed with entirely comparable results. They were therefore combined with the other result in this table.

* The $p$ walues for groups of individwals are for the comparison between the Ig secreting cell (1SC) numbers

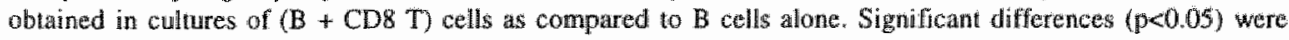
obtained for $16 / 18$ of the individual PWM expts. $11 / 22$ dimaprit expts, 5/5 forskolin axpts and $2 / 3$ CAMPanag expts with PBL from young subjects and for nome of the expts with PBL from aged subjectg.

fo0: values of $1 S C$ cullume were 1053 \& 491 for PBL from aged as comparedil to $1246 \pm 412$ for PBL from young subjects. 
A comparison of the relative activities of anti-CD3 activated mitomycin-treated unfractionated $T$ cells from aged and young individuals in causing the proliferation of $B$ cells was also made (not shown). We found that $\mathrm{T}$ cells from $50 \%$ of the aged individuals functioned suboptimally. However, there was no difference between young and old in these proliferative responses that could be atributed to an intrinsic defect in the B cells from aged individuals. Moreover, as seen in the footnote to Table 2, the numbers of ISC induced in T-cell independent fashion, i.e. by exposure of $B$ cells to $S A C+I L-2$, did not show a significant difference between young and old.

\section{Table 3}

Effect of PWM- and Dimaprit-activated splenic $\mathrm{CD}^{+} \mathrm{T}$ cells from young and aged subjects on Ig secretion by autologous $B$ cells

\begin{tabular}{|c|c|c|c|c|c|c|c|}
\hline \multirow{2}{*}{$\begin{array}{l}\text { Spleen } \\
\text { Donor } \\
\text { \# } \\
\end{array}$} & \multirow[t]{2}{*}{ Sex } & \multirow[t]{2}{*}{ Age } & \multirow{2}{*}{$\begin{array}{l}\text { B cells } \\
\text { Alone ** } \\
=100 \%\end{array}$} & \multicolumn{4}{|c|}{ Percentage of B Cell Alone ISC Response In: } \\
\hline & & & & $\begin{array}{l}\text { B + PWM-Act } \\
\text { CD8 T Cells (n) }\end{array}$ & $\begin{array}{l}\text { p vs B } \\
\text { Alone }\end{array}$ & $\begin{array}{c}\text { B + DIM-Act } \\
\text { CD8 T Cells (n) }\end{array}$ & $\begin{array}{l}\text { p vs B } \\
\text { Alone }\end{array}$ \\
\hline $1^{\text {H* }}$ & $\mathrm{F}$ & 28 & 7040 & $24 \pm 1.8(3)$ & 0.0009 & $73 \pm 11.6(3)$ & 0.07 \\
\hline 2 & $\mathrm{~F}$ & 28 & 1177 & $43 \pm 1.3(3)$ & 0.0011 & $53 \pm 15.5(3)$ & 0.014 \\
\hline 3 & $\mathbb{F}$ & 35 & 449 & $55 \pm 8.5(3)$ & 0.0027 & ND & \\
\hline 4 & $\mathrm{~F}$ & 39 & 1533 & $24 \pm 1.7(3)$ & $<0.00001$ & ND & \\
\hline 5 & $F$ & 45 & 8427 & $3 \pm 0.3(3)$ & $<0.00001$ & $15 \pm 1.9(3)$ & $<0.0001$ \\
\hline 6* & M & 49 & 1680 & $68 \pm 19.2(6)$ & 0.009 & $58 \pm 8.4(6)$ & 0.0001 \\
\hline $7 *$ & $\mathrm{~F}$ & 67 & 2613 & $21 \pm 13.6(3)$ & 0.0012 & $53 \pm 8.0(3)$ & 0.0006 \\
\hline $8^{*}$ & $\Gamma^{*}$ & 68 & 2031 & $36 \pm 17.0(9)$ & 0.0001 & $68 \pm 13.0(3)$ & 0.034 \\
\hline 9 & $\mathrm{~F}$ & 69 & 1620 & $\mathrm{ND}$ & & $57 \pm 16.2(3)$ & 0.01 \\
\hline 10 & M & 78 & 1463 & $86 \pm 22.0(6)$ & NS & $71 \pm 16.0(6)$ & NS \\
\hline
\end{tabular}

* The inhibition caused by PWM activated $\mathrm{CD} 8^{+} \mathrm{T}$ cells from which the CDIIb cells had been removed was also tested wih these spleen cells. No significant suppression was obtained. The percentages of the responses obtained in $B$ cells alono were:

Patient 1 1: 120\%; Patient \#6:88\%; Patient \#7: 109\%; Patient \#8: $94 \%$.

* The percentages of ISC seen in cultures of B cells alone obtained in (B+ CD8* T) cells without PWM or dimaprit ranged from 102 to 153 \%

It was of interest to determine whether $\mathrm{T}$ cells derived from the spleen would exhibit a similar immunoregulatory effect on the ISC response of Sac $+\mathbb{L}-2$ activated B cells as that seen with PBL T cells, and if so whether this was also diminished with age. Autologous splenic B cells 
from young and aged donors were, therefore, cultured in the presence or absence of PWM- or dimaprit-activated splenic $C D 8^{*} \mathrm{~T}$ cells. Table 3 represents the individual experiments done with spleen cells derived from the donors listed in Table 1. As in peripheral blood, young splenic CD ${ }^{+}$ T cells exhibited an immunoregulatory effect on the $(\mathrm{SAC}+1 \mathrm{~L}-2)$ induced $\mathrm{B}$ cell differentiation. Although the numbers of individual spleen samples examined is too low to allow any conclusions as to the effect of age, the results suggest that splenic CD8* $\mathrm{T}$ cells retain some immunoregulatory activity with advancing age.As CDIIb and $\mathrm{CDST}^{+} \mathrm{T}$ cells have been reported to increase in the aged, we asked whether depleting such $T$ cell subsets would alter the immunoregulatory activity of the $\mathrm{CD}^{*} \mathrm{~T}$ cells. Two experiments were done with PBL from both young and aged donors in which the $\mathrm{CD} 11 \mathrm{~b}^{+}$and $\mathrm{CD} 57^{+} \mathrm{T}$ cells were removed prior to assay of immunoregulatory activity. The results were entirely comparable to those obtained with unfractionated CD8 ${ }^{+} \mathrm{T}$ cells (see footnote Table 2).

Surprisingly, however, when the CD11 $\mathrm{b}^{*} \mathrm{~T}$ cells were depleted from the splenic CD8* $\mathrm{T}$ cells, no significant suppression of the ISC response was obtained, both in cultures with cells from aged and young indiwiduals (see footnote Table 3). The fact that removal of $\mathrm{CD} 11 \mathrm{~b}^{+} \mathrm{T}$ cells from the spleen, but not from PBL, altered the degree of suppression of the ISC response suggests that different subsets of $\mathrm{T}$ cells might be responsible for this immunoregulatory function in $\mathrm{CD} 8^{+} \mathrm{T}$ cells from different compartments.

\section{Effect of cAMP upregulating agents on immunoregulating activity of $\mathrm{CD}^{+} \mathrm{T}$ cells from aged and young individuals}

Ageing could lead to a decrease in the generation of intracellular signals, which then could alter the functional activity of the T cells. To evaluate the role of intracellular CAMP in mediating the immunoregulatory effect of $\mathrm{CD} 8^{*} \mathrm{~T}$ cells incubated with dimaprit, we determined whether the protein kinase A inhibitor, HA1004, would inhibit the induction of suppressor activity in cultures with $T$ and $B$ cells from young individuals. The inhibitor was added $0.5 \mathrm{hr}$ prior to dimaprit. After incubation, the $\mathrm{T}$ cells were thoroughly washed before addition to the $\mathrm{B}$ cell cultures. When incubated with dimaprit alone the CD8 ${ }^{*} \mathrm{~T}$ cells caused a significant suppression of the ISC response, whereas cells incubated with both HAl004 and dimaprit did not (Table 4). Similarly, when $\mathrm{CD}^{+} \mathrm{T}$ cells from young subjects were incubated, prior to addition to autologous $\mathrm{B}$ cells, with known cAMP-upregulating agents, such as forskolin (0.05 $\mathrm{mM})$, dibutyryl-cAMP (0.01 mM) and the CAMP nonhydrolyzable analogs chloro-and bromo-phenylthio-CAMP $(0.01 \mathrm{mM})$, significant suppression of the ISC response was seen (Table 4). In the presence of HA1004 such suppression was also reversed.

We next compared the immunoregulatory activities of PBL CD8 $\mathrm{T}$ cells from young and aged donors after preincubation with known cAMP upregulating agents, such as forskolin $(0.05 \mathrm{mM})$ and the cAMP nonhydrolyzable analogs chloro-and bromo-phenylthio $\mathrm{AMP}$ (0.01 $\mathrm{mM})$. The results in Table 2 show that $\mathrm{CD} 8^{+} \mathrm{T}$ cells from aged donors incubated with forskolin or chloroand bromo-phenylthio-cAMP exhibited no significant immunoregulatory activity on the (SAC + IL-2) activated B cell ISC response, whereas such activity was clearly present in similarly incubated $\mathrm{CD}^{*} \mathrm{~T}$ cells from young individuals. 
Table 4

Reversal by HA1004 of CD8 ${ }^{+}$PBL $\mathrm{T}$ cell-induced suppression of ISC development in vitro

\begin{tabular}{lllll}
\hline Suppression-Inducing Agent & \multicolumn{2}{l}{ \% of Response in B Cells Alone } & & \\
& $\mathrm{B}+\mathrm{CD} 8^{*} \mathrm{~T}$ & $\mathrm{~B}+\mathrm{CD} 88^{*} \mathrm{~T}+\mathrm{HA1004}$ & $(\mathrm{n})^{*}$ & $\mathrm{p}^{*}$ \\
\hline Dimaprit & $45.1 \pm 3.7$ & $77.8 \pm 2.8$ & $(3)$ & 0.0002 \\
Forskolin & 67.3 & 104 & $(1)$ & $*$ \\
Dibut-cAMP or cAMP-analogs & $54.2 \pm 20.6$ & $98.5 \pm 34.8$ & $(5)$ & 0.04 \\
\hline
\end{tabular}

* The p values for groups of individuals are for the comparison between the $15 C$ numbers obtained in cultures of $(\mathrm{B}+\mathrm{CD} 8 \mathrm{~T})$ wells with and without HA.1004, both in the presence of the respective suppression-inducing agent. $\mathrm{n}=\mathrm{number}$ of individual experiments included.

"The p walue for the comparison of groups with this single expl. with forskolin was $\mathrm{p}=0.024$.

To directly look for a possible age-related defect in CAMP upregulation, the cAMP levels in T cells from young and aged donors were measured after incubation of the cells with forskolin. Figures $1 \mathrm{a}$ and $\mathrm{lb}$ show the CAMP measurements obtained after 4,15 and $60 \mathrm{~min}$. incubation of unfractionated $T$ cells with forskolin. In cells from both aged and young forskolin induced an increase in CAMP within $4 \mathrm{~min}$. of incubation. The CAMP levels peaked at 15 min. and then decreased, perhaps slightly more so for the aged than for the young. There was also no difference between young and old in the cAMP levels induced after 4-15 min. incubation of $\mathrm{T}$ cells with dimaprit: in 2 of 5 experiments with cells from young and in 3 of 5 experiments with cells from aged subjects there was a significant increase in the cAMP concentration (data not shown).

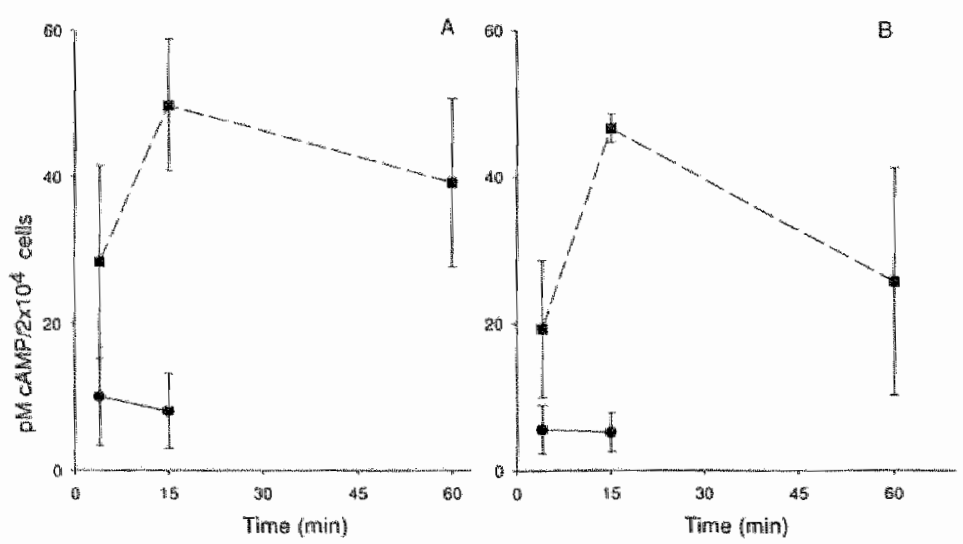

Itigure 1: cAMP hicrease in T" celts from young and aged indwidwals in response to forskolin. A rise in intracellular CAMP of similar magnitude and lknetics was observed in peripheral biood $T$ cells from young (A) and aged (B) subjects on incubation with $50 \mathrm{mM}$ forskolin. 


\section{Age-related decrease in the induction of TGF- $\beta$ mRNA synthesis by pokeweed mitogen}

To determine whether PWM induced TGF- $\beta$ synthesis, we examined the levels of TGF- 3 mRNA. in $T$ cells from five young individuals after incubation with PWM. As shown in Fig. 2, on the average, there was a 10-fold increase in the TGF- $B$ mRNA levels in the PWM-exposed as compared to the control samples from young individuals $(p<0.01$ for undiluted and $p<0.05$ for $1: 10$ diluted samples). In contrast, no difference was found in the values for TGF $\beta$ mRNA detected in the samples from 6 aged individuals.

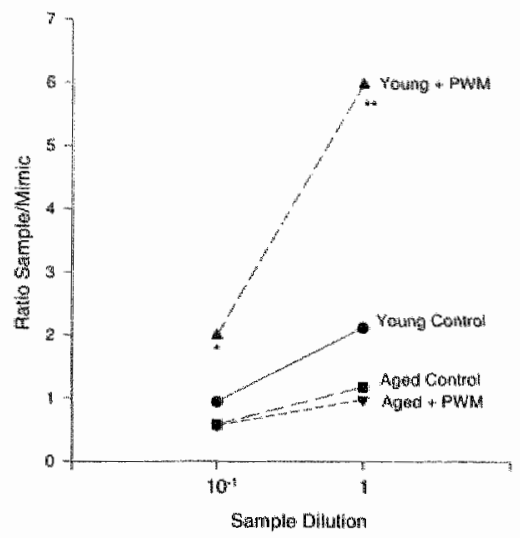

Figure 2: TGF $\beta$ mRNA induction by $P W M$ in PBL T cells from young $(n=5)$, but nor from aged $(n=6)$ individuals. The band areas of the RT-PCR products of samples/mimic $\left(10^{-3}\right.$ attoM) were plotted against the amount of sample used for the amplification. The plotted values represent the mean ratios for the groups obtained at the indicated sample dilutions. * $p<0.05 ; * * 0<0.01$.

\section{T cell subset frequencies in PBL and spleen}

A possible explanation of the altered functional activity in $T$ cells from elderly donors might be that the proportion of particular T-cell subsets, having in itself different functional capacities, changes with age. PBL and spleen cells were, therefore, examined by flow cytometry and the percentages of the different $C D 8^{*} T$ cell subsets are shown in Fig. 3. It was observed that the changes with age within certain populations were mostly similar in PBL and spleen, although too few samples of spleen cells were examined to allow firm conclusions. The percentage of $\mathrm{CD} 3^{+} \mathrm{CD}^{+} \mathrm{T}$ cells remained stable with age, while the total percentage of CD3 $3^{+} \mathrm{CD} 8^{*} \mathrm{~T}$ cells exhibited an age-related decrease in PBL, as also seen by others ${ }^{21,22,23}$. Splenic T cells exhibited a similar pattern (Fig. 3A). Among CD8 ${ }^{+}$T cell subsets, an increase in CD57 $7^{+} \mathrm{CD}^{+}$cells was seen in both PBL and spleen, although the difference did not reach significance (Fig. 3B). $\mathrm{CD} 11 \mathrm{~b}^{+} \mathrm{CD} 8^{+}$cells remained relatively stable. The dual and triple stain analyses for $\mathrm{CD} 11 \mathrm{~b}$, CD57 and CD28 expression within the $\mathrm{CD}^{*}$ cells revealed decreases in the CDIIb CD57 $\mathrm{CD} 8^{*}$ and in the CD28. CD8* $\mathrm{T}$ cells, but due to variability in the results and small sample sizes, these differences were not statistically significant (not shown). The CD4 CD45RO+ subset, representing the memory CD4 $\mathrm{T}$ cells, showed increases in both the PBL and spleen cells from 
the aged (not shown). Although the $\mathrm{CD}^{+} \mathrm{CD} 45 \mathrm{RO}^{*} \mathrm{~T}$ cell subpopulation also increased in the PBL, it appeared to decrease in the spleen (Fig. $3 B$ ).

Ai

EYMPHOEYTE SUESETS WW PBL ANO SPLEEN FROM YOUNG AND AOED SUBNECTS

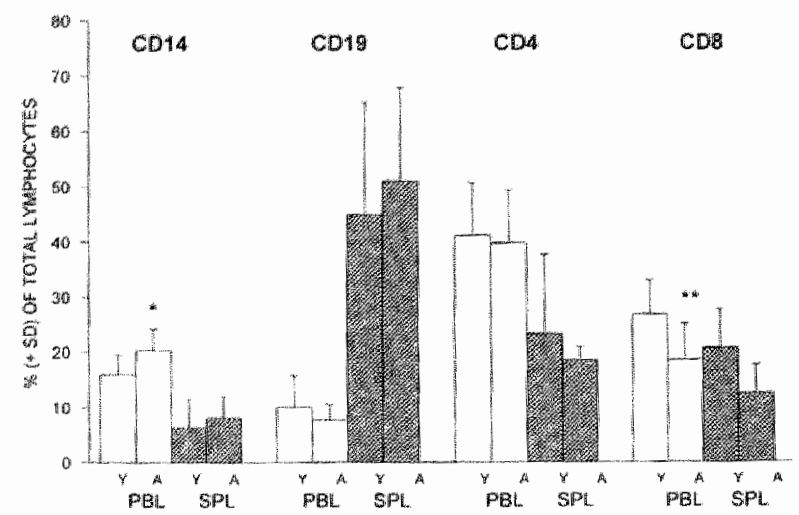

CDA. T CELL SUBSETS IN PBL AND SPLEEN FROM YOUNG AND AGED SUBJECTS

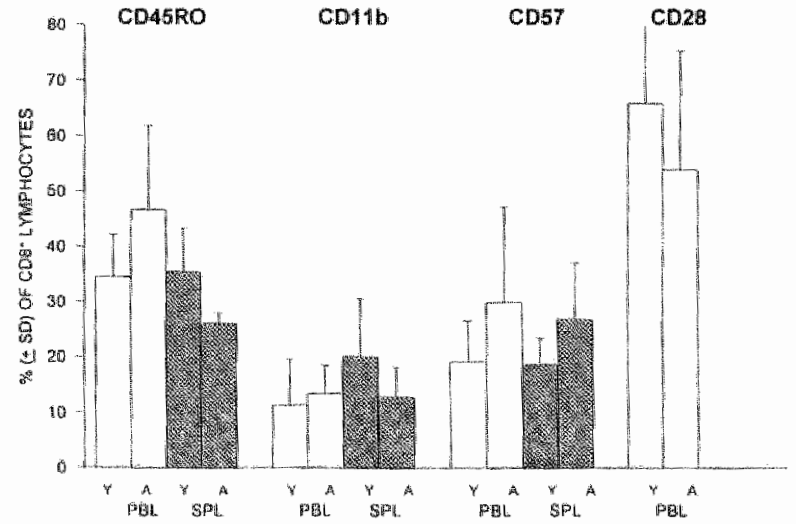

Figure 3 : Lymphocyld and $T$ edl subsets im peripheral blood (PBL) and spleen (SPL) from young (Y) and aged (A) individnats. A: Lymphocyte subsets; B: CD8* T cell subsets. Cells were double and/or triple stained for surface markers as indicated in materials and methods. Availability of sufficient cells frequently limited the number of subsets that conld be analysed simullaneously $(n=7-20$ for PBL and $3-4$ for spleen). $p<0.05$; * p $<0.005$.

\section{Discussion}

To our knowledge, we are the frist to describe functional studies on human splenic as compared to PBL $T$ cells. We find that, as in peripheral blood, splenic CD8 ${ }^{\text {t }} \mathrm{T}$ cells from young individuals exhibit an inhibitory effect on the $(S A C+1 L-2)$ induced splenic $B$ cell differentiation. Early functional studies by Damle et al ${ }^{24}$ suggested that the $\mathrm{CDN}^{2} \mathrm{~b}^{+} \mathrm{CD}^{+}$cells contained 
immunoregulatory, but not cytotoxic $\mathrm{T}$ cells. $\mathrm{CDI} 1 \mathrm{~b}^{+} \mathrm{T}$ cell clones derived from both $\mathrm{CD} 4^{+}$and $\mathrm{CD}^{+} \mathrm{T}$ cells were shown to exhibit suppressor activity ${ }^{25,26}$. The suppressor-effector activity of $\mathrm{CD} 8^{+} \mathrm{T}$ cells on $\mathrm{B}$ cells was reported to reside in the $\mathrm{CD} 8^{+} \mathrm{CD} 1 \mathrm{~b}^{+}$subse $^{27}$. On the other hand, $\mathrm{CD} 8^{+} \mathrm{CD} 28^{+} \mathrm{T}$ cells were shown to comprise cytotoxic cells and their precursors ${ }^{24}$. However, McFarland et al. ${ }^{28}$ showed that the $\mathrm{CD} 11 \mathrm{~b}$ antigen is a marker for murine $\mathrm{CD} 8^{+}$cytotoxic $\mathrm{T}$ cell activation. Moreover human $\mathrm{CD} 28^{\prime \prime} \mathrm{CD} 8^{+} \mathrm{T}$ cells $\left(\mathrm{CD} 11 \mathrm{~b}^{+}\right)$mediate potent anti-CD3 redirected cytotoxicity against FCR-bearing targets ${ }^{29}$. It seems, therefore, that $\mathrm{CD}_{1} 1 \mathrm{~b}^{+}\left(\mathrm{CD} 28^{-}\right)$and $\mathrm{CD} 1 \mathrm{bb}$ $\left(\mathrm{CD} 28^{+}\right) \mathrm{T}$ cells play different roles in the immune response depending on the system studied. This is also apparent from the present findings, in which the $\mathrm{CD} 1 \mathrm{Lb}^{+} \mathrm{CD} 8^{+} \mathrm{T}$ cells seemed necessary for the suppressor activity on ISC production when spleen cells were studied, whereas they appeared dispensable for this activity when PBL cells were examined. With respect to the relative roles of virgin and memory $\mathrm{T}$ cell subsets in suppressor activity, Hoshino et a $\mathrm{L}^{30}{ }^{30}$ reported that 75 to $80 \%$ of peripheral blood $\mathrm{CD} 11 b^{+} \mathrm{T}$ cells express CD45RO. It could be that $\mathrm{CD} 11 \mathrm{~b}^{+} \mathrm{CD} 8^{+} \mathrm{T}$ cells in the spleen are mostly $\mathrm{CD} 45 \mathrm{RO}^{+}$and that by removing this population one would affect the functional activity of remaining $\mathrm{CD}^{+} \mathrm{T}$ cells. It has been suggested, however, that in PBL the $\mathrm{CD}^{+}{ }^{+} \mathrm{CD} 45 \mathrm{RA}^{+} \mathrm{T}$ cells are responsible for the suppression of $\mathrm{Ig}$ production in the PWM-driven system ${ }^{31.32}$, while Bass et al. ${ }^{33}$ report that cytotoxic effector cells can be generated from $\mathrm{CD} 45 \mathrm{RA} \mathrm{CD}^{+}{ }^{+} \mathrm{T}$ cells.

Aged $T$ cells exhibit reduced proliferative responses to mitogens, mAbs to cel]. surface receptors, and even to phorbol ester and ionomycin ${ }^{34,35,36,37}$. The age related decrease in $\mathrm{T}$ cell proliferative responses is more pronounced in $\mathrm{CD} 8^{+}$than in $\mathrm{CD} 4^{+} \mathrm{T}$ cells ${ }^{9}$. B cell function is less affected by age. Numerically, as previously observed by others ${ }^{21,22,23,38}, \mathrm{CD}^{*}{ }^{*} \mathrm{~T}$ cells in humans tend to remain constant with age, while the $\mathrm{CD} 8^{+} \mathrm{T}$ cells decrease. Within the $\mathrm{CD} 8^{+} \mathrm{T}$ cell subpopulations, there is an expansion of the cytotoxic $\mathrm{CD} 8^{+} \mathrm{CD} 28^{-1}\left(\mathrm{CD} 11 \mathrm{~b}^{+}\right) \mathrm{T}$ cell subset which correlates with an increase in the anti-CD3 redirected cytotoxic activity, while the suppressor $\mathrm{CD} 8^{+} \mathrm{CD} 28^{+} \mathrm{T}$ cell subset decreases with age ${ }^{30.39,40}$. In the relatively small sample sizes studied here, there was a similar trend in both PBL and spleen cells. No previous reports on age-related changes in human splenic $T$ cell subpopulations are available. The age-related increase in memory $\left(\mathrm{CD} 45 \mathrm{RO}^{+}\right)$and relative decrease in virgin (CD45RA $\left.{ }^{*}\right) \mathrm{T}$ cells, described for PBL by others ${ }^{41,42,43}$, was seen in the present study in $\mathrm{CD} 8^{+}$as well as $\mathrm{CD} 4^{+} \mathrm{T}$ cells from PBL, but was not seen for $\mathrm{CD} 8^{+}$cells in spleen. Observations on larger numbers of individuals, where spleen and PBL from the same subject are compared, are clearly needed.

In agreement with the notion that $\mathrm{B}$ cell function is relatively retained with age, the ISC response obtained in cultures of ( $\mathrm{SAC}+\mathbb{L}-2)$ stimulated $\mathrm{B}$ cells was very similar with cells from aged and young individuals. Using such T-cell-independently activated B cells as a target, we show that peripheral blood $\mathrm{CD}^{+} \mathrm{T}$ cells from aged donors lack the suppressor-effector activity on the ISC response of autologous $\mathrm{B}$ cells that is almost invariably observed in appropriately stimulated $\mathrm{CD}^{+} \mathrm{T}$ cells from young individuals. This lack of suppression on the ISC response is seen in all the experiments with PBL $T$ cells from aged indiwiduals, whether the $C D 8^{*} \mathrm{~T}$ cells are activated by PWM, dimaprit or CAMP upregulating agents.

CAMP levels may be increased in $T$ cells by mitogens such as PWM ${ }^{4}$ and $C o n A^{44}$. H2-R agonists also induce increases in intracellular cAMP in $\mathrm{T}$ cells, particularly in the $\mathrm{CD} 28^{-} \mathrm{CD} 8^{+} \mathrm{T}$ cell 
subset. The immunoregulatory activity of young $\mathrm{CD} 8^{+} \mathrm{T}$ cells on the ISC response seen in the present study is likely to be, at least in part, mediated by an increase in the intracellular CAMP. Both in our previous work ${ }^{2}$ and here, we show that the immunoregulatory activities in $\mathrm{CD} 8^{+} \mathrm{T}$ cells induced by PWM, the H2-R agonist, dimaprit, and CAMP upregulating agents are abolished by the protein kinase $\mathrm{A}$ inhibitor. HA1004. A rise in intracellular cAMP is known to depress $\mathrm{T}$ cell proliferation through inhibition of $\mathrm{LL}-2 \mathrm{R}$ expression ${ }^{45,46}$ and cytokine production ${ }^{47,48,49}$, including helper factors for $\mathrm{B}$ cell differentiation. These effects on $\mathrm{T}$ cells, however, do not explain how an inhibitory effect on T-independently activated B cells in the presence of excess IL-2 would be mediated by such $T$ cells.

Early studies by Tam and Walford ${ }^{50}$ on cyclic nucleotide levels in resting and stimulated splenic lymphocytes from young and old mice reported a decrease in the resting levels of CAMP in T cells from spleens of old as compared to young mice. Their studies on human cells also reported that the levels of CAMP in resting peripheral blood $T$ lymphocytes from aged individuals were markedly decreased when compared to young individuals ${ }^{50}$. However others reported no age associated difference in the concentration of CAMP in resting peripheral blood lymphocytes ${ }^{51}$, and the cAMP-dependent protein kinase activity in peripheral blood lymphocytes from the elderly was reported to be unchanged ${ }^{52}$. The present results do not suggest that the lack of suppressor activity found in the $T$ cells from aged individuals is due to a defect in the intracellular CAMP response to the agents used. When we specifically measured the cAMP concentration in peripheral blood $T$ cells with and without exposure to forskolin, we found no difference between young and aged individuals. We conclude, therefore, that it is unlikely that the defective mechanism underlining the lack of immunoregulatory function in $\mathrm{CD} 8^{+} \mathrm{T}$ cells from aged individuals is related to a defect in the activation of the CAMP second messenger system.

Another possible mechanism that may contribute to a lack of immunoregulation in $\mathrm{CD}^{+} \mathrm{T}$ cells from aged individuals is an age-related defect in cognate $T-B$ cell interaction. The $T$ cell antigen CD28 is an important co-stimulatory molecule (reviewed $\mathrm{in}^{53}$ ) and is involved in T cell-induced B cell differentiation ${ }^{54}$. Effros ${ }^{40}$ reported a decline in the percentage of cells expressing the CD28 molecule in peripheral blood $\mathrm{T}$ cells of aged individuals. In addition, it has been shown that T cells from aged mice are defective in their response to costimulation mediated by $\mathrm{CD} 28^{55}$, but that this decreased response is not solely explained by a reduced expression of $\mathrm{CD} 28$ on $\mathrm{T}$ cells. The decreased proliferative response seen in $\mathrm{CD}^{+} \mathrm{CD} 11^{\prime \prime} \mathrm{T}$ cells from aged donors, when activated by PHA or anti-CD3 in the presence of CD28 mAb and $\mathbb{L}-2$, shown by Grossmann?, also suggests that the CD28 costimulatory pathway in aged human cultures might be defective. Furthermore, poorly developed T-B cell interactions may also be the consequence of a defective upregulation of the CD40L on $\mathrm{T}$ cells, as the CD40L and CD28 costimulatory pathways are interdependent ${ }^{56}$. We also examined the effectiveness of anti-CD3 activated $\mathrm{T}$ cells in inducing $\mathrm{B}$ cell proliferation. The anti-CD3 used for this study, when applied in sufficient quantity, is active even in the absence of accessory cells and thus relatively independent of costimulation via $\mathrm{CD} 28^{57}$. Low $\mathrm{B}$ cell responses were observed in a high percentage of cultures in which aged $\mathrm{T}$ cell donors were studied, regardless of the age of the B cell donor, again suggesting a reduced ability of the $T$ cells from aged donors to interact with $B$ cells. 
Absence of down regulation of $B$ cell differentiation could be due to an age-related change in $B$ cell sensitivity to the CD $8^{*} \mathrm{~T}$ cell influence or else to a defect in the PWM induced $\mathrm{T}$ cell response. As shown in our previous work ${ }^{2}$, the suppressive effect of $\mathrm{CD}^{+} \mathrm{T}$ cells on the differentiation of ISC in the present system appears dependent on cell contact rather than being mediated solely by factors secreted into the culture medium. Nevertheless, when we studied the possible involvement of cytokines, it appeared that TGF $\beta$ had a role in mediating the immunoregulating effect of $\mathrm{CD}^{+} \mathrm{T}$ cells. We proposed that latent TGF $\beta$ could play an intermediate role, possibly in cell surface bound form, in this suppression. Indeed, it has recently been found that latent TGF- $\beta$ is able to bind to certain cell surface integrins. (D. Rifkiin, Dept of Cell Biology, this Medical School, personal communication) and could thus, prior to its activation, be present on the surface of the target activated B cells. Gray et al ${ }^{5}$ have reported that the interaction between CD8 ${ }^{*} \mathrm{~T}$ and $\mathrm{NK}$ cells leads to the production of TGF- $\beta$ in NK cells, and hence indirectly to the $\mathrm{CD}^{+} \mathrm{T}$ cell mediated suppression of $\mathrm{Ig}$ production in $\mathrm{B}$ cells. In each of these cases, an age-related defect could be the result of a less effective interaction between cells and therefore a lower production of active TGF- $\beta$.

In animal models of experimental autoimmune diseases, such as arthritis, endogenously produced as well as exogenously administered TGF- $\beta$ have a major dowm-modulating effect ${ }^{59}$. The present observation that PWM induces a marked increase in mRNA for TGF- $\beta$ in cells from young but not from aged individuals, requires further study to elucidate the functional significance of this finding. Defective TGF- $\beta$ production in aged subjects could be of great significance in explaining the tendency of the aged to exhibit certain autoimmune traits, including the tendency to exhibit enhanced levels of circulating autoimmune antibodies ${ }^{60}$.

\section{Acknowledgements}

The generous gift of dimaprit provided by Dr. Cantu TG from SmithKline Beecham Pharmaceuticals is much appreciated. We are greatly indebted to Drs. Finkelstein MS, Freedman ML and Perskin MH from the Division of Geriatrics, Dept. of Medicine. NYU Medical Center for their invaluable help in identifying healthy aged indiwiduals willing to participate in this study. The help of Dr. Demopoulos R (Resource for Tumot Tissue and Data, Kaplan Compreherisive Cancer center, NYU Medical Center) in obtaining spleen tissue from aged and young individuals is gratefully acknowledged. The expert assistance of Ms. Tomasello B throughout this study is greatly appreciated.

\section{References}

1 Pryjma J, Flad H-D, Ernst M and Pituch-Noworolska A - Pokeweed mitogen activated suppressor T-cells preferentially reduce immunoglobulin secretion by differentiated B-lymphocyles. Immunol Letters, 1986; 13:273. 279 .

2 Crisi GM, Katz IR, Zucker MB and Thorbecke GJ - Induction of inibitory activity for B cell differentiation in human CD8 $\mathrm{T}$ cells with pokeweed mitogen, dimaprit, and CAMP upregulating agents: countersuppressive effect of platelet factor 4 . Cell Immunol, 1996; 172:205-226. 
" Khan MM, Sansoni P. Engleman EG and Melmon KL - Pharmacologic effects of autacoids on subsets of T cells. Regulation of Expression/Function of Histarnine-2 receptors by a subset of suppressor cells. J Clin lnvest, 1985; $75: 1578-1583$.

4 Ohara I. Kishumoto $\mathrm{T}$ and Yamamura $\mathrm{Y}$ - In vitro immune response of humaan peripheral lymphocytes. III. Efiect wof anti-ju or anti-o anibody on PWM-induced increase of cylic mucleotides in hurman B Hymphocytes. $J$ lmmumol. $1978 ; 121.20888-2096$.

5 Hochwald GM Palladino MA and Thorbecke GJ - Transforming growth ractor-Bs" Endogenous immunosuppressive and anti-intlammatory molecules. CRC Press, Boca Raton, FL.1996.

- Whitson RH $\mathrm{J}_{r}$, Wong WL and Icakura $\mathrm{K}$ - Platelet factor 4 selectively inhibits binding of TOF beta 1 to the type $\mathrm{I}$ TGT-beta 1 receptor. I Cell Biochem, 1991; 47:31-42.

7 Gotteman SRS, Throbecke GI and Walford RL - Specific and nonspecific suppressor cells in aged animals. In aging and the immune response. Cellular and humoral aspects. Goid EA, ed. Marcel Dekker, Inc, New York and Basel, 1987: 243-270.

s Matour $D_{2}$ Melnicoff $M_{0}$ Kaye $D$ and Murasko $D M$. The role of $T$ cell phenotypes in decreased Jymphoproliferation of the elderly. Clin Immunol Immunopath, 1989; 50:82-99.

* Grosimann A, Ledbetter JA and Rabinowitch PS - Reduced proliferation in T lymphocytes in aged humans in predominantly in the $\mathrm{CDS}^{*}$ subset, and is unrelated to defects in transmembrane signaling which are predominantly in the CD4 subset. Exp Cell Res, 1989; 180:367-382.

10 Takaishi M. Kodomari N, Yamakido M, Onari K, Inamizu T, Yorioka N, Nakasaki M, Sadamoto K, Ikuta T, Ishioka $S$ and Nishimoto $Y$ - Supprssor cells in man as a function of age. Hiroshima. I Med Sci, 1980; 29:97-103.

11 Antonaci $S$, Jirillo $E$, Gallitelli $M$, Garofalo $A R$ and Bonomo $L$ - Impairment of $T$ inmunoregulatory activities in the induction of antibody specific response in aged humans. Mech Aging Develop, 1985; 30:251 259.

12 Ceuppens $\mathrm{JL}$ and Coodwin IS - Regulation of immenoglobulin production in pekeweed-mitogen stimulated cultures of tymphocytes from young and old adults. J Immunol 1982; 128:2429-2434.

1. Antonzi S, Jirillo E, Gallitelli M, Garofalo AR and Bonomo L - Regulatory effects mediated by OKT8* subsets on $B$ cell response in the elderly. Mech Aging Develop, 1987; 41:115-124.

14 Kung P. Goldstein G, Reinherz L and Schlossman SF - Monoclonal amibodies defining distinctive human T cell surface antigens. Science, $1979 ; 206: 347 \mathrm{~m} 349$.

is Böyum A. Isolation of mononuclear cells and granulocytes from human blood - Scand J Clin Lab Invest, 1968; $21: 77 \times 89$.

16 Pellegrino $M$, Ferrone $S_{n}$ and Theofilopoulos AN - Isolation of human $T$ and B lymphocytes by rosette formation with 2-aminoethylisothiquronium bromide (AET) treated sheep red blood cells and with monkey red blood cells. IJ Irmminol Moth $1976 ; 11: 2732279$

it Wysocki LI and Sato VI, - "Panning" for Iymphocytes: A method for cell selection. Proc Nall Acad Sci, 1978; $75: 2844-2848$.

18 Oronowicz E, Coutinho A and Melchers F - A plaque assay for all cells secreting Ig of a given type or class. Eur I Immuniol, $1976: 6.588-590$.

19 Harper Jf and Brooker $\mathrm{G}$ - Semomole sensitive radiommunoassay for cychic amp and cyclic GMP after 2'0 acetylation by acetic anhydride in aqueous solution. J Cyclic Nucleo Res 1975 ; 1:207-218.

20 Hirohata $S$, Jeliwek DF and Lipsky PE - T cell dependent activation of $B$ cell proliferation and differentiation by immobilized monoctonal antibodies to CD3. J Immund, 1988; 140:3736-3744.

7\$ Nagel JE, Chrest Fl, and Adler WH - Enumeration of $\Upsilon$ lymphocyle subsets by monotonal antibodies in young and aged humans. J Immunol, 1981: 1272086-2088.

22 Ligtharl GJ, Schuit HR and Hijmans W - Subpopulations of mononuclear cells in aging: expansion of the nulli cell compartment and decrease in the number of $\mathrm{T}$ and $\mathrm{B}$ cells in human blood. Immunol, 1985; 55:15-21.

2: Bender $\mathrm{BS}$, Chrest FJ, Naget IE and Adler WH - Peripheral blood CD8* subsets in young and elderly adults: Enumeration by two-color inmunohtuorescence and flow cytometry. Aging: Immunol Infect Dis, 1988; 1:23-29. 
34 Damle NK, Mohagheghpour N, Hansen JA and Engleman EG - Alloantigen-specific cytotoxic and suppressor T lymphocytes are derived from phenotypically distinct precursors. I Inmumol, 1983; 131:2296-2300.

25 Li SG, Ottenhoff TH, Elsen van den $\mathrm{P}$ " Koning F, Zhang L, Mak T and Vries de RR - Human suppressor T cell clones lack CD28. Eur J Immunol "1990; 20:1281-1288.

26 Koide 1 and Engleman $\mathbb{E G}$ - Differences in surface phenotype and mechanism of action between allosantigenspecific CD8 ${ }^{*}$ cytotoxic and suppressor T cell clones. I Immunol, 1990; 144:32-40.

27 Takeuchi T, DiMaggio M, Levine H, Schlossman SF and Morimoto C . CDll molecule defines two types of suppressor cells within the $\mathrm{Ts}^{+}$population. Cell Inmunol, 1988:111:398-409.

28 McFarland HI, Nahill SR, Maciaszek JW and Welsh RM-CD11b (Mac-1): a marker for CD8* cytotoxic T cell activation and memory in virus infection. Jmmunol, 1992; 149:1326 1393.

79 Azuma M. Phillips JH and Lanier LL - CD28 T lumphocytes. Antigenic and functional properties. IImmunol, $1993 ; 150: 1147-1159$.

39 Hoshino T, Yamada A, Honda I, Imai Y, Nakao M. Inoue M, Sagawa K, Yokoyama MM, Oizumi K and Itoh K . Tissue-specific distribution and age-dependent increase of human CD $1 \mathrm{~b}^{*}$ T cells. I lmmunol. 1993; 151:2237. 2246.

31 Takeuchi T, Rudd CE, Tanaka S, Rothstein DM, Schlossman SF and Morimoto C - Functional characterization of the CD45R (2H4) molecule on CD8 (T8) cells in the autologous mixed lymphocyte reaction system. Eur J Immunol, 1989; 19:747-755.

32 Hirohata $S$ - T8 cell regulation of human B cell responsiveness: regulatory influences of CD45RA* and CD45RA. T8 cell subsets. Cell Immunol, 1991; 133: 15-26.

33 Bass HZ, Yamashita N and Clement LT - Heterogeneous mechanisms of human cytotoxic T lymphocyte generation. I. Differential helper cell requirement for the generation of cytotoxic effector cells from $\mathrm{CD} 8^{+}$ precursor subpopulations. J Immunol, 1992; 149:2489-2495.

34 Gillis S, Kozak R, Durante M and Weksler ME - Immunological studies of aging. Decreased production of and response to T cell growth factor by lymphocytes from aged humans. J Clin Invest, 1981; 67:937-942.

35 Schwab $\mathrm{R}$, Hausman PB, Rinnooy-Kan $\mathrm{E}$ and Weksler ME - Immunological studies of aging. X. Impaired $\mathrm{T}$ lymphocytes and normal monocyte response from elderly humans to the mitogenic antibodies OKT3 and Leu 4. Immunol, $1985 ; 55: 677-684$.

36 Weksler M and Hutteroth TH - Impaired Iymphocyte function in aged humans. J Clin Invest, 1974: 53:99-104.

37 Gauchat JF, Walker C, De Weck AL and Stadler BM - Stimulation-dependent lymphokine mRNA levels in human mononuclear cells. Eur J Immunol, 1988; 18:1441 -1446.

Nagel JE, Chrest FJ, Pyle RS and Adler WH - Monoclonal antibody analysis of T-lymphocyle subsets in young and aged adults. Imnnunol Comm, 1983; 12:223-237.

37 Fagnoni FF, Yescovini R, Mazzola $M$, Bologna $G$, Nigro E, Lavageto $G$, Franceschi $C$, Passeri $M$ and Sansoni $P$ - Expansion of cytotoxic CD8* CD28" $\mathrm{T}$ cells in healthy aging people, including centenarians. Inumunoll, 1996; 88:501.507.

40 Effros RB, Boucher N, Porter V. Zhu X, Spaulding C. Walford RL, Kironenberg M, Cohen D and Schtuchter $P$. Decline in $C D 28^{*} T$ cells in centenarians and in long-term $T$ cell cultures: A possible catuse for both in wiwo and in witro immunosenescence. Exp Gerontol, 1994; 29:601-609.

41 DePaoli P, Battistin S and Santini GF. Age-related changes in human lymphocyte subsets: Progressive reduction of the CD4 CD45R (suppressor inducer) population. Clim Immunol Immunopath, $1988 ; 48: 290-296$.

42 Warren RP, Yonk LJ, Burger RA and Singh VK. Age-related changes in CD45R and CDw29* helper T cells in human subjects. Aging; Immunol Infect Dis, 1990; 2:91-94.

${ }^{3}$ Cossarizza A, Onolani C, Paganelli R, Barbieri D, Monti D, Sansoni P, Fagiolo U, Castellani G, Bersani F, Londei $\mathrm{M}$ and Franceschi $\mathrm{C}$. CD45 isoforms expression on $\mathrm{CD}^{+}$and $\mathrm{CD} 8^{+} \mathrm{T}$ cells throughout life from newborns to centenarians: implications for T cell memory. Mech Aging Dev, 1996: 86:173 195 
4 Takigawa M and Wakman BH. Mechanismus of lymphocyte "deletion" by high concentrations of ligand. 1. Cychic AMP tevels and cell death in T-Jymphocytes exposed to bigh concentrations of concanavalin A. Cell Immunol, $1981 ; 58: 29-38$.

4s Rincon M, Tugores A, Lopez-Rivas A, Silva A, Alonso M, De Landazuri MO and Lopet-Botet M. Prostaglandin E2 and the increase of intracel lular cAMP inhibit the expression of interleukin 2 receptors in human $T$ cells. Eur I Immunol, 1988; 18:1791-1796.

46 Krase DS and Deutsch C. Cyclic AMP directly mhibits L-2 receptor expression in humat I cells: expression of both p5s and p75 subunits is affected. I Immunol, 1991; 146:2285-2296.

al Gilber KM and Hoffmants MK. CAmp is an essential signal in the induction of antibody production by $B$ cells but inhibits helper function of T cells. J Immunol, 1985; 135:2084-2089.

48 Averill LE Stein RL and Kammer OM. Control of human T-lymphocyte interleukin-2 production by a cAMP. dependent pathway. Cell Immunol, 1988; 115:88-99.

49 Kammer GM. The adenylate cyclase-CAMP protein kinase A pathway and regulation of the inmune response. Irnmunol Tod, 1988; 9:222:229.

50 Tam CF and Walford RL. Alterations in cyclic nucleotides and cyclase-specific activities in T lymphocytes of aging normal humans and patients with Down's syndrome. I Immunol, 1980; 125:1665-1670.

\$) Mark DH and Wekster ME. Immunologic studies of aging. Vul: No change in cyclic nuclectide concentration in T-Iymphocytes from old humans despite their depressed proliferative response. IImmunol, 1982; 129:2323-2325.

52 Krall JF, Fermandez EI and Connelly-Fittingoff M. Lymphocyte protein kinase activity in cells from young and ejderly men and women. Proc Soe Exp Biol Med, 1985; 180:462-467.

53 June CH, Bluestone JA, Nadler LM and Thompson CB. The B7 and CD28 receptor families. Inmunol Tod, 1994: 15:321-331.

5.4 Damle NK, Linsley PS and Ledbetter JA. Direct helper T cellinduced B cell differentiation involves interaction between $T$ cell antigen $C D 28$ and $B$ cell activation antigen B7. Eur Immunol, 1991; 21:1277-1282.

5s Engwerda CR, Handwerger BS and Fox BS. Aged T cells are hyporesponsive to costimulation mediated by CD28. J Intmunol, 1994; 152:3740-3747.

s6 Klaus S1, Pinchuk LM, Ochs HD, Law CL. Fanslow WC, Armitage RJ and Clark EA. Costimulation through CD28 enhances $T$ cell-dependent $B$ cell activation via CD40-CD40L interaction. J Immunol, 1994; 152:56435652.

57 Geppert TD and Lipsky PE. Accessory cell independent proliferation of human T4 cells stimulated by immobilized monoclonal antibodies to CD3. J Immunol, 1987; 138:1660-1666.

5s Gitay JD. Hirokitwa M and Horwiz DA. The role of transforming growth factor beta in the generation of suppression: an interaction between CD8* $\mathrm{T}$ and NK cells. I Exp Med, 1994; 180:1937-1942.

59 Thorbeck G., Shah R, Leu CH, Kuruvilla AP. Hardison AM and Paltadino MA. Involvement of endogenous tumor necrosis factor alpha and transforming growth factor beta during induction of collagen type II arthritis in mice. Proc Natl Acad Sci USA, 1992: 89:7375-7379.

6 Weksler ME, Schwab R, Huerz F, Kint YT and Continho A. Cellular basis for the age-associated increase in abitoimmune restctions. Int Immunol, 1990; 2:329-235. 


\section{Chapter \\ 3}

\section{Evaluation of presence and functional activity of potentially self-reactive $T$ cells in aged mice}

GM Crisi, Tsiagbe VK, Russo C, Basch RS and Thorbecke GJ

Dept. of Pathology and Kaplan Comprehensive Cancer Center, New York University School of Medicine, New York, NY 10016 


\section{Summary}

Autoimmunity is known to increase in ageing. A possible factor could be an alteration in the $T$ cell repertoire with advancing age. Antibodies to the variable region of the $\beta$ chain of the TCR activate $T$ cells and can serve as probes for analysis of the $T$ cell repertoire. We have used VB3 and V $1.7 \mathrm{a}$ antibodies to determine the presence and functionality of normally deleted $T$ cells bearing potentially self-reactive TCRs in peripheral lymphoid tissue and blood from aged (SJL/ $\times B A L B / c) F I, L A F 1$ and BALB/c mice.

Although an occasional $20-24$ mos old mouse exhibited $V \beta 3^{+}$or $V \beta 17 a^{+} T$ cells in their $L N s$ or PBLs slightly above the range for normal young mice of these $\mathrm{I}-\mathrm{E}^{+}$strains, there was no striking "escape" from the normal thymic deletion process. However, responsiveness to anti-VB3 and anti-V $\beta 17 \mathrm{a}$ was slightly higher in aged, and particularly in aged thymectomized, than in young mice. This was in contrast to proliferative responses to stimulation with antibody to the normally expressed VP8, which were lower in the lymph nodes from aged than from young mice.

The PBL of some 30-36 mos old mice were also examined. Enhanced numbers of "forbidden" V $\beta$ bearing $T$ cells were seen more frequently at this age. In spite of the age-related decrease in overall $C D 4 / C D 8 \mathrm{~T}$ cell ratios in all organs, the mice with relatively high $V \beta 17 \mathrm{a}^{+} \mathrm{T}$ cells exhibited proportionally more $\mathrm{CD} 4^{+}$cells in that $\mathrm{V} \beta$ population.

We conclude that the "forbidden" $T$ cells that respond to anti-V $\beta$ stimulation in the 20-24 mos old mice are most likely of extra-thymic origin, since they were more readily detectable in aged TX mice. Potentially self-reactive $\mathrm{CD} 4$ (and CD8) single positive T cells were detectable in PBL only in very aged ( $30-36$ mos old) euthymic mice.

\section{Introduction}

Age-related alterations in the immune function include changes in lymphocyte subset composition, reduction in primary and secondary humoral and cellular immune responses and an increase in the incidence of autoimmune diseases'. Thymic dysfunction has been postulated to be a primary event in the immunosenescence seen with advancing age ${ }^{2}$. However, Gonzales-Quintial and Theofilopoulos ${ }^{3}$ report that the thymic $V \beta$ repertoire remains stable throughout life despite severe reduction in cellularity and thymic output in the aged thymus. Indeed, T cells seen in the periphery of aged animals are not necesssarily long-lived quiescent thymus derived cells, but often represent $T$ cells that continue to proliferate in the periphery ${ }^{4}$, and can also represent population(s) of $\mathrm{T}$ cells that originate in peripheral organs.

Although the thymus is the principal organ for $T$ cell differentiation, it is certainly not the only site. Many reports document the existence of Thy $-1^{+}$cells in congenitally athymic mice and their number increases with age ${ }^{5,6}$. Both the intestinal epithelium and the liver have been proposed as sites of extrathymic T-cell production and selection ${ }^{7,8,9,10,11}$. In fact, peripheral engraftment of murine small intestine into athymic irradiated and bone marrow reconstituted mice can direct $T$ cell development of the bone marrow stem cells ${ }^{12}$. Poussier et al. ${ }^{8}$ have demonstrated that thymectomized fetall liver radiation chimeras generate intestinal epithelial lymphocytes (IELs) in normal numbers in the absence of the thymus. These studies demonstrate that the liver and 
intestinal epithelium are thymus-independent sites of $\mathrm{T}$ cell lymphopotesis. However, the lower numbers of $\gamma \delta$ and $\alpha \beta$ IELs in athymic as compared to euthymic mice and the effect of fetal thymus grafts suggest an influence of the thymic stroma on the peripheral development of TCR* IELs $^{13}$. Neonatally thymectomized adult mice contain in their peripheral tissue autoreactive $T$ cells $^{14}$. Whether these cells are thymocytes that escaped clonal deletion in the neonatal thymus or represent autoreactive $T$ cells of extrathymic origin is not yet clear. It has been shown that extrathymic $\alpha \beta \mathrm{T}$ cells have high frequencies of potentially self-reactive $\mathrm{T}$ cells ${ }^{7.8 .45}$. Nevertheless, both IELs expressing potentially autoreactive MHC-class II dependent/specific TCR and MHC-class I restricted TCR can undergo in situ negative selectio ${ }^{8.16}$.

There is a gradual expansion with age of the extrathymic pathway of T cell differentiation in the liver ${ }^{11,17}$. In fact, the hepatic pathway of $T$ cell differentiation is in its most activated state in aged mice with involuted thymi and in congenitally athymic mice ${ }^{15,18}$. A major population of extrathymic $T$ cells seen in the periphery of aged mice seem to comprise cells of hepatic origin ${ }^{17}$. Although IEL are known to show an age-dependent increase in their cell number ${ }^{19}$ (19), they do not often appear in the circulation or in peripheral organs 8,20 .

Reconstitution of the peripheral $T$ cells in $q$-irradiated rats by bone marrow from syngeneic donors is impeded by cyclosporin $A(\mathrm{CsA})$ treatment ${ }^{21,22}$. After termination of CsA treatment, autoreactive $\mathrm{T}$ cells appear in the periphery ${ }^{23}$, presumably as the result of impaired repertoire selection in the thymus ${ }^{23,24}$. This phenomenon has been attributed to defective expression of MHC-class II on the medullary dendritic cells ${ }^{23,25}$. In view of the lower expression of MHC-class II on thymic epithelial cells ${ }^{26}$ and on epidermal dendritic cells in aged mice ${ }^{27}$, a defect in the thymic selection mechanism in aged mice might occur. The findings to date, however, suggest that the thymus retains it"s function in positive and negative selection throughout life and that thymic involution is not overtly associated with leakage to the periphery of potentially selfreactive $\mathrm{T}$ cells ${ }^{3}$.

The present studies were undertaken to evaluate not only the presence of "forbidden" $T$ cell clones in aged mice by detection via their V $\beta$ expression, but also their possible functional actiwity after stimulation with anti-VB and IL-2. The results show that responsiveness to stimulation of $T$ cells that should have been deleted is more frequently detected in thymectomized than in euthymic aged mice.

\section{Materials and Methods}

\section{Mice}

SILJ and LAFI mice were purchased from the Jackson Laboratory (Bar Harbor, ME), BALB/C mice from Charles River Labs (Wilmington, MA). BALB.B mice and all F1 hybrid mice used were bred and allowed to age in the animal facilities of New York U. School of Med. Mice were allowed to age in the animal facilities of New York U. School of Med. Animals with tumors were excluded from the studies. Thymectomy was performed on SILJJ and SJL/J X BALB/C (SxB) F1. mice (4-6 months old) under nembutal $(60 \mathrm{mg} / \mathrm{g})$ anesthesia. The thymus was removed by suction $^{28}$. Thymectomized (TX) and sham-TX mice (NL) were killed 16-20 months later. 


\section{Analysis of cell surface markers by now cytometry}

Peripheral blood was collected in an eppendorf tube containing heparin. Mononuclear cells were separated by Lympho-Paque density gradient centrifugation (Nyegaard \& Co, Oslo, Norway). Cell suspensions were prepared from pooled axillary and brachial lymph nodes, spleen and thymus of indiwidual mice. Cells were stained with a combination of three different murine monoclonal antibodies. The staining buffer used consisted of phosphate buffered saline with $1 \%$ bovine serum albumin, $0.1 \%$ sodium azide and $10 \mathrm{mg} / \mathrm{mil}$ human gamma globulin (to block Fc receptors). The fluorescein-labeled (FITC) antibodies were anti-Thyl.2 (Caltag Labs, So. San Francisco, CA), anti-Lyt2 (Becton Dickinson, Mountain View, CA), and anti-VB17a [KJ-23 $\left.{ }^{29}\right]$. The phycoerythrin-labeled (PE) antibodies were anti-Lyt2 (Becton Dickinson, Mountain View, CA) and anti-L3T4 (Caltag Labs). The biotim-labeled antibodies were anti-VB3 [KJ-25 ${ }^{30}$ ], anti-VB17a anti-VB8.1 [MRS-2 ${ }^{31}$ ] (PharMingen, San Diego, CA) and anti-VP11 [RR3-15 ${ }^{32}$, as well as isotype control mouse IgG2a (Caltag Labs). Streptavidin-R613 was purchased from GIBCO BRL (Grand Island, NY), and the streptavidin-FITC from Caltag Labs. Analysis was done with a FACScan flow cytometer (Becton Dickinson).

\section{Stimulation of T cells}

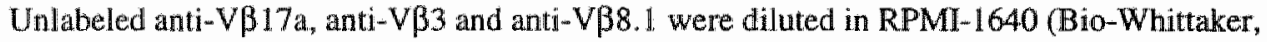
Walkersville, MD), at the following concentrations: anti-V $\beta 3,40 \mathrm{mg} / \mathrm{ml}$, anti-V $\beta 8.1,1 \mathrm{mg} / \mathrm{ml}$, and anti-V $\mathrm{V} 17 \mathrm{a}, 2 \mathrm{mg} / \mathrm{ml}$. These concentrations gave optimal responses in cells from SJLJ mice which express the $V \beta 3$ and $V \beta 17$ a genes and in cells from (SxB) F1 mice which express the V $\beta 8$ gene. Flat-bottom 96 well microtiter plates (Linbro, McLean, VA) were coated with $50 \mathrm{ml}$ of the antibodies per well and left to incubate at room temperature for $1-2 \mathrm{hr}$. At the end of the incubation, the wells were washed twice with RPMT-1640 to remove the nonadherent mAb. Control wells were not coated with antibodies.

Single cell suspensions were prepared from the spleen and from pooled axillary and brachial lymph nodes (LNs) of individual mice in RPMI-1640 supplemented with penicillin and streptomycin, $2 \mathrm{mM} \mathrm{L}$-glutamine, $10 \mathrm{mM}$ Hepes (Bio-Whittaker), $5 \times 10^{-5} \mathrm{M} 2$-mercaptoethanol (BIO-RAD Labs, Richmond, CA), and 10\% fetal bovine serum (Atlanta, Norcross, GA). Cells were cultured at a concentration of $10^{5}$ per well in triplicate wells for $72 \mathrm{hr}$ in a $37^{\circ} \mathrm{C} \mathrm{CO}_{2}$ incubator. The cultures were pulsed with $0.2-1 \mathrm{mCi}\left[{ }^{3} \mathrm{H}\right]$-thymidine for the final $18 \mathrm{hr}$, harvested on glass fiber fillters and radioactivity was determined in a liquid scintillation counter. In most cases responses were measured in the presence of $10 \mathrm{U}$ recombinant human IL-2 per ml (generously donated by Hoffmann LaRoche, Nutley. NJ). Howewer, in experiments where responses were measured with and without added $I L-2$, no significant differences were observed. Stimulation indices were calculated by dividing the $\mathrm{cpm}$ obtained in anti-V $\beta$ stimulated cultures by the cpm obtained in control cultures. The cpm in control cultures varied between 400 and 2000. 


\section{Statisticall analysis}

The significance of differences was determined by $\mathrm{Chi}^{2}$ and Student's t-test. In analyzing the resulis for $V \beta 3$ and V $\beta 17$ a staining in peripheral blood, the background levels and the variation observed with VB17a staining from young mice was slightly greater than that seen with VB3 and VB11 staining. We designated the level above which VB3, VB11 or VB17a bearing $T$ cells were detectable above background as $>1 \%$ for $V \beta 3\left[\right.$ mean $+2 \mathrm{SD}$ for $(\mathrm{SxB}) \mathrm{F} 1_{\text {, mean }}+3 \mathrm{SD}$ for $\mathrm{LAF} 1],>1 \%$ for VB11 (mean $+2 \mathrm{SD}$ for BALB/c), and $>2 \%$ for VB17a [mean $+2 \mathrm{SD}$ for (SxB) F1 and LAF1].

\section{Results}

\section{Proliferative responses induced by anti-V $\beta$ antibodies}

The functional activity of VB3 and V $\mathrm{V} 17$ a expressing $T$ cells in LNs from young and aged (NL and TX) LAF1 and (SxB) F1 mice was examined by determining the proliferative responses to anti-V $\beta 3$ and anti-VB17a. Approximately 20-40\% of the mice in each experimental group had received two ip injections of $10^{7} \mathrm{PFU}$ of vaccinia virus ${ }^{33}, 2-4$ weeks before analysis. Results obtained with vaccinated and unvaccinated mice were taken together, as there were no significant differences between these groups.

There was a very low incidence of significant staining above the background of $\rrbracket$ of for V $\beta 3$ and $2 \%$ for VB17a in LNs from both aged and young LAF1 mice. Nevertheless, while none of the young LAF1 mice showed significant proliferative responses (stimulation index $\geq 1.4$ ) in their LNs and spleens, several of the aged mice did (Table 1 ). Taken together, responses were seen in $20-30 \%$ of LN and $30-40 \%$ of spleen cultures from aged (NL + TX) mice to each of anti-V 33 and anti-V $317 \mathrm{a}$. In spite of the large variation in these stimulation indices, the mean stimulation index observed with LNs from aged TX was significantly higher than that observed with aged NL LAF1 mice. Responsiveness to these two anti-V $\beta$ antibodies, taken together, increased with age in both nomal and TX LAFI mice $(0 / 20 \mathrm{vs} 11 / 48, \mathrm{p}=0.03)$.

There was no clear correlation between the presence of $V B 3^{*}$ or $V B 17 \mathrm{a}^{+} \mathrm{CD}^{+}$or $\mathrm{CD}{ }^{+} \mathrm{T}$ cells and responsiveness to anti-VB3 or anti-VB17a in indiwidual mice. Although the highest V 33 staining (CD4/CD8 ratio of 6.2) was seen in the $L N$ of an anti-V $\beta 3$ "responder" mouse, the other anti-V $\beta 3$ responder did not have detectable staining over background. Responsiveness to anti-

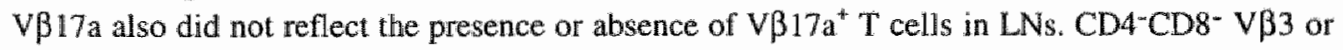
VP17a bearing $T$ cells were frequently detected in $L N s$ from aged TX mice buti, again, their presence seemed relatively unrelated to responsiveness.

Cells from none of the young (SxB) F1 mice exhibited staining above background for VB3 or $\mathrm{V} B 17$ a or responsiveness to anti-VP3, while $\mathrm{LN}$ cells from one of the seven mice examined responded to anti-VB17a (Table 2). Very little reactivity to anti-VB3 or anti-VB17a was detected in tissues from aged NL mice as well. However, the mean stimulation indices in IN or spleen cells from aged TX mice were higl as compared to those for young or aged NL. (SXB) F1 mice for both anti-VB3 and anti-VB17a. 
Table 1

Erfect of age on anti-V $\beta$ induced proliferative responses of LAF1 mouse T cells

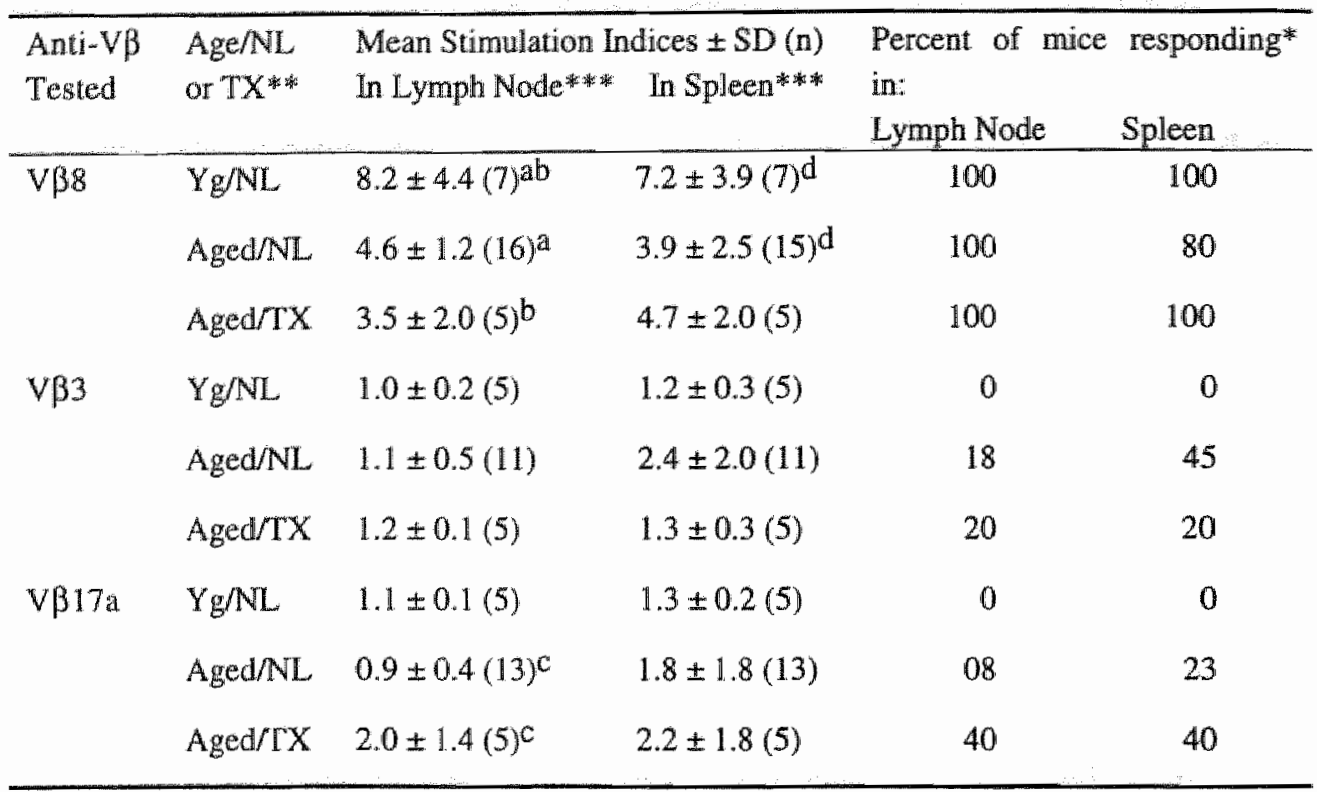

* Cultures were considered as responding when there was a statistically significant difference between the cpm in cells cultured with and without the anti-VP antibody and the ratio between these cpm was $>1.4$. The numbers of mice included for callulation of stimulation indices is the same as that used for calculation of response incidence.

NL $=$ nomal or sham-thymectomized" TX = thymectomized. Yg mice were 4-6 months, aged mice $20-24$ months oldi.

* Values with like footnotes were evaluated for statistically sugnificant differences: ${ }^{a} \mathrm{p}=0.005 ;{ }_{\mathrm{p}}=0.05 ;{ }_{\mathrm{p}}^{\mathrm{c}} \mathrm{p}<0.02$; $\mathrm{d}_{\mathrm{p}<0.03 \text {. }}$

Since not all the TX mice exhibited significant responses in their $\mathrm{LNs}$, the standard deviation for LN responses was high; the difference between aged $N L$ and aged TX mice therefore only reached statistical significance for the spleen responses to anti-V $\beta 3$. Tissues from aged TX (SxB) F1 mice exhibited responsiveness more frequently than did tissues from aged NL (SxB) F1 mice (3/32 ws $9 / 20, p<0.01)$, but this difference between TX and NL mice was not obvious in the LAFI mice.

As in $L A F 1$, staining for $V \beta 3$ and responsiveness in the $L N s$ of (SxB) F1 mice did not correlate. One aged mouse witl $1.8 \% \mathrm{VP3}^{+} \mathrm{T}$ cells (CD4/CD8 ratio of 16 ) showed responsiveness in spleen, but not in LN. Similarly, although $60 \%$ of the TX (SxB) F1 mice had significant responses to ant-V $\beta 17 \mathrm{a}$ in $\mathrm{LNs}$ (Table 3), none exhibited staining for V $\beta 17$ a above background.

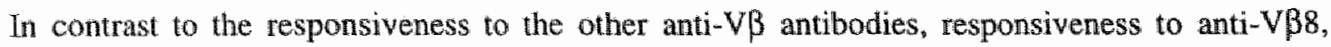
normally present in these strains, decreased with age (Tables 1 and 2 ). This was evident in spleen cultures from both strains examined and also in LN from LAFI mice. 
Table 2

Effect of age on anti-V $\beta$ induced proliferative responses of $S I L \times B A L B / C F I$ mouse

T cells

\begin{tabular}{|c|c|c|c|c|c|}
\hline \multirow{2}{*}{$\begin{array}{l}\text { Anti-VB } \\
\text { Tested }\end{array}$} & \multirow{2}{*}{$\begin{array}{l}\text { Age/NL } \\
\text { or TX* }\end{array}$} & \multicolumn{2}{|c|}{ Mean Stimulation Indices + SD (n) } & \multirow{2}{*}{$\begin{array}{l}\text { Percent of mice } \\
\text { in: } \\
\text { Lymph Node }\end{array}$} & \multirow{2}{*}{$\begin{array}{l}\text { responding } \\
\text { Spleen }\end{array}$} \\
\hline & & & & & \\
\hline \multirow[t]{3}{*}{$\mathrm{V} \beta 8$} & $\mathrm{Yg} / \mathrm{NL}$ & $8.8 \pm 7.2(7)$ & $6.6 \pm 2.8(7)^{a b}$ & 86 & 100 \\
\hline & Aged/NL & $7.3 \pm 11.4(7)$ & $2.7 \pm 2.8(8)^{\mathrm{a}}$ & 57 & 63 \\
\hline & Aged/TX & $5.7 \pm 2.3(5)$ & $3.1 \pm 0.7(5)^{b}$ & 80 & 100 \\
\hline \multirow[t]{3}{*}{ VB3 } & $\mathrm{Yg} / \mathrm{NL}$ & $1.0 \pm 0.1(7)$ & $0.9 \pm 0.3(7)^{\mathrm{C}}$ & 0 & 0 \\
\hline & Aged/NL & $1.1 \pm 0.2(8)$ & $0.9 \pm 0.2(8)^{\mathrm{d}}$ & 0 & 0 \\
\hline & Aged/TX & $1.5 \pm 0.9(5)$ & $1.4 \pm 0.3(5)^{\mathrm{cd}}$ & 40 & 40 \\
\hline \multirow[t]{3}{*}{$\mathrm{V} \beta 17 \mathrm{a}$} & $\mathrm{Yg} / \mathrm{NL}$ & $1.1 \pm 0.2(7)$ & $1.3 \pm 0.2(7)$ & 14 & 0 \\
\hline & Aged/NL & $1.3 \pm 0.3(8)$ & $1.2 \pm 0.3(8)$ & 13 & 25 \\
\hline & Aged/TX & $2.2 \pm 1.4(5)$ & $1.4 \pm 0.2(5)$ & 60 & 40 \\
\hline
\end{tabular}

* Cultures were considered as responding when there was a statistically significant difference between the cpm in cells cultured with and without the anti-VB antibody and the ratio between these cpm was $\geq 1.4$.

* $\quad \mathrm{NL}=$ normal or sham-thymectomized; $\mathrm{TX}=$ thymectomized. $Y \mathrm{~g}$ mice were 4-6 months, aged mico $20-24$ months old.

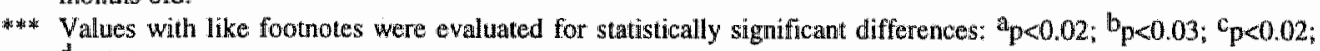
$\mathrm{d}_{\mathrm{p}<0.005 \text {. }}$

\section{Effect of age on $T$ cell subsets in different organs.}

The enumeration of $C D 4^{+}$and $C D 8^{*} \mathrm{~T}$ cells in PBL, spleen, and thymus of (SxB) FI (Fig. $1 \mathrm{~A}$ ) and LAFI (Fig. 1b) and in $L N$ (Table 3), reveals a marked decrease in CD4 $4^{-} \mathrm{T}$ cells in PBL and LN, but not in spleen or thymus. The VB $8^{*} \mathrm{~T}$ cell percentages in LNs decreased in parallel with the CD4 ${ }^{*} \mathrm{~T}$ cells (Table 3). However, the age-related decrease in responsiveness to anti-V $\beta 8$ appeared out of proportion to the decrease in V $\beta 8^{+} \mathrm{T}$ cell percentages (Tables 1-3). In aged $\mathrm{TX}$ LAF1 mice, the decrease in both $\mathrm{CD} 4^{*}$ and $V \beta 8^{*} \mathrm{~T}$ cells was more marked than in aged NL mice. However, in aged TX (SxB) F1 mice the decrease in total T cell percentages, as compared to aged NL mice, appeared due to a decrease in $C D 8^{+} \mathrm{T}$ cells rather than in $\mathrm{CD} 4^{*} \mathrm{~T}$ cells.

The percentages of $C D 8^{*} T$ cells remained constant with age in spleen, LN and PBL. There was no significant change in the normally very low percentages of $\mathrm{CD} 4^{+} \mathrm{CD} 8^{+}$(DP) $T$ cells in peripheral lymphoid tissues. As expected, the percentages of $\mathrm{CD}^{+} \mathrm{CD} 8^{*} \mathrm{~T}$ cells in the thymus decreased with age, more so in (SXB) F1 than in LAF1 mice. Nevertheless, in LAFI mice, the total number of thymocytes recovered per thymus was 3 fold less in aged than in young mice. 
Table 3

Effect of age on $T$ cell subsets in lymph nodes

\begin{tabular}{|c|c|c|c|c|c|c|c|}
\hline \multirow{2}{*}{$\begin{array}{l}\text { Mouse } \\
\text { strain }\end{array}$} & \multirow{2}{*}{$\begin{array}{l}\text { Age } / \mathrm{NL} \\
\text { or TX'a }\end{array}$} & \multicolumn{6}{|c|}{ Mean percentages of total cells \pm SD } \\
\hline & & $C D 4^{ \pm}$ & $\mathrm{CD}^{*}$ & $\mathrm{CD} 4^{ \pm} \mathrm{CD} 8^{ \pm}$ & $\underline{\mathrm{V} \beta 8^{ \pm}}$ & $\underline{V P 3}^{ \pm}$ & $\underline{\mathrm{V} B 17 \mathrm{a}^{ \pm}}$ \\
\hline \multirow[t]{3}{*}{ LAF1 } & $\mathrm{Yg} / \mathrm{NL}$ & $34.4 \pm 4.5^{b}$ & $29.8 \pm 4.0$ & $0.7 \pm 0.2$ & $7.2 \pm 1.0$ & $0.4 \pm 0.8$ & $0.5 \pm 0.5$ \\
\hline & Aged/NL & $21.4 \pm 6.1 b$ & $25.8 \pm 3.1$ & $1.7 \pm 1.4$ & $4.5 \pm 1.3$ & $0.4 \pm 0.9$ & $0.6 \pm 1.1$ \\
\hline & Aged/TX & $11.0 \pm 2.7$ & $25.7 \pm 10.7$ & $0.4 \pm 0.2$ & $3.0 \pm 1.4$ & $-0.01 \pm 0.3$ & $-0.3 \pm 0.5$ \\
\hline \multirow[t]{3}{*}{$(\mathrm{SxB}) \mathrm{F} 1$} & $\mathrm{Yg} / \mathrm{Nl}$ & $46.9 \pm 3.9^{b}$ & $19.6 \pm 2.1$ & $1.5 \pm 0.6$ & $9.2 \pm 2.2$ & $0.2 \pm 0.5$ & $0.3 \pm 0.4$ \\
\hline & Aged/NL & $28.1 \pm 6.4 b$ & $29.2 \pm 11.9$ & $2.6 \pm 1.7$ & $6.6 \pm 1.6$ & $0.1 \pm 0.9$ & $0.1 \pm 0.9$ \\
\hline & Aged/TX & $30.5 \pm 4.7$ & $20.0 \pm 3.7$ & $1.1 \pm 0.3$ & $7.3 \pm 0.7$ & $0.7 \pm 0.7$ & $0.4 \pm 0.4$ \\
\hline
\end{tabular}

a) $\mathrm{NL}=$ normal or sham-hymectomized; $\mathrm{TX}=$ thymectomized. $\mathrm{Yg}$ mice were $4-6$ months, aged mice $20-24$ months old.

b) The difference between the $\mathrm{CD4}^{+} \mathrm{T}$ cells percentages in young and aged mice is significant: $\mathrm{p}<0.0001$ for both strains.

c) Giwen $n$ is for CD4/CD8 measurements. For $V \beta$ measurements in these $Y$ g and Aged NL LAFI mice: $n=5$ and $11(\mathrm{~V} / 38)_{4} 7$ and $10(\mathrm{~V} / 33)_{8} 8$ and $16(\mathrm{~V} / \mathrm{3} 17 \mathrm{a})$, respectively. For $\mathrm{V} \beta$ measurements in these $\mathrm{Yg}$ and Aged NL SJL $x$ BALB/c mice: $n=12$ and $12(V \beta B), 11$ and $13(V \beta 3), 11$ and 14 (V/ 17 a), respectively.

The $\mathrm{CD} 4^{+}$to $\mathrm{CD} 8^{+} \mathrm{T}$ cell ratios in $\mathrm{PBL}$ and $\mathrm{LN}$ decreased with age and also showed some differences between strains (Fig. 2). Although in young mice, the distribution of $\mathrm{T}$ cells among PBL and LN differed between these two F1 hybrids, in 20-24 mos old mice the CD4/CD8 ratios were significantly lower than in the young and much more similar in the two strains. Young (SxB) F1, and both parental strains, SIL and BALB/c mice, exhibited $>60 \% \mathrm{~T}$ cells and $<25 \% \mathrm{~B}$ cells (not shown) in their PBL, while young LAF1 mice had only $41 \%$ of T cells (Table 4). There was an age-related decrease in $\mathrm{T}$ cells in all strains examined of $>10 \%$ by 30 mos of age.

\section{Presence of potentially self-reactive $T$ cells in the peripheral blood from very old mice}

The PBL of these mice was also examined for the presence of $T$ cells that normally undergo deletion in these strains, such as $V \beta 3^{+}, V \beta 11^{+}$and $V \beta 17 \mathrm{a}^{+} T$ cells (Table 4). Escape of $T$ cells bearing these "forbidden" V $\beta$ s was rarely seen in 18-24 mos old mice. For V $\beta 3$ and V $\beta 11$, where $\geq 1 \%$ was considered high, $60 \%$ of $20-24$ mos old (SxB) F1 mice exhibited $\geq 1 \% \mathrm{VB} 3$, but none of the LAF1 or BALB/c mice showed escape for VB11 or VB3 at that age. In 30 mos old BALB/c mice, however, the overall percentage of ${\mathrm{V} B 11^{+}}^{\mathrm{T}}$ cells was significantly higher than in young mice. The presence of $>2 \%$ of $V B 17 \mathrm{a}^{+} \mathrm{T}$ cells in the peripheral blood was seen in only $<10 \%$ of 2-6 or 20-24 mos old (SxB) Fl or LAFI mice, but in 70\% of 30-36 mos old (SxB) F1 mice and in $33 \%$ of 30 mos old LAFI mice. This increase between the ages of $20-24$ and $30-36$ months was 
highly significant $(\mathrm{p}=0.002)$. The intensity of staining with anti-VB17a was somewhat lower in the aged $F 1$ mice than in young SIL mice, suggesting that these cells were $T$ cells with intermediate TCR expression. We have no information concerning the responsiveness to anti-V $\beta$ stimulation of the VB17a ${ }^{+} \mathrm{T}$ cells in PBL from very old mice owing to the low numbers of such cells available for study.
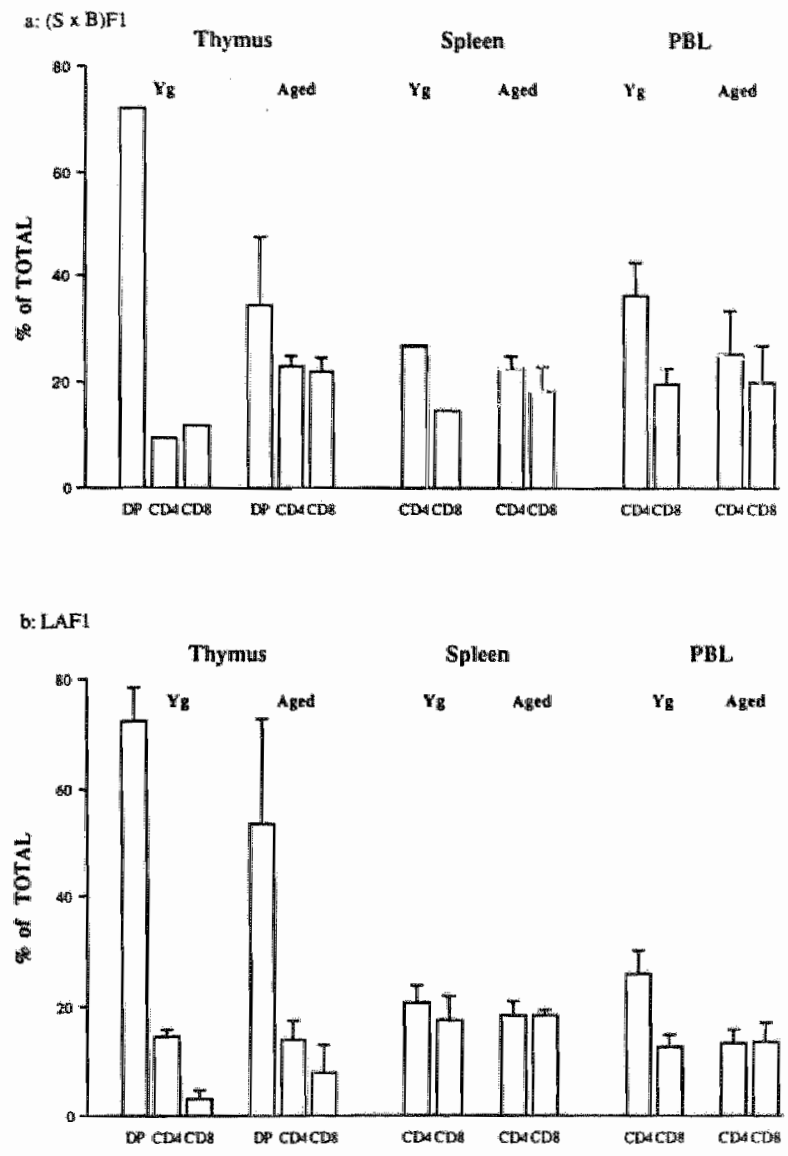

Figure 1: Effect of age on the percentages of $T$ cell subseis in lymphoid tisisues. Mononuclear cells from thymus, spileen and PBL cells were obtained from young and aged (SxB) F1 (a) or LAFI (b) mice. Samples were double stained with anti-CD4-PE and anti-Ly2-YTTC. $\mathrm{n}=2-3$ for spleen and thymus, and 6-17 for PBL. The vifferences between the percentages of $\mathrm{CD} 4^{*} \mathrm{~T}$ cells in PBL of young and aged mice are significant: $p=0.01$ for (SxB) $\mathbb{P 1}$ and p $<0.0001$ for LAF1 mice. 


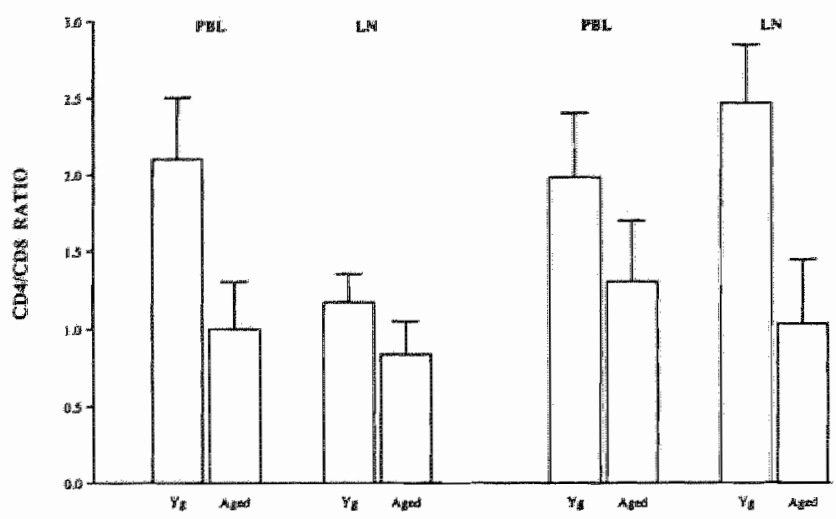

Figure 2: Age-related decrease of CD4/CD8 ratios. The ratio of the percentages of $\mathrm{CD}^{*}$ and $\mathrm{CD} 8^{*} \mathrm{~T}$ cells in $\mathrm{PBL}$ and $L N$ are represented for young ( $2-3$ mos old) and aged (20-24 mos old) (SXB) FI and LAF1 mice. LAFI LN, $n=9$ (Yg) and $20(\mathrm{Aged}) ; \mathrm{PBL}, \mathrm{n}=17$ (Yg) and $15(\mathrm{Aged}) ;(\mathrm{S} \times \mathrm{B}) \mathrm{F}, \mathrm{LN}, \mathrm{n}=14(\mathrm{Yg})$ and 16 (Aged); PBL, $\mathrm{n}=6$ (Yg) and 11 (Aged).

However, we did examine the $\mathrm{CD} 4 / \mathrm{CD} 8$ ratios within the $\mathrm{V} \beta 3^{+}$and $\mathrm{V} \beta 17 \mathrm{a}^{+} \mathrm{T}$ cell subpopulations to determine whether the occasional increase in their percentages in aged mice was primarily due to the $\mathrm{CD}^{+}$or $\mathrm{CD} 8^{+} \mathrm{T}$ cell subset. The $\mathrm{CD} 4 / \mathrm{CD} 8$ ratios of the $\mathrm{V} \beta 3^{+}$or $V \beta 17 \mathrm{a}^{+} \mathrm{T}$ cells found in a few representative $20-24$ months old $(\mathrm{S} \times B) \mathrm{F} 1$ mice with higher than background levels of these cells were higher than the overall $\mathrm{CD} 4 / \mathrm{CD} 8 \mathrm{~T}$ cell ratios at that age (see footnote Table 4). These data suggest that the increase in "forbidden" $\mathrm{T}$ cells in these mice is preferentially in the $\mathrm{CD}^{+} \mathrm{T}$ cell subset as also shown in Fig. 3. On the other hand, when VB17a ${ }^{+}$ $T$ cells were detected at the $1-2 \%$ level in young or $20-24$ months old $\mathrm{LAF}_{1}$ mice, their $\mathrm{CD} 4 / \mathrm{CD} 8$ ratios were 0.6 fold that for the overall $\mathrm{T}$ cell population in $\mathrm{PBL}$ at the same age. Thus, when deletion was occurring normally, the CD4/CD8 ratio tended to be low.

It was of interest to determine whether thymectomy would affect the appearance of "forbidden" $T$ cells. As discussed above, the LNs from the aged TX mice rarely exhibited any $\mathrm{CD}^{+}$or $\mathrm{CD} 8^{+}$ $\mathrm{V} \beta 17 \mathrm{a}$ or $\mathrm{V} \beta 3$ bearing $\mathrm{T}$ cells. The PBL of $\mathrm{LAF} 1$ mice was examined 1.5 and 9 mos following thymectomy. At 1.5 mos the TX mice exhibited $0.53 \pm 0.09(n=4) \vee \beta 17 \mathrm{a}^{*} \mathrm{~T}$ cells, as compared to $0.59 \pm 0.1$ in sham TX mice. At 9 mos these values were $0.97 \pm 0.26(0 / 8>2 \%)$ in TX mice as compared to $1.3 \pm 0.42(0 / 5>2 \%)$ in sham-TX mice. The PBL from older TX mice were not examined.

If the T cell education process in the thymus from aged mice is defective with respect to the deletion of self-reactive cells, an enhanced rate of $\mathrm{T}$ cell production such as occurs during recovery from g-irradiation, might bring "forbidden" $T$ cells into the periphery. In an additional experiment, therefore, $12-15$ mos old LAF1 and (SxB) F1 mice were examined for the appearance of $V \beta 17 a^{4} \mathrm{~T}$ cells in their PBL before and one month after exposure to 300 rads whole body $\mathrm{g}$ irradiation. No increase in $V \beta 17 \mathrm{a}^{+} \mathrm{T}$ cells was detected in any of these animals $(\mathrm{n}=8)$. 
Table 4

Presence of potential self-reactive $T$ cells in the peripheral blood of aged mice

\begin{tabular}{|c|c|c|c|c|}
\hline Mouse strain & Age & Mean percen & tage $\pm S D(n)$ of total $p$ & ripheral blood cellis \\
\hline & & T cells* & $\mathrm{VB17a}(>2 \%)^{7}$ & VB3 or $11(>1 \%)^{8}$ \\
\hline SIL & $2-3$ & $72.8 \pm 4.8(7)$ & $7.5 \pm 3.2(15 / 15)$ & $6.4 \pm 4.3(3 / 3)$ \\
\hline$S J L \times B A L B / C \mathbb{F} 1$ & $2-6$ & $62.1 \pm 8.2(10)$ & $0.1 \pm 1.1^{\mathrm{a}}(1 / 15)^{\mathrm{b}}$ & $-0.1 \pm 0.5^{c}(0 / 6)^{d}$ \\
\hline SJL $\times \mathrm{BALB} / \mathrm{CF} l^{\mathrm{E}}$ & $20-24$ & $46.3 \pm 14.3 \quad$ (9) & $0.9 \pm 0.6(1 / 12)$ & $1.3 \pm 0.5 c(6 / 10) d @$ \\
\hline SJL $x$ BALB/c Fl & $30-36$ & $51.0 \pm 23.6 *(5)$ & $4.3 \pm 4.8^{\mathrm{a}}(11 / 16)^{\mathrm{b} @}$ & $\mathrm{ND}$ \\
\hline BALB.B & 2 & $74.6 \pm 4.3 *(3)$ & $\mathrm{ND}$ & $74.6 \pm 4.3 *(3)$ \\
\hline $\mathrm{BALB} / \mathrm{c}$ & 2 & $60.2 \pm 13.0 *(3)$ & $\mathrm{ND}$ & $60.2 \pm 13.0^{*}(3)$ \\
\hline $\mathrm{BALB} / \mathrm{c}$ & 18 & $51.4 \pm 16.3 *(4)$ & $\mathrm{ND}$ & $0.4 \pm 0.2^{*}(0 / 4)$ \\
\hline $\mathrm{BALB} / \mathrm{c}$ & 30 & $47.1 \pm 14.7 *(3)$ & ND & $1.4 \pm 0.5$ k 3 e $(2 / 3)$ \\
\hline LAFI & $4-6$ & $41.4 \pm 5.4(15)$ & $0.7 \pm 0.5^{f}(0 / 17)$ & $-0.3 \pm 0.3(0 / 5)$ \\
\hline LAF1 & $20-24$ & $30.7 \pm 8.1(26)$ & $0.8 \pm 0.6 \quad(1 / 29)$ & $-0.02 \pm 0.1(0 / 8)$ \\
\hline LAF 1 & 30 & $28.5 \pm 8.1 *(3)$ & $3.6 \pm 4.0^{f}(1 / 3)$ & $0.2 \pm 0.1 *(0 / 3)$ \\
\hline
\end{tabular}

* Determined with anti-Ly-1, all the others were done with anti-Thy-1.

\# Incidence of mice exhibiting $>2 \% \mathrm{VB} 17 \mathrm{a}^{*}$ cells in PBL in parentheses.

$\$$ Incidence of mice exhibiting $>1 \%$ of this $V B$ bearing cells in parentheses.

* VB11, all the others in this column are VB3.

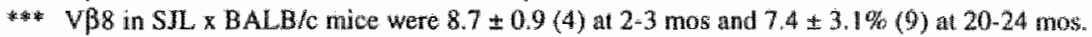

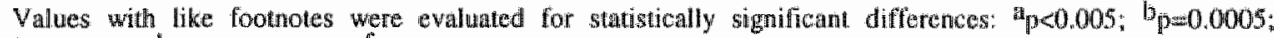

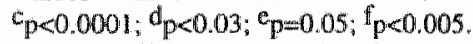

(a) The CD4/CD8 ratios of VP17a $\mathrm{T}$ cells examined in 3 of the $30-36$ mos old mice exhibiling $>2 \%$ WP17a $\mathrm{T}$ cells were $1.4,2.0$ and 68 . These ratios for V $33^{*}$ cells in $20-24$ mos old mice exhibiting $>1 \%$ v $\$ 3^{+}$T eells were

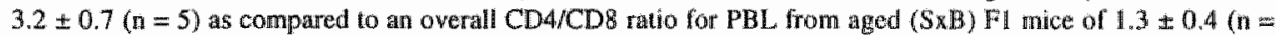
11).

\section{Discussion}

In previous studies V $\beta$ distribution among CD4 cells was not found to change with age, neither at the mRNA level 3 nor at the VB\% staining level ${ }^{34}$. In the present studies, when analyzing mice of two years old or younger, expression of "forbidden" V $\beta$ bearing $C D 4^{+}$or $\mathrm{CD}^{+} \mathrm{T}$ cells was quite rare. Few mice showed staining for $>1 \%$ VP3 or $>2 \% \mathrm{VP17}$ a in CD4 and/or CD8 ${ }^{4} \mathrm{~T}$ cells in LN. Similarly, staining in peripheral blood for these T cells was essentially negative in $20-24$ mos old mice with the exception of VB3 in (SxB) F1 mice, where $60 \%$ of the mice showed low but 
mice with the exception of VP3 in (SXB) Fl mice, where 60\% of the mice showed low but detectable staining above the background established in young mice. Russo et al ${ }^{35}$ reported a similar slight increase in VP3 and VP11 staining in spleen cells in 18-22 mos old as compared to young $B A L B / C$ mice.
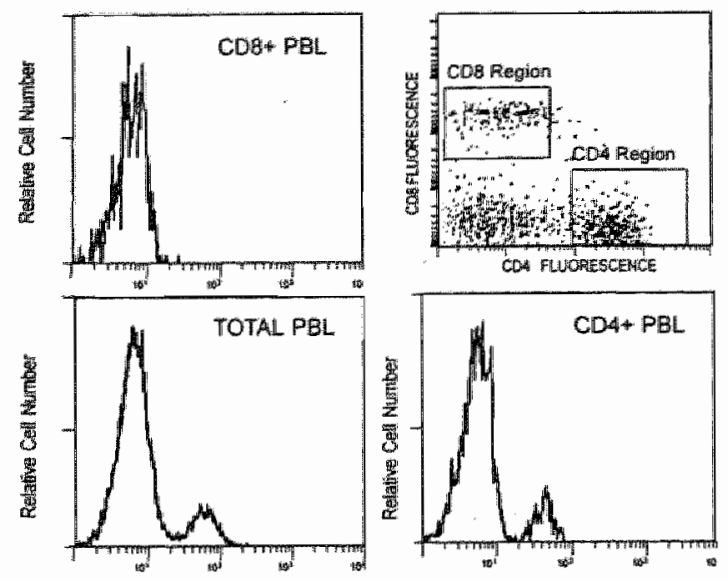

\section{VB17 F FLUORESCENCE INTENSITY}

Figure 3: V 1 175 expression by $\mathrm{CD} 4^{*} \mathrm{~T}$ cells from a 30 mos old $(\mathrm{S} \times \mathrm{B}) \mathrm{F} 1$ mouse. The upper right panel shows a correlated histogtam of the staining of $\mathrm{CD} 4^{*}$ and $\mathrm{CD} 8^{*} \mathrm{~T}$ cells in the PBL. Regions were drawn to identify single positive T-cells and these were used as electronic gates to analyze the expression of V $817 \mathrm{a}$ by the two subsets. Expression by $\mathrm{CDS}^{*} \mathrm{~T}$ cells is shown in the histogram on the upper left and expression by $\mathrm{CD} 4^{+} \mathrm{T}$ cells is shown in the histogram on the lower right. V $\beta 17$ a expression by these subsets can be compared with that of ungated PBL shown in the panel on the lower left.

There are many differences between the design of the present study and those reported by others. Gonzallez-Quintial and Theofilopoulos ${ }^{3}$ determined mRNA levels in pooled RNA from spleen. An occasional aged mouse with higher levels for VB3 or VB1 1 might have been obscured because of the pooling. In addition, they looked at spleen, while we analyzed individual mouse LNs and PBL by staining for protein. Callahan et al. ${ }^{34}$ enumerated $C D 4^{+}$and $C D 8^{+} V \beta \mathrm{T}$ cells in PBL, spleen and LN, but primarily focused their attention on the non-deleted $T$ cell populations. Monoclonal increases in $\mathrm{CD} 8^{+} \mathrm{T}$ cells were seen in the aged mice, as have also been observed in man $^{36}$, but no mention was made of any such population bearing "forbidden" VPs. In contrast to the 20-24 mos old, in the few mice of 30-36 months of age available for the present study, a significant increase in VB17a ${ }^{+}$T cells was observed in both (SxB) F1 and LAF1 mice. Similarly, 30 mos old but not 18 mos old BALB/c mice exhibited staining above the young mouse background for $\mathrm{V} \beta 1 \mathrm{I}^{+} \mathrm{T}$ cells. Where examined in more detail, the CD4/CD8 ratios of the VB17 $\mathrm{a}^{+}$cellls in aged $(\mathrm{S} \times \mathrm{B}) \mathrm{F} 1 \mathrm{mice}$ was variable, but high as compared to the overall $\mathrm{CD} 4 / \mathrm{CD} 8$ ratios in aged mice.

As also previously observed ${ }^{34}$, there was a major age related decrease in peripheral $\mathrm{CD} 4^{+} \mathrm{T}$ cells in all organs examined. Expressed on a percentage basis the decrease in CD4 ${ }^{*} \mathrm{~T}$ cells was much greater than in $\mathrm{CD}^{+} \mathrm{T}$ cells, resulting in marked shifts in $\mathrm{CD} 4 / \mathrm{CD} 8$ ratios, particularly in $\mathrm{LN}$ and 
PBL. This effect was greater in LAFI than in (SxB) Fl mice. In contrast, age related change in the thymus with respect to a decrease in CD4 CD8* cells was much more marked in $20-24$ mos ald (SxB) FI than in LAF1. Extrathymic $T$ cell production in the liver is known to become relatively more prominent in aged than in young athymic mice ${ }^{17}$. These cells are said to appear also in the periphery and consist primarily of a $\mathrm{CD} 4^{-} \mathrm{CD} 8 \mathrm{CD} 44^{*} \mathrm{~T}$ cells $\mathrm{s}^{17}$. However, populations of $\mathrm{CD} 4^{-} \mathrm{CD} 8^{-}$and $\mathrm{CD} 4^{+} \mathrm{NK} 1.1^{*} \mathrm{~T}$ cells have also been reported as of extrathymic $\operatorname{arigin}^{37.38}$ and to be responsible for allogeneic bone marrow graft rejection in athymic mice. Detailed analysis of the VB repertoire of such extrathymic $T$ cells has not been reported. The lack of class $\mathbb{I}$ restriction of $\mathrm{CD} 4^{+} \mathrm{NK} 1.1^{*} \mathrm{~T}$ cells, as shown by their presence in class II deficient mice ${ }^{39}$, suggests that their repertoire may be different from the normal $\mathrm{CD} 4^{+} \alpha \beta \mathrm{T}$ cells. In comparing hepatic $T$ cells with IEL from normal BALB/c mice, Murosaki et al. ${ }^{40}$ found that SEAresponsive $\mathrm{VB11^{+ }}$, but not $\mathrm{VB3}^{+} \mathrm{T}$ cells were present in the hepatic population, whereas both $V \beta 3^{*}$ and $V \beta 11^{+} \mathrm{T}$ cells from the IEL responded. Moreover, the hepatic $V \beta 11^{+} \mathrm{T}$ cells were $\mathrm{CD}^{+}$or $\mathrm{CD} 8^{+}$, while the IEL were typical CD $\alpha \alpha \alpha^{*} \alpha \beta$ cells. Thus, forbidden $V \beta$ cells responsive to stimulation with superantigen, may be found in both these extrathymic $T$ cell populations.

The responsiveness observed in LNs from occasional aged mice, particularly from TX aged mice in the present study, is more likelly to be due to $\mathrm{T}$ cells of extrathymic origin than to $\mathrm{T}$ cells that escaped the deletion process in the thymus. While in rare instances $\mathrm{CD} 4^{+}$or $\mathrm{CD} 8^{+} \mathrm{T}$ cells bearing the relevant $V \beta$ were found that could have been responsible for the responses to anti-V $\beta 3$ and anti-V $\beta 17 \mathrm{a}$, in most cases such cells were not detectable above background. In addition, the increased responsiveness in $L N$ and spleen from TX mice, in which increased DN T cells bearing the relevant V $\beta$ were frequently present, is in agreement with this interpretation. Whether these cells originated in the liver or in the intestines is not clear, but it has been noted by others that the extrathymic $\mathrm{T}$ cells of hepatic origin are prone to appear in peripheral lymphoid tissue from aged mice $^{17}$, while IELs are not likely to appear in peripheral lymphoid tissue ${ }^{8}$.

It is clear that the thymus in both $20-24$ mos old (SxB) F1 and LAFI mice is involuted, allthough we found the decrease in the percentage DP' cells to be much greater in the (SxB) F1 than in the LAFI mice. It is possible, however, that involution accompanied by decreased MHC class II expression on dendritic cells in the medulla, such as described in CsA treated rats ${ }^{25}$, would occur only in the very old mice. Therefore, we cannot exclude the possibility that the $T$ cells bearing forbidden $V \beta$ (primarily $C D 4^{+}$) seen in $\mathrm{PBL}$ from very old mice are of thymic origin and represent a real "escape" from the deletion process. On the other hand, a progressive increase in $\mathrm{CD}^{*}$ "forbidden" VB bearing $\mathrm{T}$ cells of hepatic origin also cannot be excluded. The responsiveness and other staining characteristics of the CD4 $4^{+} V \beta 17 \mathrm{a}^{*} \mathrm{~T}$ cells in PBL from very old mice still need further study.

\section{Acknowledgements}

The expert assistance of Betty Tomasello and John Leu is gratefully acknowledged. 


\section{References}

1 Gotterman SRS - T cell function in Aging - an update. Publisher Liss AR, Inc "New York. Rev Biol Res in Aging, 1987; 3:950127. Ed Adler WH

2 Weksler M - Senescence of immune system. In: The Blology of Immunologic Disease. Dixon FJ and Fisher DW, eds Sinauer Associates, Inc, Sunderland, MA, 1983; 195-306.

I Gonzalez Quintial $R$ and Theofflopoulos AN .VB gene repertoires in aeging mice. J Immunol, 1992; 149:230.

* Stutman O - Postthymic T-cell dewelopment, Immunol Rev, 1986; 91:159.

s MacDonald HR, Lees RK, Bron $C$, Sordat B and Miecher $G-T$ cell antigen recepior expression in athymic (nu/nu) mice. Evidence for an oligoclonal $\beta$ chain repertoire. J Exp Med, 1987; 166:195.

6 Rocha $\mathrm{B}$ - Characterization of VP-bearing cells in athymic (nu/nu) mice suggests an extrathymic pathway for $\mathrm{T}$ cell differentiation. Eur J Immunol, 1990; 29:919.

7 Guy-Grand $D_{*}$ Cerf-Bensussan $N_{*}$ Balissen B, Malsassis-Seris $M$, Bricotet $C$ and Vassalli $P$. Two gut intraepithelial $\mathrm{CD} 8^{*}$ lymphocyte populations with different $\mathrm{T}$ cell receptors: $\mathrm{A}$ role for gut epithelium in $\mathrm{T}$ cell differenciation. J I Exp Med, 1991: 173:471.

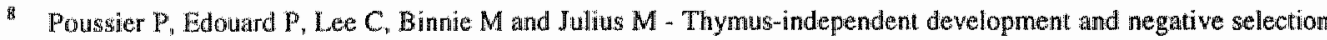
of T $T$ cells expressing $T$ " cell receptor $\alpha / \beta$ in the intestinal epithelium: Evidence for distinct circulation patterns of gut and thymusderived T lymphocyter. J Exp Med, 1992; 176:187.

2 Rocha B. Vassalli $P$ and Guy-Grand D - The V $B$ repertoire of mouse gut homodimeric CD8 intraepithelial T cell receptor $\alpha / \beta^{*}$ lymphocytes reveals a major extrathymic pathway of $\mathrm{T}$ cell differentiation. J Exp Med, 1991; $173: 483$.

10. Ohteki "T', Seki S, Abo T and Kumagai $\mathrm{K}$ - Liver is a possible site for the proliferation of abnormal $\mathrm{CD}^{*}{ }^{*} \mathrm{C}^{-}$ double-negative lymphocytes in autoimmune MRL-lpr/lpr mice. J Exp Med, 1990; 172:7.

11 Ohteki T, Abo T, Seki $\$$, Kobata T, Yagita $\mathbb{H}$, Okunura $\mathrm{K}$ and Kumagai $\mathrm{K}$ - Predominant appearance of gamma/delta T lymphocytes in the liver of mice after birth. Eur J Immunol, 1991;21:1733.

12 Mosley RL and Klein JR - Peripheral engraftment of fetal intestine into athymic mice sponsors. $T$ cell development: Direct evidence for thymopoielic function of murine small intestine. J Exp Med, 1992; 176:1365.

13 Lin $T$, Matsuzaki $G$, Kenai $H$, Nakamura $T$ and Nomoto $K$ - Thymus influences the development of extrathymically derived intestinal intraepithelial lymphocytes. Eur J Immunol, 1993; $23: 1968$.

14 Smith H, Ming Chen I, Kubo R and Tung KSK - Neonatal thymectomy results in a repertoire enriched in T cells deleted in adult thymus, Science, 1989: $245: 749$.

1. Abo T, Ohteki $T$, Seki $\$$, Koyamada $N_{1}$ Yoshikai $Y$, Masuda $T$, Rikoishi H and Kumagai $K$ - The appearance of $T$ cells bearing self-reactiwe T cell receptor in the livers of mice injected with bacteria. JExp Med, 1991; 174:417.

16 Poussier P. Teh HS and Julius M - Thyrnus-independent positive and negative selection of T cells expressing a major histocompatibility complex class II restricted transgenic T cell receptor alpha/b in the intestinal epithelium. J Exp Med, 1993; 178:1947.

17 Ohteki $T$, Okuyama $R_{\text {, Seki }} S$, Abo T, Sugiura $K$, Kusumi $A$, Ohmori $T$, Waranabe $H$ and Kumagai $K$ - Agedependent incrense of extrathymic $T$ cells in the liver and their appearance in the periphery of older mice. $J$ Inmunot, 1992; 149:1562.

18 MacDonald HR, Lees RK, Sordat B, Zaech P, Maryanski $\mathrm{NL}$ and Biren $\mathrm{C}$ - Age-associated increase in expression of the $T$ celll surface markers Thy 1 , Lyt 1 , and Lyt-2 in congenitally athymic (nu/nu) mice: analysis by flow microfluotometry. Il limmunol, $1981: 126: 865$.

19. Viney J, MacDonald TT and Spencer J - Gammaddelta T cells in the gut epithelium. Gut, 1990; 31:841

20 Mosley RL, Styre D and Klein JR - Differentiation and functional maturation of bone marrow-derived intestinal epithelias $T$ cells expressing membrane $T$ cell receptor in athymic radiation chimeras. J Immunol, 1990; 145:1369.

21 Danoisenux JGMC, Beijleveld LJJ and wan Breda Vriesman PJC - The effects of in vivo cyclosporin A administration on rat thymic dendritic cells. Clin Exp Immunol, 1994; $96: 513$. 
2 Glazier A, Tutschka PI, Farmer ER and Santos GW - Graft-wersus-host disease in cyclosporin A-treated rats after syngeneic and antologous bone marrow reconstitution. J Exp Med, 1983; 158:1.

23. Jenkins MK, Schwartz RH, Pardoll DM - Effects of cyclosporin A on T cell dewelopment and clonal deletion. Science, $1988 ; 241: 1655$.

24 Bucy RP, XU XY, Li I and Huang GQ - Cyclosporin A-induced autoimmune disease in mice. I Immunol, 1993; 151:1039.

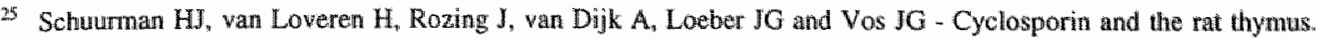
An immunohistochemical study. Thym, 1990; 16:235.

26 Farr AG and Sidman CL - Reduced expression of Ia antigens by thymic epithelial cells of aged mice. J Imununol, $1984 ; 133: 98$

27 Belsito DV, Epstein SP, Schultz JM, Baer RL and Thorbecke GI - Enhancenent by various cytokines or 2-beta mercaptoethanol of Ia antigen expression on Langerhans cells in skin from nomal aged and young mice: Effect of cyclosporine Am I Immunol, 1989; 143:1530-1536.

23 Tung KSK, Smith S, Tuescher C, Cook C gnd Anderson RE - Murine autoimmune oophoritis, epididynoorchitis, and gastritis induced by day 3 thymectomy. Immunopathol Am J Path, 1987; 126:293.

29 Kappler JW, Wade T, White J, Kushnir E, Blackman M, Bill J, Roehm N and Marrack P - A T cell receptor VB segment that imparts reactivity to a ciass II major histocompatihility complex product. Cell, 1987; 49:263

30 Pullen AM. Marrack P and Kappler JW - The T-cell repertoire is heavily influenced by tolerance to polymorphic self-antigens. Nature, $1988 ; 335: 796$.

31 Kanagawa $\mathrm{O}$ - Antibody-mediated activation of $\mathrm{T}$ cell clones as a method for screening hybridomas producing antibodies to the $T$ cell receptor. J Immunol Meth. 1988; 110:169.

32 Bill J, Kanagawa $\mathrm{O}$, Woodland DL and Palmer $\mathrm{E}$ - The MHC molecule I-E is necessary but not sufficient for the clonal deletion of $\mathrm{V}$ beta 11-bearing T cells. J Exp Med ${ }^{2}$ 1989; 169:1405.

33 Gutierrez-Ramos JC. Andreu JL, Rewilla Y, Vinuela E and Martinez AC - Recovery from autoimmunity of MRL/lpr mice after infection with an interleukin-2/vaccinia recombinant virus. Nature (Lond), 1990; 346:371.

${ }^{34}$ Callahan JE, Kappler JW and Marrack P - Unexpected expansions of CD8-bearing cells in old mice. J Immunol, $1993 ; 151: 6657$.

35 Russo C, Cherniack EP, Wali A and Weksler ME - Age-dependent appearance of non-major listocompatibility complex-restricted helper T cells. Proc Natl Acad Sci, 1993; 90:11718.

36 Posnett DN, Sinha R, Kabak $S$ and Russo $C$ - Clonal populations of $T$ cells in normal elderly humans: the $T$ cell equivalent to "benign monoclonal gammopathy". J Exp Med, 1994; 179:609.

37 Arase $H$. Arase $N$, Ogasawara $K_{*}$ Good RA and Onoe $K$. An NkI I CD4 8 single-positive thymocyte subpopulation that expresses a highlly skewed T cell antigen receptor VB ramily. Proc Nall Acad Sci USA, 1992; 89:6505.

38 Kikly $\mathrm{K}$ and Dennen $\mathrm{G}$ - Evidence for extrathymic development of TNK cells. $\mathrm{NK}^{+} \mathrm{CD}^{*}$ cells responsible for acute marrow graft rejection are present in thymus-deficient mice. J Immunol, 1992: 149:403.

39 Cosgrove D, Gray D, Dierich A, Kaufman J, Lemeur M, Benoist C and Mathis D - Mice lacking MHC Class II molecules. Cell, 1991; 66:1051.

40 Murosaki $S$, Yoshikai Ishida A, Nakamura T, Matsuzaki G. Takimoto H, Yuuki H and Nonoto K - Failure of T cell receptor $\gamma \beta$ megative selection in murine intestinal intra-epithelial lymphocyles. Int Immunol, $1991 ; 3: 1005$. 



\section{Chapter \\ 4}

\section{Tolerogenic forms of auto-antigens and cytokines in the induction of resistance to experimental allergic encephalomyelitis}

L Santambrogio*, Crisi* GM, Leu J, Hochwald** GM, Ryan* T and Thorbecke* GJ

Depts. of Pathology*, Neurology "Physiology and Neurosciences* and Kaplan Comprehensive Cancer Center, New York University School of Medicine, New York, NY 10016 


\section{Summary}

Resistance to EAE induction by homogenized myelin (MSCH) in complete Freund's adjuvant (CFA) and pertussigen (P) in SJL mice was seen one week after intravenous injection of PLP 139-151 coupled to spleen cells (PLP-ECDI-SP). Although this resistance could be transferred by spleen cells enriched for $\mathrm{CD} 8^{+} \mathrm{T}$ cells and thus had a component of immunoregulatory $\mathrm{T}$ cells, it was primarily due to anergy, as it was reversible by four daily injections of $\mathbb{L}-2$ starting three days after the PLP-ECDI-SP. Earlier treatment with IL-2 did not reverse the tolerance. In view of the known higher sensitivity to anergy induction of Th1 than of Th2 cells, a change in the cytokine balance in the response to MSCH + CFA after anergy induction might be responsible for the resistance to EAE induction. The effect of treatment with cytokines alone on induction of EAE was therefore also determined. Short term (1-2 weeks) daily pretreatment with IL-2 (4000 $\mathrm{U})$ or TGF- $\beta_{2}(1 \mathrm{mg})$ somewhat decreased the susceptibility to subsequent EAE induction, but IL-4 (5 ng), IL-10 (5 mg) or IL-12 (50-200 ng) had no effect under those conditions, even if low doses of PLP were injected simultaneously. Daily injections of IL-4 over an eight week period prior to immunization, howewer, significantly lowered the incidence of EAE. Simultaneous injections of IFN- $\gamma(2000 \mathrm{U} /$ day) completely abolished this effect of $\mathrm{IL}-4$.

The effect of these cytokines administered immediately after the immunization with MSCH + CFA $+P$ was also examined. As shown earlier, TGF $\beta_{2}(100-1000 \mathrm{ng} /$ day $)$ caused a marked protection when it was given ip on days 5-9 after injection of MSCH + CFA. $\mathbb{L}-4(5 \mathrm{ng} / \mathrm{day})$, in contrast, was very protective when administered on days $0-4$ and less so when given on days 5-9 or even on days 0-12. $\mathrm{LL}-10(1 \mathrm{mg} /$ day) was not protective under these conditions and $\mathrm{LL}-12$ (50 $\mathrm{ng} / \mathrm{day})$ significantly increased the severity and mortality of $\mathrm{EAE}$ when given on days $0-4$ after $\mathrm{MSCH}+\mathrm{CFA}$.

\section{Introduction}

Three mechanisms have been proposed to explain the failure to respond immunologically to self antigens, including deletion, non-responsiveness (anergy) and active suppression of auto-reactive $\mathrm{T}$ and/or $\mathrm{B}$ cell clones ${ }^{1,2,3,4}$. In addition, some auto-antigens may be hidden from the immune system because they are only expressed in a privileged site such as the brain, which is not subject to intense immune surveillance. Experimental allergic encephalomyelitis (EAE) is a $\mathrm{T}$ cell mediated autoimmune disease in which myelin specific antigens, such as myelin basic protein (MBP) and proteolipid protein (PLP), are recognized by auto-reactive $\mathrm{CD} 4^{+*} \mathrm{~T}$ lymphocytes after immunization with the auto-antigen in complete Freunds adjuvant ${ }^{5,6}$. The disease is characterized by infiltration with inflammatory cells and demyelination of brain and spinal cord ${ }^{7,8,9}$.

Previous studies have shown that the injection of MBP or PLP-coupled splenocytes protects against the subsequent development of actively or passively induced acute and relapsing $\mathrm{EAE}^{10,11,12,13,14}$. Such protection is antigen specific ${ }^{15,16}$. It has been postulated that this resistance to EAE induction is due to anergy of MBP or PLP reactive $T$ cells, because tolerant mice also fail to develop proliferative responses and delayed type hypersensitivity to myelin antigens ${ }^{15}$. It is known from studies on T cell anergy in vitro that $I-2$ can release cells from anergy induced by an 
antigen presented in the absence of co-stimulating factors ${ }^{17}$. Anergic T cells fail to produce $\mathrm{L}-2$ in response to antigen, although they possess $\Pi L-2$ receptors and are capable of responding to added $\mathrm{IL}-2$ by proliferation ${ }^{18}$. Therefore, reversal of tolerance by $\mathrm{IL}-2$ can be used to differentiate anergy from deletion of antigen-specific $T$ cells.

Another mechanism of tolerance to self is that of $T$ cell mediated suppression in which the autoreactive lymphocytes are held in check by antigen specific immunoregulatory $T$ cells or factors deriwed from them. Such cells appear to be present in both rats and mice recovering from $\mathrm{EAE}^{19,20,21}$. These cells are also generated after tolerance induction by oral administration of $\mathrm{MBP}^{22,23,24}$.

Recent observations raise the possibility that cytokine regulation plays a role in the resistance to autoantigen induced forms of autoimmune diseases. It is known that different cytokines are able to direct the differentiation of antigen or mitogen stimulated Th0 cells in witro towards either the Th1 or the Th2 phenotype (reviewed in ${ }^{25}$ ). In addition, anergy is readily induced in IL-2 and IFN$\gamma$ secreting (Th1) clones, and not in $\mathbb{L}-4, \mathbb{L}-5$, and $\mathbb{I L}-10$ secreting (Th2) clones ${ }^{26,27}$. In the resistance to infections by parasites, it thas been shown that the injection of cytokines in vivo can dramatically alter the course of the disease ${ }^{28,29}$. The most important cytokines examined so far in this regard are $\mathrm{IL}-4, \mathrm{IFN}-\gamma, \mathrm{IL}-12$ and $\mathrm{IL}-10$. In such experiments, the foreign antigen is injected simultaneously with the immune modulating cytokine. It could be argued that responses to autoantigens might be influenced by cytokines even without exogenous administration of the autoantigen.

In the present studies, we have reinvestigated the mechanism of tolerance induced by iv injection of PLP 139-151, one of the major encephalitogenic peptides in SJL mice ${ }^{5}$, coupled to spleen cells. It will be shown that $\mathbb{L}-2$ can abrogate this form of tolerance to PLP in vivo. In addition, we show that the reversal of anergy by $\mathbb{I L}-2$ is critically dependent on the time of $\Pi-2$ injection in relation to the induction of tolerance. We also demonstrate that, as in rats ${ }^{30}$, spleen cells taken from mice one week after injection of PLP-coupled spleen cells are able to transfer resistance to EAE induction to naive recipients. Furthermore, we have examined whether immunomodulation by cytokines that affect the Th1 to Th2 cell ratio, with and without injection of PLP, may be used as an additional mechanism to alter the susceptibility of mice to the induction of EAE. We find that, when administered early after immunization, $I L-12$ increases and $\mathbb{L}-4$ decreases the severity of EAE.

\section{Materials and methods}

\section{Mice}

Female SJL/J mice, 4 to 7 wk old, were purchased from the Jackson Laboratories (Bar Harbor, ME). SJL $x$ BALB/c mice were bred and allowed to age in the animal quarters of NYU Medical Center. Paralyzed mice were afforded easy access to food and water. 


\section{Antigens}

Proteolipid protein peptide 139-151 (PLP) was purchased from Immuno-Dynamics Inc. (La Jolla, CA). Murine spinal cords that were obtained by insufflation were rapidly homogenized, lyophilized and kept at $-70^{\circ} \mathrm{C}$ until use (MSCH). SEB was purchased from Toxin Technologies, Inc. (Sarasota, FL).

\section{Induction of EAI}

Mice were immunized with MSCH or PLP in adjuvant as previously described ${ }^{31}$. Each mouse received subcutaneous injections into the hind footpads and nape of the neck with a total of 0.1 $\mathrm{ml}$ of an emulsion containing $0.2 \mathrm{mg}$ M. tuberculosis H37Ra and either $200 \mathrm{mg}$ PLP or $4 \mathrm{mg}$ lyophylized MSCH in CFA (Difco Labs., Detroit, MI). The immunization was followed after 24 and $48 \mathrm{~h}$ by the iv injection of 200-400 ng of pertussigen (LIST Biol. Labs. Inc., Campbell, CA), a biologically active protein from Bordetella pertussis highly active as an adjuvant to promote the induction of $\mathrm{EAE}^{32}$. Clinical signs of EAE developed in 10 to 15 days.

\section{Clinical evaluation}

Mice were observed daily for clinical signs of disease until days 30 to 35 postimmunization. EAE symptoms were scored according to their clinical severity as follows: grade 0 , no symptoms; grade 1, limp tail; grade 2, limb tail and hind limb weakness (waddling gait); grade 3, severe hind limb weakness and mild forelimb weakness; grade 4, total paralysis of hind legs, that may be associated with moderate forelimb weakness; grade 5, complete paralysis and moribund. Mild disease symptoms had to be present for three consecutive days to be considered positive.

\section{Preparation of PLP-coupled splenocytes (PLP-ECDI-SP)}

Splenocytes were coupled with PLP by the method of Miller et al. ${ }^{33}$, using water-soluble 1-ethyl3-(3-dimethyl-aminopropyl)-carbodiimide HCl (ECDI; Calbiochem-Behring Corp., La Jolla, CA). Splenocytes were recovered from total SJL/J spleens after lysis of RBC by hypotonic shock in distilled $\mathrm{H}_{2} \mathrm{O}$. Spleen cells were washed in saline, pelleted in $50 \mathrm{ml}$ centrifuge tubes and incubated at $4^{\circ} \mathrm{C}$ for $30 \mathrm{~min}$ at a final concentration of $2.5 \times 10^{8} \mathrm{cells} / \mathrm{ml}$ in saline containing 1 $\mathrm{mg} / \mathrm{ml}$ PLP 139-151. ECDI was then added to a concentration of $150 \mathrm{mg} / \mathrm{ml}$. Sham-coupled cel.ls (ECDI-SP) were prepared by incubation of splenocytes in saline containing ECDI but no PLP. After a further incubation at $37^{\circ} \mathrm{C}$ for $1 \mathrm{~h}$, the cells were washed three times, resuspended to 30 $60 \times 10^{7} \mathrm{cells} / \mathrm{ml}$ in saline, and kept on ice until injected.

\section{Induction of tollerance and cell transfers}

Mice were injected iv ("Day $-7^{\prime \prime}$ ) into the lateral tail vein with $30-60 \times 10^{6}$ viable ECDI treated or PLP 139-151-ECDI treated spleen cells (ECDI-SP or PLP-ECDI-SP). Some of these mice were immunized 7 days after the injection to assess the degree of tolerance ("Day 0 "). In other experiments, spleen cells were recovered from the tolerized mice 7 days after tolerization. Spleen cells were enriched for $\mathrm{CD} 8^{+} \mathrm{T}$ cells by incubation with $\mathrm{L} 3 \mathrm{~T} 4$ (rat anti-mouse $\mathrm{CD} 4$ ) at $4^{\circ} \mathrm{C}$, followed by non-toxic rabbit $\mathrm{C}$ at $37^{\circ} \mathrm{C}$, and next by panning of the cells at $4^{\circ} \mathrm{C}$ on Goat anti-mig. coated Petri dishes to remove $\mathrm{B}$ cells. Unfractionated spleen cells or $\mathrm{CDB}^{+}$enriched $\mathrm{T}$ cells were 
injected iv into nave mice at $30-60 \times 10^{6}$ viable cells/mouse. Recipients were immunized immediately following the cell transfer ("Day 0 ").

\section{Cytokine treatment}

Mice received $4000 \mathrm{U}$ recombinant human $I L-2$ (Hoffmann-La Roche Inc, Nutley, NJ), $5 \mathrm{ng}$ recombinant murine $\mathbb{I L}-4$ (Schering PLough Research Inst., Kenilworth, NJ), 1-5 mg recombinant human IL-10 (Schering), 50 to 200 ng recombinant murine IL-12 (Hoffmann-La Roche), or 12000 ng recombinant simian TGF- $\beta_{2}$ (human and simian TGF- $\beta_{2}$ have identical amino acid sequences; Celtrix Pharmaceuticals Inc, Santa Clara, CA) intra- peritoneally either before or after induction of tolerance and/or immunization.

The biological half-lives of these cytokines after iv injection for TGF- $\beta, \Pi L-2, I L-4, \Pi L-10$ and IL12 are $2.2 \mathrm{~min}$ (measured in rats), $3.7 \mathrm{~min}$ (in mice), $20 \mathrm{~min}$ (in monkeys), 30 min (in mice) and 5 $\mathrm{h}$ (in mice), respectively (TGF- $\beta:{ }^{34}, \mathbb{L}-2:{ }^{35}, \mathbb{L}-4$ and $\mathrm{L}-10$ : unpublished data Schering PLough Research Inst.; IL-12: M.K. Gately, pers. comm.). The disappearance rate from the blood for these cytokines, where measured, is much slower after ip injection.

\section{Reactivation of EAE}

At the time of resolution of the acute disease (approximately 1 to 2 months after immunization), $40 \mathrm{mg}$ of SEB was injected iv. The mice were observed for development of relapsing disease up to 10 days following the SEB injection. Relapses of EAE usually accurred within 5 days.

\section{Statistical analysis}

Comparison of the mean day of onset and the max score between two groups of mice were analyzed by the Student's $t$ test. Incidences of EAE and of mortality were compared by use of the $\mathrm{Chi}^{2}$ test.

\section{Results}

\section{Effects of mouse age and of cytokines on tolerance induction by PLP-coupled spleen cells.}

Mice tolerized with PLP-ECDI-SP showed a statistically significant ( $\mathrm{p}<0.0001)$ decrease in the incidence and severity of acute EAE as compared with ECDI-SP treated mice (Table 1). The disease incidence and severity in the 15-17 mos old mice was comparable to that seen in $2-4$ mos old SJL $\times$ BALB/C mice (Table 1). Similarly, the protective effect of tolerance induction was obtained in both 2-3 mos and 15-17 mos old SJL $\times$ BALB/c mice. The older mice studied here were $S J L \times B A L B / c$, because SIL mice of that age are not available (they succumb to lymphoma before that age). The administration of IL-2 during the early phase of tolerance induction (days -7 to -4) caused, if anything, a slight increase in the resistance to EAE induction as compared to that induced by PLP-ECDI-SP without $\mathbb{L}-2$. In contrast however, when given in the later phase of tolerance induction (days -4 to -1 ), IL-2 completely abrogated tollerance in the PLP-ECDI-SP treated mice, resulting in EAE incidence, severity and mortality similar to that observed in control 
mice. Thus, rewersal of tolerance induction by IL-2 was effective only when it was given a few days after the tolerogen.

Table 1

Effect of IL-2 on resistance to EAE induction after i.v. injection of PLP-coupled spleen cells

\begin{tabular}{|c|c|c|c|c|c|}
\hline Age & $\begin{array}{l}\text { Pretreatment on } \\
\text { Day }-7^{2}\end{array}$ & $\begin{array}{l}\text { Incidence } \\
\text { of } \mathrm{EAE}\end{array}$ & $\begin{array}{l}\text { Max. Score } \\
\text { of EAE }\end{array}$ & $\begin{array}{l}\text { Mortadity } \\
\text { from EAE } \\
(\%)\end{array}$ & $\begin{array}{l}\text { Day of EAE } \\
\text { Onset }\end{array}$ \\
\hline \multirow[t]{5}{*}{ 2.3 months } & ECDI-SP & $20 / 20$ & $4.3 \pm 1.2 \mathrm{e}$ & $60^{h}$ & $12.9 \pm 0.9^{k}$ \\
\hline & ECDI-SP+ $11-2^{3}$ & $13 / 14 \mathrm{~b}$ & $2.7 \pm 0.6 \mathrm{f}$ & 29 & $13.0 \pm 0.5$ \\
\hline & PLP-ECDI-SP & $6 / 15 a, c$ & $0.5 \pm 0.9 \mathrm{e}, \mathrm{g}$ & $0^{h, i}$ & $15.4 \pm 0.8 \mathrm{k}$ \\
\hline & $\begin{array}{l}\text { PLP-ECDI-SP+IL-2 } \\
\text { Days }-7 \text { to }-4\end{array}$ & $1 / 10^{b}$ & $0.1 \pm 0.3^{f}$ & 0 & 18 \\
\hline & $\begin{array}{l}\text { PLP-ECDI-SP+IL-2 } \\
\text { Days }-4 \text { to }-1\end{array}$ & $5 / 5^{c}$ & $4.2 \pm 1.1 \mathrm{~g}$ & $60^{i}$ & $12.8 \pm 0.8$ \\
\hline \multirow[t]{2}{*}{15.17 months } & ECDI-SP & $5 / 5 d$ & $2.8 \pm 2.0$ & 40 & $12.8 \pm 0.4$ \\
\hline & PLP-ECDI-SP & $1 / 5^{d}$ & 0.4 & 0 & 13 \\
\hline
\end{tabular}

Mice were SJLJ, except the $15-17$ mos ald mice which were SIL $\times$ BALB/c due to the unavailability of aged SIL/J.

2 Day $0=$ Inmunization with spinal cord in CFA. Pertussigen was injected on days 1 and 2.

3 There was no significant difference between control groups of mice receiving 4000 U IL-2/day ip on days -7 to -4 and on days $-410-1$; these groups were therefore taken together.

The significance of differences between groups with respect to EAE incidence and mortality rates were deiermined by $\mathrm{Chi}^{2}$ (est: a) and $\left.\mathrm{b}\right) \mathrm{p}<0.0001 ; \mathrm{c}$ ) and d) $\mathrm{p}<0.05$; h) $\mathrm{p}=0.0002$; i) $\mathrm{p}=0.001$.

Differences if the max. EAE disease scores and in the days of EAE onset between the simillarly footnoted walues were determined by Student's $(t$ test: $0, f), g$ ) and l li) p $<0.0001$.

In control mice injected with ECDI-SP, IL-2 injected together with (days -7 to -4) or a few days after the ECDI-SP (days -4 to -1 ) did not alter the EAE incidence, although it did cause a moderate decrease in $\mathbb{E A E}$ severity and mortality. This protective effect of pretreatment with IL-2 against EAE induction is reminiscent of the effect of IL-2 described by Otten et al. ${ }^{36}$, who found that pretreatment with IL-2 lowered the subsequent responsiveness of cloned T cells to antigen. In other experiments (not shown) the effect of $I L-4$ and of TGF- $\beta$ on tolerance induction by PLPECDI-SP was also examined. In these experiments, control and PLP-ECDI-SP tolerized mice were injected with murine L 4 ( 5 ng/mouse) or TGF- $\beta_{2}$ ( $\left.2 \mathrm{mg} / \mathrm{mouse}\right)$, on days -7 to -4 . Again, virtually complete tolerance was observed in the PLP-ECDI-SP treated mice and this tolerance was not modified by administration of either $\Pi-4$ or TGF- $\beta_{2}$. 
Effect of passive transfer of tolerance by iv injection of spleen cells from PLP.ECDI-SP treated mice

Experiments were done to assess if the PLP-ECDI-SP induced tolerance could be passively transferred. ECDI-SP and PLP-ECDI-SP treated mice were killed 7 days after the tolerance induction.

\section{Table 2}

Transfer of resistance to EAE induction by spleen cells or CD8 enriched T cells to normal SJL mice

\begin{tabular}{llllll}
\hline $\begin{array}{l}\text { Donor } \\
\text { Treatment }\end{array}$ & $\begin{array}{l}\text { Cells } \\
\text { Transferred }\end{array}$ & $\begin{array}{l}\text { Day of EAE } \\
\text { Onset }\end{array}$ & $\begin{array}{l}\text { Incidence of } \\
\text { EAE }\end{array}$ & $\begin{array}{l}\text { Max. Score of } \\
\text { EAE }\end{array}$ & $\begin{array}{l}\text { Mortality } \\
\text { from EAE }\end{array}$ \\
\cline { 1 - 5 } Control Spl & Spleen & $13.0 \pm 0$ & $4 / 5$ & $3.6 \pm 2.1^{\mathrm{a}}$ & $3 / 5 \mathrm{c}$ \\
PLP-Spleen & Spleen & 14 & $1 / 5$ & $0.2 \pm 0.4 \mathrm{~b}$ & $0 / 5 \mathrm{~d}$ \\
Control Spl & $\mathrm{CD} 8^{+\mathrm{T}}$ & $12.6 \pm 0.5$ & $3 / 5$ & $3.0 \pm 2.7 \mathrm{a}$ & $3 / 5 \mathrm{c}$ \\
PLP-Spleen & $\mathrm{CD} 8{ }^{+\mathrm{T}}$ & 14 & $2 / 5$ & $1.0 \pm 1.4 \mathrm{~b}$ & $0 / 5 \mathrm{~d}$ \\
\hline
\end{tabular}

\footnotetext{
* Cell transfer and induction of EAE were on Day 0.

a) These groups, taken together, are significantly different from the two groups labeled,

b) taken together: $\mathrm{p}<0.005$ by Student's t-test.

c) These groups, taken together, are significantly different from the two groups labeled,

d) taken together: $\mathrm{p}<0.01$ by two-tail $\mathrm{Chi}^{2}$ test.
}

The spleens were removed and 30-60 × $10^{6}$ viable unfractionated cells or $\mathrm{CD} 8^{+}$enriched $\mathrm{T}$ cells were injected iv into naive recipients. A few hours after the passive transfer of spleen cells, the recipients were immunized with MHSC in CFA (Table 2). Recipients which received unfractionated or $\mathrm{CD}^{+}$enriched splenocytes from ECDI-SP treated mice showed no resistance against EAE induction. In contrast, the recipients of either unfractionated or $\mathrm{CD} 8^{+}$enriched spleen $T$ cells from PLP-ECDI-SP tolerized mice showed a decrease in the EAE severity and mortality, but no significant decrease in the incidence of EAE development. The results suggest that immunoregulatory $\mathrm{CDB}^{+} \mathrm{T}$ cells develop during the process of tolerization with PLP-ECDISP which exhibit the capacity to interfere with EAE induction. The resistance to EAE induction, observed in 15-17 mos old SJL x BALB/c mice, injected with PLP-ECDI-SP, was also transferred with spleen cells to recipients of similar age. None of the 5 recipients of spleen cells from tolerant donors developed EAE, while $3 / 5$ of control recipients did. (not shown).

\section{Effect of pretreatment with cytokines without antigen on susceptibility to $\mathrm{EAE}$ induction}

The data in Table 1 suggest that pretreatment with $\mathbb{L}-2$ without tolerogen within the week prior to EAE induction, rendered SIL mice less sensitive to EAE induction. 


\section{Table 3}

Effect of TGF- $\beta_{2}$ and IL-4 on susceptibility to EAE induction in SJL mice

\begin{tabular}{|c|c|c|c|c|c|}
\hline $\begin{array}{l}\text { Cytokine } \\
\text { Dose/Day ip }\end{array}$ & $\begin{array}{l}\text { Days of } \\
\text { Treatment }\end{array}$ & $\begin{array}{l}\text { Day of } \\
\text { EAE Onser }\end{array}$ & $\begin{array}{l}\text { Incidence } \\
\text { of } \mathrm{EAE}^{3}\end{array}$ & $\begin{array}{l}\text { Max. Score } \\
\text { of EAE }\end{array}$ & $\begin{array}{l}\% \\
\text { Mortality }\end{array}$ \\
\hline \multicolumn{6}{|l|}{ experiment 1} \\
\hline None & & $11.5 \pm 1.5$ & $15 / 16$ & $4.2 \pm 1.6$ & 75 \\
\hline IL-4, $5 \mathrm{ng}$ & $-14 t p-2$ & $12.3 \pm 2.4$ & $7 / 10$ & $2.8 \pm 2.2$ & 40 \\
\hline $\mathrm{TGF}-\beta, 2000 \mathrm{ng}$ & -14 to -2 & $12.0 \pm 2.0$ & $6 / 10$ & $2.3 \pm 2.4$ & 40 \\
\hline $\mathrm{TGF}-\beta+\mathrm{IL}-4$ & -14 to -2 & $11.6 \pm 1.2$ & $3 / 5$ & $2.2 \pm 2.5$ & 40 \\
\hline $\mathrm{IL}-4$ & -56 to -2 & $12.0 \pm 1.7$ & $3 / 6$ & $2.3 \pm 2.6$ & 33 \\
\hline $\mathrm{IL}-4+\mathrm{IFN}-\gamma^{2}$ & -56 to -2 & $10.7 \pm 1.1$ & $7 / 7$ & $4.6 \pm 1.1$ & 71 \\
\hline \multicolumn{6}{|l|}{ experiment 2} \\
\hline None & & $14.5 \pm 3.9$ & $13 / 13$ & $3.4 \pm 0.9$ & 15 \\
\hline II- $10,5000 \mathrm{ng}$ & -14 to -4 & $12.2 \pm 0.4$ & $5 / 5$ & $4.2 \pm 1.1$ & 60 \\
\hline IIL-4, $5 \mathrm{ng}$ & -14 to -4 & $14.5 \pm 3.0$ & $10 / 10$ & $3.2 \pm 0.9$ & 20 \\
\hline $\mathrm{IL}-12,200 \mathrm{ng}$ & -14 to -4 & $12.6 \pm 0.9$ & $13 / 13$ & $3.0+0.8$ & 8 \\
\hline
\end{tabular}

The day of immunization with homoginized mouse spinal cord and CFA is designated as day 0 .

2 IFN- $\gamma, 2000$ U/Day.

3 The significance of differences between groups with respect to EAE incidence were determined by Chi2 test: None vs TGF- $\beta$ : $p=0.05 ;$ None vs IL-4: $p<0.05$.

4 Differences in the max. EAE disease scores between groups were determined by Student's t test: None vs TGF- $\beta$ : $p=0.02 ;$ None us TGF $\beta$ + IL-4: $p<0.05 ;$ None vs IL-4: $p=0.05 ;$ None ws IL $-4+\operatorname{IFN}-\gamma$. $p=0.055$. None of the other comparisons showed statistically significant differences.

The following experiments were undertaken to evaluate whether $\Lambda_{-}-4$ and TGF $\beta_{2}$ administered prior to immunization with MHSC could also alter the susceptibility of mice to the induction of EAE The administration of TGF- $\beta_{2}$ prior to immunization $(-14$ to -2$)$ lead to a decrease in incidence and severity of EAE induction (Expt. 1, Table 3), as did prolonged pretreatment with $\mathrm{M}-4$ (from day -56 to day -2 ) at $5 \mathrm{ng} / \mathrm{day}$, while a shorter pretreatment period with $\mathrm{L}-4$ (from day -14 to -2) did not (Expts. 1 and 2, Table 3). To determine whether $\mathrm{LL}-4$ and TGF- $\beta$ had additive effects, we pretreated an additional group of mice with both these cytokines, from day -14 to day 2. As shown in Table 1 (Expt. 1), the decrease in severity obtained with both IL-4 and TGF- $\beta$ was comparable to the effect of TGF- $\beta$ alone when administered during the same interval. In view of the known antagonistic effects of $I I-4$ and IFN-g on Th1 and Th2 cell development, both in

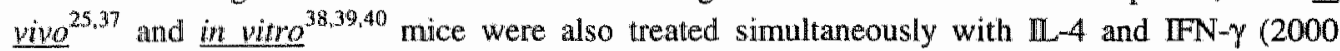
U/day), from day -56 to -2 . Such mice failed to show any protective effect from the pretreatment with IL-4 and were as sensitive as untreated control mice to the induction of EAE. 
These results raised the possibility that prolonged pretreatment with $\mathbb{L}-4$ or a relatively short pretreatment with TGF- $\beta$ might have had an immuno-regulatory effect prior to presentution of autoantigen in CFA. The effect of additional cytokines in this respect was also examined. In Expt. 2 (Table 3) mice were pretreated with $\mathbb{L}-4, \mathbb{L}-10$, or $\mathbb{L}-12$ on days -14 to -4 prior to induction of EAE. $\mathbb{L}-10$ caused a slight increase in mortality, but the effect was not statistically significant. In the groups of mice receiving IL-4 or IL-12 in this experiment, half of the mice in each group were injected with soluble PLP ( $1 \mathrm{mg}$ ) in the front footpads on day -14 (at the start of cytokine treatment).

It was reasoned that such a low dose would possibly sensitize or activate some $\mathrm{T}$ cells in the draining lymph nodes which would lead to a better subsequent response to immunization. However, there was no discernable effect of this additional PLP' injection. Therefore, in Table 3 the results obtained with and without PLP were combined. Cytokine treatment did not influence the severity or incidence of the subsequent EAE induction.

\section{Effect of cytokines administered during EAE induction}

As previously reported ${ }^{31}$ treatment with TGF- $\beta_{1}$ or TGF- $\beta_{2}$ on days 5-9 after immunization with MSCH in CFA (+ pertussigen) significantly inhibits the development of disease. It can be scen in Fig. $\|$ that as little as $100 \mathrm{ng}$ TGF- $\beta_{2}$ per day caused a significant reduction in the severity of acute EAE, while $1 \mathrm{mg} /$ day, even when injected only on days $5-7$, significantly reduced both incidence and severity. In contrast, TGF $\beta$ ( $1 \mathrm{mg} / \mathrm{day})$ on days $0-4$ has no significant protective effect ${ }^{31}$.

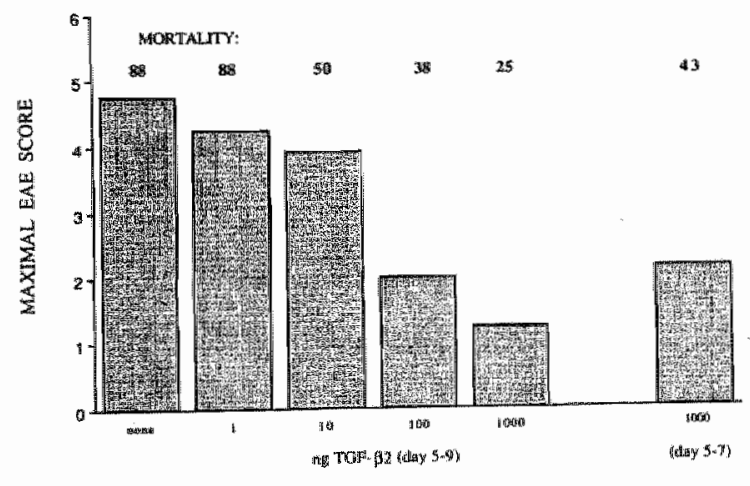

Figure 1: Dose response curve of the effect of TGF $\beta_{2}$ on the severity and incidence of EAE in SIL mice. The maximal EAE score was significantly lower than in controls in mice injected with $100 \mathrm{ng}$ ( $\mathrm{p}<0.01$ ) or $1000 \mathrm{ng}$ $(p=0.001)$ an days 5.9 , and in mice injected with $1000 \mathrm{ng} / \mathrm{day}$ on days $5-7(\mathrm{p}<0.02)(\mathrm{n}=8)$.

The effect of IL-4 injected after immunization with MSCH in CFA (+ pertussigen) was also examined. In contrast to TGF- $\beta_{2}, \pi /-4$ was most protective when given early during acute EAE induction. The results in Table 4 (Expt. 1) show that treatment with IL-4 on days 0-4 after immunization caused a reduction in the $\mathrm{EAE}$ incidence and severity, as well as in the mortality. 
Table 4

Protection against EAE by TGF-B2 and NL-4

\begin{tabular}{|c|c|c|c|c|c|}
\hline $\begin{array}{l}\text { Treatment } \\
\text { (ng/day) }\end{array}$ & (Days) & $\begin{array}{c}\text { First Day of } \\
\text { Symptoms }+ \text { SD }\end{array}$ & $\begin{array}{l}\text { Disease } \\
\text { Incidence }\end{array}$ & $\begin{array}{c}\text { Max. Disease } \\
\text { Score + SD }\end{array}$ & $\begin{array}{c}\% \\
\text { Mortality }\end{array}$ \\
\hline \multicolumn{6}{|l|}{ experiment 1} \\
\hline None & & $11.5 \pm 1.5$ & $15 / 16 \mathrm{a}$ & $4.2 \pm 1.6 \mathrm{bc}$ & $75 \mathrm{~d}$ \\
\hline II-4 (5) & $(0-4)$ & 13 & $1 / 5 \mathrm{a}$ & $0.40 \pm 0.80 \mathrm{~b}$ & $0 \mathrm{~d}$ \\
\hline IL-4 (5) & $(5-9)$ & $16.0 \pm 1.8$ & $4 / 5$ & $1.5 \pm 0.90 c$ & 0 \\
\hline \multicolumn{6}{|l|}{ experiment 2} \\
\hline None & & $12.7 \pm 1.1$ & $7 / 7$ & $2.6 \pm 1.1 \mathrm{e}$ & $14 \mathrm{f}$ \\
\hline$\Pi L-4(5)$ & $(0-4)$ & $13.3 \pm 1.5$ & $3 / 5$ & $1.3 \pm 1.2$ & 0 \\
\hline $\mathbb{I L}-4(5)$ & $(0-12)$ & $12.7 \pm 0.6$ & $3 / 5$ & $2.4 \pm 2.5$ & 0 \\
\hline $\mathbb{N L}-10(1000)$ & $(0-4)$ & $12.3 \pm 1.0$ & $6 / 6$ & $3.0 \pm 1.7$ & 50 \\
\hline ILL- $12(50)$ & $(0-4)$ & $12.3 \pm 1.0$ & $6 / 6$ & $4.5 \pm 1.2 \mathrm{e}$ & $83 \mathrm{f}$ \\
\hline
\end{tabular}

The significance of differences between groups with respect to EAE incidence or mortality were determined by Chi 2 test: a) $p<0.005$; d) $\mathrm{p}<0.011$; 0 p $\mathrm{p}<0.005$.

Differences in the max. EAE disease scores between the similarly footnoted values were determined by Student"s $t$ test: b) $p<0.0001 ; c) p=0.002 ;$ e) $p=0.01$.

When injected on days 5-9, IL-4 also reduced the severity of EAE, but not the disease incidence. The control group in Expt. 2 (Table 4) had a lower maximal score than in Expt. 1. Consequently the protective effect of IL-4 given on days 0-4 was not as great as in Expt. 1. In addition, when injected on days $0-12, \mathbb{L}-4$ had no effect at all, suggesting that treatment with $\mathbb{L}-4$ during the later part of the induction period of EAE counteracted the beneficial effects of $\mathrm{IL}-4$ given during the earlier part. IL-10 falled to influence acute EAE when given on days $0-4$ at $1 \mathrm{mg}$ per day. In complete contrast with $\mathrm{LL}-4$ and TGF- $\beta, \mathrm{LL}-12$ injected on days $0-4$ after induction of EAE significantly augmented EAE severity and mortality.

\section{Inability of SEB to induce relapses in PLP-ECDL-SP tolerized miice}

In previous studies, it has been shown that SEB induces relapses of EAE in PL/J but not in SJL/J mice that have recovered from acute $\mathrm{EAE}^{41.42}$. 
Tahle 5

Lack of SEB-induced $E A E$ relapses in tolerant S.JL MICE

\begin{tabular}{ccc}
\hline Parameter & Control Mice & Tolerant Mice \\
\hline
\end{tabular}

Treatment on:

Day -7

ECDI-Spleen cells iv

PLP-ECDI-Spleen cells iv

Day 0

$\mathrm{MSCH}+\mathrm{CFA}$

$\mathrm{MSCH}+\mathrm{CFA}$

Max. EAE Score ${ }^{\text {on: }}$

Day 11-17

Day Before SEB* iv

2-3 Days After SEB* iv

Incidence of:

SEB-Induced Relapse
$2.79 \pm 0.58 \mathrm{a}$

$0.29 \pm 0.43 b$

$0.93 \pm 0.73 b$
$0.20 \pm 0.45 \mathfrak{c}$

$0.40 \pm 0.55$

$0 \mathrm{c}$

$1 / 5(20 \%)$

(6) Max. EAE disease scores in the similarly footnoted values were compared by Student's $t$ test: $a)$ p<0,0004; b) P<0.01; c) NS.

* $50 \mathrm{mmg}$ of $\mathrm{S}$. enterotoxin iv severall weeks after recovery from the first EAE episode.

We re-examined whether, in spite of the absence of $V \beta 8^{*} \mathrm{~T}$ cells, recovered SIL mice would exhibit relapses after injection of SEB, and if so, whether mice that had been protected from acute EAE through tolerance would nevertheless exhibit relapses when given SEB several weeks after immunization with MSCH in CFA. As seen in Table 5, there was a mild but significant increase in EAE severity within 2-3 days after injection of SEB in approximately $50 \%$ of control mice, while there was no significant increase in the tolerant mice.

\section{Discussion}

The results of the present study confirm the work by others (reviewed $\mathrm{in}^{43}$ ) that the iv injection of PLP coupled to spleen cells causes a profound resistance to the subsequent induction of EAE with PLP or even with whole MSCH in CFA in SIL mice.

Various mechanisms exist by which iv injection of antigen (peptide) coupled spleen cells may induce resistance to EAE induction. Firstly, creation of a peripheral pool of neuroantigen, that prevented specific $T$ cells from entering the CNS, was not considered critical by Miller et al, ${ }^{43}$ because the same amount of antigen injected in unbound form did not cause tolerance. However, larger amounts of unbound peptide do have protective effects against $\mathrm{EAE}^{44,45}$.

Secondly, induction of immunoregulatory cells with iv injected antigen-coupled spleen cells, shown in the present study in mice and previously in rats ${ }^{30}$, is certainly not the only mechanism 
by which these spleen cells protect against EAE. Protection against passively transferred EAE can be obtained by injection of MBP-coupled spleen cells together with the EAE-inducing MBPspecific effector $\mathrm{T}$ cells ${ }^{1013}$; in such mice there would have been insufficient time for the development of immunoregulatory cells. In the present studies, the resistance to $\mathrm{EAE}$ induced by PLPECDI-SP occurred just as readily in $15-17$ mos old as in $2-4$ mos old mice. If immunoregulatory $T$ cells were the major mechanism by which the animalls develop resistance to $\mathbb{E A E}_{\mathrm{x}}$ an induction of tolerance might not have been expected in the older mice. Induction of antigen-specific immunoregulatory $T$ cells is reported to be deficient in ageing mice ${ }^{46}$, although age-related effects on suppression and tolerance may differ depending on the mouse strain and the nature of the antigen used ${ }^{47,48}$.

Treatment with anti-CD8 antibody decreases the resistance to reinduction of EAE in B 10.PL mice recovering from an acute $\mathrm{EAE}$ episode ${ }^{49}$ and $\mathrm{CD} 8^{-/-}$mice show more relapses of EAE than do normal mice ${ }^{50}$. Ag specific $T$ cells able to transfer resistance to $E A E$ induction also have been detected after recovery from EAE and after oral tolerance induction ${ }^{23}$. The mechanism by which such $T$ cells down regulate the encephalitogenic properties of other myelin-specific $T$ cells needs further study. Although not yet demonstrated for iv induced tolerance, production of nonspecific immunosuppressive factors, such as TGF- $\beta$, has been implicated ${ }^{24,51,52}$.

Thirdly, the reversal of the tolerance that we have observed after injection of $\mathbb{L}-2$ suggests that anergy of PLP-specific T cells plays an important role in the resistance to EAE induction. Antigen coupled ECDI-treated cells were shown by Jenkins and Schwartz ${ }^{53}$ to induce antigen-specific unresponsiveness of cloned $\mathrm{T}$ cellls. The tolerant cells, however, responded even better to a subsequent exposure to IL-2 than did control cells. Other in vitro studies on the induction of anergy of $T$ cells (reviewed in $^{54}$ ) have shown the importance of inhibition of $\mathrm{CL}-2$ synthesis in this phenomenon as well as the rolle of $T$ cell costimulation in the induction of $1 L-2$ synthesis ${ }^{55.56}$. In the present in vivo studies, it was found that repeated injections of $\mathrm{IL}-2$ prevent tolerance induction only when given a few days after antigen-coupled spleen cells, but not when started on the same day. This finding is in agreement with results from in vitro studies, where addition of $\amalg$ 2 prior to, or at the same time as antigen in tolerogenic form, creates a greater degree of unresponsiveness to antigen ${ }^{36,45}$ rather than the reversal of anergy. Prolonged exposure to IL-2 following induction of anergy is thought to reverse anergy by causing proliferation, resulting in dilution and loss of a negative intracellular regulating factor ${ }^{18}$.

The mechanism by which SEB induces mild exacerbations of EAE is not entirely clear, but is probably related to the presence of expanded neuroantigen-specific $\mathrm{T}$ cell clones bearing $\mathrm{VB} 17 \mathrm{a}$ in the immunized SJLJ mice ${ }^{57}$. In the present studies, the injection of SEB several weeks after immunization induced a significant increase in the EAE severity in control, but not in tolerized SJL mice. These findings suggest that there was no expansion of the PLP-responsive $T$ cell population in the tolerized mice, as would be expected if the cells had been rendered anergic.

It is possible that the induction of anergic antigen-specific and immunoregulatory $\mathrm{T}$ cells are interdependent during the development of resistance to EAE induction. Sensitization of TCRspecific immunoregulatory $T$ cells might be induced more readily by partially activated anergic $T$ cells than either by resting or highly proliferating responding $\mathrm{T}$ cells $\mathrm{s}^{5 \%}$. The induction of both 
$\mathrm{CD}^{*}$ and $\mathrm{CD} 8^{*}$ suppressor/cytotoxic cells with clonotypic $\mathrm{V} \alpha^{59}$ or $\mathrm{V} \beta^{60.61}$ specificity against encephalitogenic $\mathrm{CD}^{+} \mathrm{T}$ cells has been shown in rodents.

Lastly, changes in the cytokine profile of the response to antigen may be an important aspect of the tolerance induced by antigen-coupled spleen cells. In fact, an important aspect of anergy induced by stimulation of $T$ cells in the absence of costimulation is that the formation of Th 1 cells, responsible for delayed hypersensitivity, $\mathbb{L}-2$, IFN- $\gamma$ and TNF production is much more inhibited than that of Th2 cells, producing $\mathbb{I L}-4, \mathbb{L}-5$ and $\Pi-10^{26}$. This has been shown in vive after injection of antigen-coupled spleen cells ${ }^{62,63}$ as well as in virro after stimulation with immobillized anti-CD $3^{26,64}$. However, cloned $\mathrm{Th} 2$ cells may show no decrease in their proliferative responses after tolerance induction by antigen-coupled spleen cells in vitro, but their helper activity for antibody responses is decreased ${ }^{27}$.

It has been shown previously that TNF production, a typical Thl cell product ${ }^{25}$, is correlated with the ability of cell lines to transfer $\mathbb{E A E}^{65,66}$. Moreover, anti-TNF protects against $\mathbb{E A E}$ in acute, relapsing ${ }^{31}$ and adoptive $\mathrm{EAE}^{67,68}$. Therefore, in the present study we have examined the effect of cytokines known to influence the Th1 to Th2 cell ratio in the immune response. The cytokines were injected either before or during induction of EAE. Pretreatment with L-4 reduced the sensitivity to EAE induction only when it was injected over a period of 8 weeks; a shorter pretreatment interval of 2 weeks was ineffective. Simultaneous treatment with IFN- $\gamma$ abrogated the effect of long term $\mathbb{L}-4$. The effect of prolonged treatment with $\mathbb{L}-4$ may be similar to that obserwed in NOD mice, where IL-4 is known to inhibit the natural development of diabetes ${ }^{69}$, and anti-IFN- $\gamma$ has the same effect ${ }^{70}$.

A short pretreatment with $I L-4$ was not effective. In contrast, as few as five daily injections of $I L$ 4 immediately after immunization with PLP + CFA significantly protected against EAE development. This effect appeared greater when $\mathrm{L}-4$ was administered during the first five days than during the second five days after immunization. No effect was found when a longer, 12-day treatment interval with IL-4 after immunization was used suggesting that IL-4 perhaps had multiple counteracting effects on the course of EAE. In contrast to IL -4 , five daily injections of IL-12 after inmunization with PLP significantly increased the severity of EAE. Preimmunization injections of $\Pi_{-}-12$ had no significant effect. Thus, in order to obtain an effect of short term treatment with $\mathbb{L}-4$ or $\mathbb{L}-12$, there had to be simultaneous activation of antigen-specific $T$ cells by immumization with PLP in CFA. The protective effect of $\mathrm{L}-4$ and the augmenting effect of $\mathrm{IL}_{-}$ 12, given early during the induction of EAE, agree with the expectation that the promotion of Th2 development in this response would protect, while that of Th 1 development would augment disease. IL-12 potentiates the development of Th1 cells during the immune response $\mathrm{e}^{71,72,73}$. Thus, the established effects of IL-4 and IL-12 in promoting Th2 and Th1 cell development, respectively, during the response to microbial and parasitic antigens ${ }^{74,29}$ also appears to apply to the immune response to encephalitogenic auto-antigens.

IL-10 and TGF- $\beta$ have each been shown to inhibit antigen presentation and macrophage function ${ }^{75,76,77}$. Both inhibit TNF- $\alpha$ production, and IL-10 suppresses the antigen presenting celldependent induction of IFN- $\gamma$ production in Thl cells ${ }^{78}$. Augmented synthesis of $11-10$ in spinal cord is associated with the recovery phase from EAE in SJL mice ${ }^{79}$. IL-10 specifically down regulates. Th1 cell activation ${ }^{78,80}$, apparently by inhibiting $B 7$ upregulation and $L-12$ production 
in macrophages ${ }^{81,82 .}$ and it synergizes with $\mathbb{L}-4$ to inhibit delayed hypersensitivity in vivo ${ }^{83}$. Rott et al. ${ }^{84}$ showed that II-10, given on days, 0,3 and 6 after immunization, protects against induction of EAE in rats. It is surprising that IL-10 had no protective effect in the present studies, neither when injected before nor during induction of EAE. The dose or timing of $\mathbb{L}-10$ may not have been optimal to obtain an effect on acute EAE. Further studies are underway to elucidate this aspect. It should be noted, however, that accelerating effects of IL-10 on immune-mediated destruction rather than protection of $\beta$ cells in NOD mice have been obtained ${ }^{85}$.

The effect of TGF- $\beta$ on EAE is two-fold: 1) as also shown previously ${ }^{31}$, TGF- $\beta$ provides excellent protection against EAE development when administered during the second 5-day interval after immunization, but is completely ineffective when given earlier or later; 2) treatment with TGF $\beta$ prior to immunization with spinal cord significantly reduces the susceptibility to EAE induction. In previous studies on the protective effect of TGF- $\beta$ against EAE, we showed that it did not interfere with the development of PLP- or MBP-sensitized T cells, but that it did prevent their entry into the CNS. We postulated that its effect during that step of the sensitization process was related to an influence on the interaction between effector cells and CNS endothelia. TGF- $\beta$ has been implicated as one of the mediators of immune deviation ${ }^{86}$, and it affects $\mathrm{T}$ cell subset distribution in the immune response ${ }^{39,87}$. It clearly has a physiological role in preventing inflammatory processes and autoaggression, as evidenced by the early death through excessive inflammatory responses in TGF- $\beta 1^{-1-}$ (knockout) mice ${ }^{88,89}$. TGF- $\beta$ might also augment the resistance to EAE induction by increasing $\mathrm{CD}^{+} \mathrm{T}$ cell activity. In vitro differentiation and growth supporting effects of TGF- $\beta$ on $C D 8^{*} T$ cells from the thymus ${ }^{90.91}$ and peripheral lymphoid tissue $^{92,93,94}$ have been reported. Thus, the schedule-dependent nature of TGF- $\beta$ mediated protection against EAE may be related to a combination of some of the cytokine's multiple sites of action.

In conclusion, it appears that both the iv pretreatment with non co-stimulating forms of autoantigen and changes in the cytokine milieu may enhance the resistance of mice to the induction of experimental autoimmune disease. The applicability to human disease of iv injection of autoantigen coupled to resting autologous $\mathrm{B}$ cells remains to be determined. Oral administration of antigen appears to induce tolerance by very similar mechanisms as the ones discussed above for iv induced tolerance ${ }^{24,95,96}$. However, the absence of a clearcut dose responsiveness and the relative lack of predictability of oral tolerance induction may complicate its clinical use. The present results also suggest that prolonged administration of cytokines alone, particularly of IL-4 and/or TOF- $\beta$, may be useful in the treatment of multiple sclerosis.

\section{Acknowledgements}

We are greatly indebted to Dr. Sydney Smith (Schering- Plough Research Inst, Kenilworth, NJ) for helpful discussions and generous donations of $\mathrm{IL}-4$ and $\mathrm{IL}-10$, to Dr. Maurice K. Gately (Hoffmann-La Roche Inc., Nutley, NJ) for useful advice and a gift of $\mathbb{L}-12$, and to Dr. Joseph A. Carlino (Celtrix Pharmaceuticals Inc., Santa Clara, $\mathrm{CA}$ ) for constructive criticisms and a gift of TGF- $\beta_{2}$. The expert assistance of Ms. Betty Tomasello in the preparation of this manuscript is gratefully acknowledged. 


\section{References}

3 Kappler NW, Roehm N and Marrack P - T cell tolerance by clonal elimination in the thymus. Cell, 1987; 49:273. 280.

2 Kisielow P, Bluthmann H. Staerz UD, Steinmetz M and von Boehmer H - Tolerance in T-cell-receptor transgenic mice inwolves delletion of nonmature $\mathrm{CD}^{+} 8^{+}$thymocyles. Nature, $1988 ; 333.742$ 746.

I Sun D, Ben-Nun A and Wekerle H - Regulatory circuits in autoimmunity: recruitment of counter-regulatory CD: ${ }^{*}$ $T$ cells by encephalitogenic CD4 $4^{+} \mathrm{T}$ line cells. Eur ${ }^{\prime}$ Immunol, 1988; 18:1993-1999.

4 Ramsdell $\mathrm{F}$ and Fowlkes $\mathrm{BJ}$ - Clonal deletion versus clonal anergy: The role of the thymus in inducing self tolerance. Science, 1990;248:1392-1348.

5 Tuohy VK Lu $Z$ Sobel RA Laursen RA and Lees MB - A synthetic peptide from myelin proteollipid protein induces experimental allergic encephalomyelitis. J Inmunol, 1988; 141: 1126-1130.

6. Zamvil S, Nelson P. Trotter J, Mitchell D, Knobler R. Fritz R and Steimman L - T-cell clones specific for myelin basic protein induce chronic relapsing paralysis and denyelination. Nature (Lond), 1985; 317.355-358.

T Brown A, McFarlin DE and Raine CS - Chronologic neuropathology of relapsing experimental allergic encephallomyelitis in the mouse. Lab Invest, $1982 ; 46: 171-185$.

8 Sobel RA, Blanchette BW, Bhan AK and Colvin RB - The imumunopathology of experimental allergic encephalomyelitis. I. Quantitative analysis of inflammatory cells in situ. J Immunol, 1984; 132:2393-2401.

9 Traugou $\mathrm{U}$ - Detailed analysis of early immunopathologic events during lesion formation in acute experimental autoimunue encephalomyelitis. Cell Immunol, 1989; 119:114-129.

10 Kenredy MK, Tan LJ, Dal Canto MC and Miller SD - Regulation of the effector stages of experimental autoimmune encephalomyelitis via neuroantigen-specific tolerance induction. J Immunol, 1990a; 145:1 17-126.

$"$ Kennedy MK, Tan LJ, Dal Canto MC, Tuohy VK, Lu Z, Trotter JL and Miller, SD - Inhibition of murine relapsing experimental autoimmune encephalomyelitis by immune tolerance to proteolipid protein and its encephalitogenic peptides. J Immunol, 1990b; 144:909-915.

12. Tan $\mathrm{LJ}$, Kennedy MK, Dal Canto MC and Miller, SD - Successful treatment of paralytic relapses in adoptive experimental autoimmune encephalomyelitis via neuroantigen-specific: tolerance. J Immunol, 1991; 147:1797. 1802.

13 Tan $\mathrm{LJ}$, Kennedy MK and Miller SD - Regulation of the effector stages of experimental autoimmune encephalonnyelitis via neuroantigen- specific colerance induction. Il. Fine specificity of effector $T$ cell inhibition. I Imumunol, 1992; 148:2748-2755.

14 Su X-M and Sriram S - Treatment of chronic relapsing experimental allergic encephalomyelitis with the intravenous administration of splenocytes coupled to encephalitogenic peptide 91-103 of myelin basic protein J Neuroimumunol, 1991; 34:181.190.

is Kennedy MK, Dal Canto $\mathrm{C}$, Trotter $\mathrm{IL}$ and Miller SO - Specific immune regulation of chronic-relapsing experimental alliergic encephalomyelitis in mice. I Immunol, 1988; 141:2986-2993.

16 Miller SD. Tan LJ. Kennedy MK and Dal Canto MC - Specific immunoregulation of the induction and effector stages of relapsing EAE via neuroantigen-specific tolerance induction. Ann NY Acad Sci, 1991; 636:79.94.

"7 Schwartz RH - A cell culture model for T lymphocyte clonal anergy. Science, 1990; 248:1349-1356.

18 Beverly $B_{*}$ Kang SM, Lenardo MJ and Schwartz RH - Reversal of in vitro T cell clonal anergy by IL-2 stimulation. Int Immunol, 1992; 4:661-671.

19 Swierkosz JE and Swanborg RH - Suppressor cell control of unresponsiveness to experimental aflergic encephalomyelitis. I Immunol, 1975; 115:631-633.

20 McDonald AH and Swanborg RH - Antigen-specific inhibition of immune interferon production by stppressor cells of autoimmune encephalomyelitis. J Immunol, 1988; 140:1132-1138.

21 Sun D and Klinkert WEF - Functional heterogeneity among CD4 ${ }^{+}$encephalitogenic "T cells in recruitment of CD8* T cells in experimental autoimmune encephalomyelitis. J Immunol, 1989; 143:2867.2872. 
22 Higgins PJ and Weiner HL - Suppression of experimental autoimmune encephallomyelitis by oral administration of myelin basic protein and its fragments. I Immunol, 198:; 140:440-445.

23 Lider $O$, Santos LMB, Lee CSY, Higgins PJ and Weiner HL - Suppression of experimental autoimmune encephatomyelitis by orall administration of myelin basic protein. II. Suppression of disease and in vitro immune. responses is mediated by antigen-specific CD8 ${ }^{\top} T$ lymphocytes. J Immunol, 1989; 142:748-752.

2 Miller A, Lider O, Roberts AB, Sporn MB and Weiner HL - Suppressor T cells generated by oral tolerization to myelin basic protein suppress both in vitro and in vivo immune responses by the release of transforming growth factor b after antigen-specific triggering. Proc Natl Acad Sci USA, 1992a; 89:421-425.

25 Coffman RL, Varkila K, Scott $\mathrm{P}$ and Chatelaim $\mathrm{R}$ - Role of cytokines in the differentiation of CD4 ${ }^{*}$ T-cell subsets in vivo. Immunol Rev, 1991; 123:180-207.

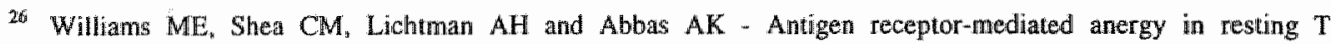
lymphocytes and T cell clones. Correlation with lymphokine secretion patterns. J Immunol, 1992; 149:1921-1926.

27 Gilbert KM, Hoang KD and Weigle WO - Th1 and Th2 clones differ in their response to a tolerogenic signal. J Immunol, 1990; 144:2063-2071.

28. Heinzel FP, Sadick MD, Holaday BJ, Coffman RL and Locksley RM - Reciprocal expression of interferon ganma or ILA during the resolution or progression of murine leishmaniasis. Evidence for expansion of distinct helper T' cell subsets. J Exp Med, 1989; 169:59-72.

29 Finkelman FD, Madden KB, Cheever AW, Katona IM, Morris SC, Gately MK, Hubbard BR, Gause WC and Urban JF Jr - Effects of Interle ukin 12 on immune responses and host protection in mice infected with intestinal nematode parasites. J Exp Med "1994; 179:1563-1572.

30 Strejan GH and St Louis J - Suppression of experimental allergic encephalomyelitis by MBP-coupled lymphoid cells and by MBP-liposomes: A comparison. Cell Immunoll, 1990; 127:284-298.

31 Santambrogio L, Hochwald GM, Saxena B, Leu CH, Martz JE, Carlino JA, Ruddle NH, Palladino MA, Gold LI and Thorbecke GI - Studies on the mechanisms by which TGF- $\beta$ protects against allergic encephalomyelitis: antagonism between endogenously produced TGF- $\beta$ and TNF. J Immunol, 1993; 151:1116-1127.

32 Munoz JJ, Bernard CCA and Mackay IR - Elicitation of Experimental allergic encephalomyelitis (EAE) in mice with the aid of pertussigen. Cell Immunol, 1984; 83:92 100.

31. Miller SD, Wetzig RP and Claman HN - The induction of cell- mediated immunity and tolerance with protein antigens coupled to syngeneic lymphoid cells. I Exp Med, 1979; 149:758-773.

${ }^{34}$ Coffey RJ Jr, Kost LJ, Lyons RM, Moses HL and LaRusso NF - Hepatic processing of transforming growth factor- $\beta$ in the rat: uptake, metabolism and biliary excretion. I Clin Invest, 1987; 80:750-755.

35 Donohue JH and Rosenberg $\$ \mathrm{~A}$ - The fate of IL-2 after in yivo administration. J Immunol, 1983; 130:2203-2208.

36 Otten $G$, Wilde DB, Prystowsky MB, Olshan IS, Rabin H, Henderson LE, and Fitch FW - Cloned helper $T$ lymphocytes exposed to interleukin- 2 become unresponsive to antigen and concanavalin $A$ but not to calcium ionopliore and phorbol ester. Eur I Immunol, 1986; 16:217-225.

37 Locksley RM, Heinzel FP, Holaday BJ, Mutha SS, Reiner SL and Sadick. MD - Induction of Th1 and Th2 CD4 ${ }^{+}$ subsets during murine Leishmania major infection. Res Immunol, 1991; 142:28-32.

38 Gajowski TF, Joyce J and Fitch FW - Anti-proliferatiwe effect of IFNngamma in immune regulation. III Differential selection of Th1 and Th2 murine helper $\mathrm{T}^{*}$ lymphocyte clones using recombinant IL-2 and recombinant IFN-gamma. J Immunol, 1989; 143:15-22.

39. Swain SL, Huston G, Tonkonogy S and Weinberg A - Transforming growth factor $\beta$ and IL -4 cause helper $T$ cell precursors to develop into distinct effector helper cells that differ in lymphokine secretion pattern and cell surface phenotype. I Immunol, 1991; 147:2991-3000.

40 Maggi E. Parronchi P. Manetti R, Simonelli C, Piccinni M-P, Santoni Rugiu F, De Carli M, Ricci M and Romagnani 5 - Reciprocal uegulatory effects of IFN-gamma and IL-4 on the in vitro development of human Th1 and Th2 clones. J Imununol. 1992; 148:2142-2147.

¿1 Schiffenbauer J, Johnson HM, Butfiloski EJ, Wegrzyn L and Soos JM - Staphyloccocal enterotoxins can reactivate experimental allergic encephalomyelitis. Proc Natl Acad Sci USA, 1993; 90:8543-8546. 
42 Brocke S, Gaur A, Piercy C, Gautam A, Gijbels K, Fathman CG and Steinman L - Induction of relapsing paralysis in experimental autoimmune encephatomyelitis by bacterial superantigen. Nature, 1993; 365;642-644.

43 Miller SD, Tan LJ, Pope L. McRae BL and Karpus WJ - Antigen-specific tolerance as a therapy for experimental allergic encephalomyelitis. Int Rev lmmunol, 1992b;9:203-222.

44 Gaur A, Wiers B, Liu A, Rothbard J and Fathman CGi - Amelioration of autoinmune encephalomyelitis by myelin basic protein synthetic peptide-induced anergy. Science, 1992; 258:1491-1493.

45 Critchfield JM, Racke MK, Zuniga-Pflucker JC, Cannella B, Raine CS, Goverman J and Lenardo MJ - T cell deletion in high antigen dose therapy of autoimmnune encephatonyelitis. Science, 1994; 263:1139-1143.

4t Gottesman SRS, Edington JM and Thorbecke GJ - Proliferative and cytotoxic immune functions in aging mice. V. Effects of suppressor cell proliferations from aged and young mice. I Immunol, 1988; 140:1783-1790.

47 Thonan ML and Weigle WO - Deficiency in suppressor T cell activity in aged animals: reconstitution of this: activity by interleukin 2. J Exp Med, 1983; 157:2184-2189.

${ }^{48}$ Habicht GS - Acquired immunological tolerance in aged mice. II. The cellullar basis of the loss of tolerance sensitivity. Mech Aging Dev, 1985; 30:23-36.

49 Jiang $\mathrm{H}$, Zhang S-L and Pernis $\mathrm{B}-$ Role of $C D 8^{+} \mathrm{T}$ cells in murine experimuental allergic encephalonyelitis. Science, $1992 ; 256: 1213-1215$.

50 Koh D-R, Fung-Leung W-P, Ho A, Gray D, Acha-Orbea and H Mak T-W - Less mortality but more relapses in experimental allergic encephalo- myelitis in $\mathrm{CD}^{-/ 4}$ mice. Science, $1992 ; 256: 1210-1213$.

st Karpus WJ and Swanborg RH - CD4 $4^{*}$ suppressor cells inhibit the function of effector cells of experimental autoimmune encephalornyelitis through a mechanism involving transformating growth factor- $\beta 1$. I Immunol, $1991 ; 146: 1163-1168$.

52 Chen YC, Kuchroo VK, Inobe J-I, Hafler DA and Weiner HL - Regulalory T cell clones induced by oral tolerance: Suppression of autoimmune encephalomyelitis. Science, 1994; 265:1237-1240.

53 Jenkins MK and Schwartz RH - Antigen presentation by chemically modified splenocytes ind uces anigen-specific T cell unresponsiveness in vitro and in wivo. J Exp Med, 1987; 165:302-319.

54 Mondino A and Jenkins MK - Surface proteins involved in T cell costimulation. J Leuk Biol, 1994; 55:805-815.

55 Jenkins $\mathrm{MK}_{*}$ Taylor PS, Norton SD and Urdahl KB - CD28 deliwers costimulatory signal involved in antigenspecific IL-2 production by lwuman T cells. J Immunol, 1991; 147:2461-2466.

56 Liu $Y$ and Linsley PS - Costimulation of T-cell growth. Current opinion in Immunol, 1992; 4:265-270.

57 Yamamura $Y$, Kondo T, Sakanaka $S$, Kozovska $M$, Geng T-C, Takahashi $K$ and Tabira $T$ - Anallysis of $T$ cell antigen receptors of myelin basic protein specific $T$ cells in SNLJ mice demonstrates an a chain CDR3 motif associated with encephallitogenic T cells. Int Immunol, 1994; 6:947-954.

98. Pernis B - Do anergic T cells induce suppressor T lymphocyles through idiotypic interactions? Int Rev Imnunol, $1993 ; 10: 327-335$.

39 Karpus WJ, Gould KE and Swanborg RH - CD4 suppressor cells of autoimmune encephalonyelitis respond to T cell receptor-associated determinants on effector cells by interleukin-4 secretion. Eur $J$ Immunol $1992 ; 22: 1757$ 1763.

60. Qin $Y$, Sun D and Wekerle H - Immune regulation in self tolerance: functional elimination of al self-reactive, counterregulatory $\mathrm{CDB}^{*} \mathrm{~T}$ lymphocyte circuit by neonatal transfer of encephalitogenic $\mathrm{CD}^{*} \mathrm{~T}$ cell lines. Eur $I$ Immunol, 1992;22:1193-1198.

6) Kumar $\mathrm{V}$ and Sercarz $\mathrm{EE}$ - The involvement of $\mathrm{T}$ cell receptor peptide- specific regulatory $\mathrm{CO} 4^{+} \mathrm{T}$ cells in recovery from antigen-induced autoimmune disease. J Exp Med, 1993; 178:909.916.

62 Peterson JD, Karpus WJ, Clatch RJ and Miller SD - Split tolerance of Th1 and Th2 cells in tolerance to Theiler's murine encephalonyelitis virus. Eur J Immunol، 1993; 23:46-55.

6.3 Karpus. WJ, Peterson JD and Miller SD - Anergy in kivo : down-regulation of antigen-specific CD4" "Thl but not Th2 cytokine responses. Int Immunol, 1994;6:721-730. 
Gajewski TF, Lancki DW, Stack R and Fich FW - Anergy of ThO helper $T$ lymphocytes induces downregulation of "Th1 characteristics and atransition to a Th2-like phenotype. J Exp Med, 1994; 179:481 491.

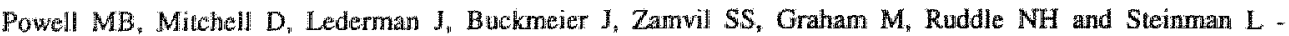
Lymphotoxin and tumor necrosis factor- $\alpha$ production by myelin basic protein-specific $T$ cell clones correlates with encephalomitogenicity. Int Immunol, 1990; 2:539-544.

Day MJ and Mason DW - Loss of encephalitogenicity of a myelin basie protein-specific T cell line is associated with a phenotypic change but not with alteration in production of interleukin-2, gamma-interferon or tumor necrosis factor. J Neuroimmunol, 1990:30:53-59.

67 Ruddle NH, Bergman CM, McGrath KM, Lingenheld EG, Grunnet ML, Padula SJ and Clark RB - An antibody to lymphotoxin and tumor necrosis factor prevents transfer of experimental allergic encephalomyelitis. J Exp Med, 1990: 172:1193-1200.

68 Selmaj $K$, Raine CS and Cross AH - Anti-tumor necrosis factor therapy abrogates autoimmune demyelination. Ann Neurol, 1991; 30:694-700.

${ }^{69}$ Rapopont MJ, Jaramillo A, Zipris D, Laxarus AH, Serreze DV, Leiter EH, Cyopick P, Danska IS and Delowitch TL - Interleukin 4 rewerses $T$ cell proliferative unresponsiveness and prevents the onset of diabetes in nonobese diabetic mice. I Exp Med, 1993; 178:87-99.

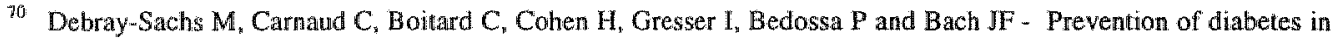
NOD mice treated with antibody to murine IFN-gamma. J Autoimmun, 1991; 4:237-248.

1 Gately M, Desai B, Wolizky A, Quinn P, Dwyer C, Podlaski F, Familletti P, Sinigaglia F, Chizonnite R, Gubler $U$ and Stern A - Regulation of human lymphocyte proliferation by a heterodimeric cytokine, IL-12 (cytotoxic lymphocyte maturation factor). J Immunol, 1991; 147:874-882.

12 Trinchieri G - Interleukin-12 and its role in the generation of Th1 cells. Immunol Tod, 1993; 14:335-338.

${ }^{73}$ Hsieh C.S, Macatonia SE, Tripp CS, Wolf SF, OGarra A and Murphy KM - Development of Th1 CD4 ${ }^{+} \mathrm{T}$ cells through IL-12 produced by Listeria-induced macrophages. Science, 1993; 260:547-549.

74 Scott P, Pearce E, Cheever AW. Coffman RL and Sher A - Role of cytokines and CD4 ${ }^{+}$T-cell subsets in the regulation of parasite immunity and dlisease. Immunol Rev, 1989; 112:161-182.

75 Hsieh $\mathrm{C}-\mathrm{S}$, Heimberger $\mathrm{AB}$, Gold JS, $\mathrm{O}^{\prime}$ Garra $\mathrm{A}$ and Murphy KM - Differential regulation of $\mathrm{T}$ helper phenotype devellopment by interleukin 4 and 10 in an $\alpha / b$ T-cell-receptor transgenic system. Proc Natl Acad Sci USA, 1992; 89:6065-6069.

76 Bogdan C, Vodovotz $Y$ and Nathan C - Macrophrage deactivation by interlleukin 10. J Exp Med, 1991; 174:15491555 .

7 Srimal $S$ and Nathan $C$ - Purification of macrophage deactivating factor. I Exp Med, 1990; 171:1347-1361.

74 Fiorentino DF, Zlotnilk $A$, Vieira $P$, Mosmann TR, Howard $M$, Moore KW and OGarra A - IL-10 acts on the antigen-presenting cell to inhibit cytokine production by Thl cells. J Immunol, 1991; 146:3444-3451.

79 Kennedy MK, Torrance DS, Picha KS and Mohler KM - Analysis of cytokine mRNA expression in the central nervous system of mice with experinental autoimmume encephalomyelitis reveals that IL-10 mRNA expression correlates with recovery. J Immunol, 1992; 149:2496-2505.

4her A, Fiorentino D, Caspar P, Pearce E and Mosmann T - Production of IL-10 by CD4 $4^{*}$ T lymphocytes correlaties with down-regulation of Thl cylokine synthesis in helminth infection. J Immunol, 1991; 147:27132716.

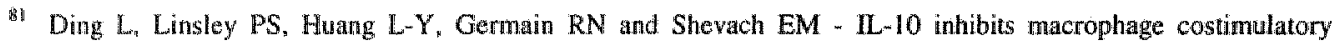
activity by selectively inhibiting the up-regulation of B7 expression. J Immunol, 1993; 151:1224-1234.

82 Tripp CS and Unanue ER - Interleukin 12 and tumor necrosis factor alpha are costimulators of interferon gamma production by natural killer cells in severe combined inmunodeficiency mice with listeriosis, and interleukin 10 is a physiologic antagonist. Proe Natl Acad Sci USA, 1993; 90:3725- 3729.

83 Powrie F, Menon S and Coffman R - Interleukin-4 and interleukin-10 synergize to inhibit cell-mediated immunity in wivo. Eur J Inmunol, 1993; 23:3043-3049. 
84 Rott $\mathrm{O}$, Fleischer $\mathrm{B}$ and Cash $\mathrm{E}$ - Interleukin 10 prevents experinnental allergic encephälomyelitis in rats. Eur I Inmunol. 1994; $24: 1434-1440$.

8 Wogensen L, Lee M-S and Sarvetnick N - Production of interleukin 10 by islet cells accelerates immume-mediated destruction of $\beta$ cells in nonobese diabetic mice. J Exp Med, 1994; 179:1379-1384.

26 Wilbanks GA and Streilein JW - Fluid from immune privileged sites endow macrophages with the capacity to induce antigen-specific immune deviation via a mechanism involving transforming growth factor-beta. Eur df Immunol, 1992; 22:1031-1036.

87 Weinberg AD, Whiman R, Swain SL, Morrison WJ, Wyrick G, Hoy C, Vandenbark AA and Offner $H$ Transforming growth factor $\beta$ enhances the in wivo effector function and memory phenotype of antigen-specific $T$ helper cells in experimental autoimmune encephalonyelitis. J Innnanol, 1992, 148:2109-2117.

Kulkarni $A B$, Huh $C-G$. Becker $D$, Geiser A, Lyght M, Flanders KC, Roberts AB, Sporn MB, Ward JM and Karlsson $S$ - Transforming growth factor $\beta 1$ null mutation in mice causes excessive inflammatory tesponse and early death. Proc Natl Acad Sci USA, 1993; 90:770-774.

89. Shull MM, Ormsby I, Kier AB, Pawlowski S, Diebold RJ, Yin M, Allen R, Sidman C, Proetzel G, Calwin D, Annunziala $\mathrm{N}$ and Doetschman $\mathrm{T}$ - Targeted disruption of the mouse tranforming growth factor- $\beta 1$ gene results in multifocal inflammatory disease. Nature, 1992; 359:693-699.

Ristow HJ - BSC-1 growth inhibitor/type b transforming growth factor is a strong inhibitor of thymocyte proliferation. Proc Natl Acad Sci USA, 1986; 83:5531-5533.

51 Kim KJ, Abrams J, Alphonso M, Pearce M, Thorbecke GJ and Palladino MA - Role of endogenously produced interleukin- 6 as a second signal in murine thymocyte proliferation induced by multiplle cytokines: regulatory effects of transforming growth factor $-\beta_{1}$. Cell Innunol, 1990; 131:261-271.

93 Kehrl $\mathrm{JH}_{2}$ Wakefield LM, Roberts AB, Jakowlew S, Alvarez-Mon M, Derynck R, Spon MB and Fauci ASProduction of transforming growth factor $\beta$ by human $T$ lymphocytes and is potential role in the regulation of $T$ cell growth. J Exp Med, 1986; 163:1037-1050.

93 Wahl SM, Hunt DA, Wong HL, Dougherty S, McCartney-Francis N, Wahl LM, Ellingsworth L, Schrnidt JA, Hall $G$, Roberts $A B$ and Sporn $M B$ - Transforming growth factor $\beta$ is a potent inmunosuppressive agent that inhibits IL-1 dependent lymphocyte proliferation. J Immunol, 1988; 140;3026-3068.

94 Quere $\mathrm{P}$ and Thorbecke $\mathrm{GJ}$. Mutiple suppressive effects of transforming growth factor $\beta 1$ on the immune response in chickens. Cell Immanol, 1990; 129:468-477.

95 Mowat A - The regullation of immune responses to dietary proiein antigens. Immunol Tod "1987; 8:93-98.

\$6 Whitacre CC, Gienapp IE, Orosz CG and Bitar DM - Oral tolerance in experimental autoimmune encephalomyeititis. III. Evidence for clonal anergy. J Immunol, 1991; 147:2155-2163. 



\section{Chapter \\ 5}

\section{Staphylococcal enterotoxin B and tumor necrosis factor- $\alpha$-induced relapses of experimental allergic encephalomyelitis: Protection by transforming growth factor- $\beta$ and interleukin-10*}

Giovanna M Crisi*, Laura Santambrogio*, Gerald M Hochwald ${ }^{\oplus}$, Sidney R Smith** Joseph A Carlino*** and $\mathrm{G}$ Jeanette Thorbecke*

Departments of *Pathology, @Neurology and Neuroscience, New York U. School of Med.., New York, NY 10016,**Schering-Plough Research Institute, Kenilworth, NJ 07033-0539 and **** Celtrix Pharmaceuticals, Inc., Santa Clara, CA 95052 


\section{Summary}

A study was made of the ability of the superantigen S. enterotoxin B (SEB) to induce relapses of EAE in SIL mice that had partially or completely recovered from acute EAE We find that a single injection of $0.05 \mathrm{mg}$ SEB iv induces mild relapses in $50 \%$ of such mice. In addition. TNF$\alpha(0.2 \mathrm{mg}$, ip) also induces $\mathrm{EAE}$ relapses in $43 \%$ of $\mathrm{SJL}$ mice when injected $1-2$ mos after recowery. SEB does not induce a second relapse if reinjected when $V B 17 \mathrm{a}^{+} \mathrm{T}$ cells are still partially deleted. In these mice, however, TNF- $\alpha$ is equally effective in inducing relapses as in mice that did not receive SEB previously. We showed earlier that TGF- $\beta$ and TNF- $\alpha$ have antagonistic effects on experimental autoimmune diseases; e.g., in spontaneously relapsing EAE, TGF- $\beta$ and anti-TNF were protective, while anti-TGF- $\beta$ caused disease exacerbation. $\mathbb{L}-10$ is also known to counteract certain TNF effects. We now find that both human $\Pi$ - 10 and TGF- $\beta 2$ lower the incidence of EAE relapses when given simultaneously with SEB or TNF- $\alpha$. The protective effect of TGF- $\beta$ is significant only against relapses induced by SEB (reduced to $9 \%$ ), and that of L-10 only against relapses induced by TNF (reduced to 0\%) with the treatment regimens employed. Neutralizing anti-TGF- $\beta$ does not increase the incidence of SEB-induced EAE relapses. In contrast, anti-IL-10 increases both the incidence and the severity of such relapses. We conclude that TNF production is probably important in causing EAE relapses, but that other aspects of the $\mathrm{SEB}$ induced reactivation of myelin specific $\mathrm{T}$ cells also contribute. Furthermore, endogenous IL-10 rather than TGF- $\beta$ production appears to limit the susceptibility to induction of EAE relapses in this model.

\section{Introduction}

Experimental allergic encephalomyelitis (EAE) is a well characterized model for demyelinating inflammatory diseases of the central nervous system. The pathogenic mechanism of EAE is the activation of specific autoreactive $\mathrm{CD} 4^{*} \mathrm{~T}$ cells to myelin basic protein (MBP) and proteolipid protein (PLP), the major immunogenic proteins in the myelin ${ }^{1,2}$. The effector $T$ cells which recognize MBP belong to the VB8 subset in Lewis rats ${ }^{3.4}$ and in $\mathrm{H}^{\mathrm{U}}$ mice $^{4.5}$. SJLJJ (H2s) mice, in which the V $\beta 8$ gene segments are absent ${ }^{6}$, utilize $V \beta 17 \mathrm{a}^{*}$ and $\mathrm{VB4^{+ }} \mathrm{T}$ cells in response to $\mathrm{MBP}$ and PLP $\mathrm{P}^{78.9}$. The T cell receptor $\beta$ chain usage for PLP recognition in SJL mice is not restricted but heterogeneous, utilizing at least four different $\mathrm{V} \beta \mathrm{s}$, including $\mathrm{V} \beta 17 \mathrm{a}^{10}$. The superantigen (SAG) staphylococcal enterotoxin B (SEB), is a potent $T$ cell activator that stimulates the majority of $T$ cells bearing $V \beta 3,7,8.1-3$, and 17 (reviewed in ${ }^{11}$ ). It has been proposed that SAG's may trigger autoimmune disorders by stimulation of autoreactive $T$ cells ${ }^{11}$. Indeed, SEB is able to induce EAE symptoms in PLJ mice that have previously been immunized with MBP in CFA and have recovered from their first acute EAE episode ${ }^{12,13}$.

Although no such effect of SEB was found in SJL mice by Brocke et al. ${ }^{13}$, we have found to the contrary that mild relapses do occur in approximately $50 \%$ of SJL/J mice injected with SEB $1-2$ months after immunization with spinal cord homogenate in $C_{F A}{ }^{14}$. At least one of the V $\beta$ 's involved in PLP recognition in SJUJ mice, VB17a, is also known to interact with SEB. In I-E $E^{+}$F1 hybrids of SJL/J mice V 317 a is deleted ${ }^{15}$, but V $\beta 8^{+}$T cells are present and able to respond to PLP 
In the context of $\mathrm{H}_{2} \mathrm{~s}^{16}$.

Tumor necrosis factor (TNF) production is correlated with the ability of cell lines to transfer $\mathrm{EAE}^{17,18}$. Anti-TNF, as well as TGF- $\beta_{1}$ and TGF- $\beta_{2}$, protect against $\mathrm{EAE}$ in acute, relapsing ${ }^{19_{2} 20}$ and adoptive EAE ${ }^{21,22}$. In contrast to TNF, TGF- $\beta$ has a physiological role in preventing inflammatory processes and autoaggression, as evidenced by early death as a result of excessive inflammatory responses in $T G F-\beta_{1}^{-1-}$ (knockout) mice ${ }^{23,24}$. In many respects TGF- $\beta$ and TNF have antagonistic effects ${ }^{25,26,27}$. For instance, while TNF activates macrophages, TGF $\beta$ (as well as TL-10) cause macrophage deactivation ${ }^{27,28}$. Both TGF- $\beta$ and $\mathrm{L}-10$ inhibit TNF- $\alpha$ : production $^{2930}$. Augmented synthesis of $\mathrm{LL}-10$ in spinal cord is associated with the recovery phase from EAE in SJL mice ${ }^{31}$.

In the present study we have examined further the ability of SEB and TNF $\alpha$ to induce relapses in SJL mice after recovery from acute EAE. We have also investigated the ability of the superantigen to induce relapses in $\mathrm{I}-\mathrm{E}^{+} \mathrm{F} 1$ hybrid mice who lack $\mathrm{V} \beta 17 \mathrm{a}^{+} \mathrm{T}$ cells. The results will show that SEB and TNF- $\alpha$ are approximately equally effective in inducing EAE relapses. However, while TNF-induced relapses are inhibited by $\mathrm{IL}-10$, TGF- $\beta$ is more effective in preventing SEB-induced relapses.

\section{Materials and methods}

Mice

Female SJL/J and male AKR mice were purchased from the Jackson Laboratories (Bar Harbor, ME). Male BALB/c mice were bought from Charles River Labs. (Wilmington, MA). SIL $x$ $\mathrm{BALB} / \mathrm{c}$ and SJL $\times$ AKR F1 mice were bred in the animal quarters of NYU Medical Center. Paralyzed mice were afforded easy access to food and water.

\section{Antigens}

Proteolipid protein peptide 139-151. (PLP) was purchased from Immuno-Dynamics Inc. (La Jolla, CA). Murine spinal cords that were obtained by insufflation were rapidly homogenized, lyophilized and kept at $-70^{\circ} \mathrm{C}$ until use (MSCH). SEB was purchased from Toxin Technologies, Inc. (Sarasota, FL).

\section{Induction of EAE}

Six to eight weeks old mice were immunized with MSCH or PLP in adjuvant as previously described $^{20}$. Each mouse received subcutaneous injections into the hind footpads and nape of the neck with a total of $0.1 \mathrm{ml}$ of an emulsion containing $0.2 \mathrm{mg} \mathrm{M}$. tuberculosis H37 RA and either $200 \mathrm{mg}$ PLP or $4 \mathrm{mg}$ lyophylized MSCH in CFA (Difco Labs., Detroit, MD). The immunization was followed after $24 \mathrm{~h}$ by a single iv injection of $400 \mathrm{ng}$ of pertussigen or at 24 and $48 \mathrm{~h}$ by iv injections of $200 \mathrm{ng}$ pertussigen each (LIST Biol. Labs. Inc., Campbell, CA). A lotal dose of 400 ng pertussigen was preferred for these experiments, because it was desirable for the experimental protocol that the mortality durimg the acute phase of EAE was low. Clinical signs of EAE developed in $\mathbb{1 0}$ to 15 days. 


\section{Clinical evaluation}

Mice were observed daily for clinical signs of disease until days 30 to 35 postimmunization. Clinical signs were scored according to their clinical severity as follows: grade 0 , no symptoms; grade 1, limp tail; grade 2, limp tail and hind limb weakness (waddling gait); grade 3, severe hind limb weakness and mild forelimb weakness: grade 4 , total paralysis of hind legs, and moderate forelimb weakness; grade 5, complete paralysis and moribund. Mild disease signs had to be present for three consecutive days to be considered positive.

\section{Reactivation of EAE}

Mice that had recovered from the acute disease to a disease severity with a clinical score of $\leq 2$ (approximately 1 to 2 months after immunization), were injected with 40 to $50 \mathrm{mg}$ of SEB iv or 200 ng of recombinant murine TNF- $\alpha$ ip. Recombinant murine TNF- $\alpha$ was produced in $\underline{E}_{\text {. coli }}$ and had a specific activity of $7 \times 10^{7} \mathrm{U} / \mathrm{mg}$ as determined by a cytotoxicity assay using the murine cell line L-M (kindly supplied by Dr. Palladino MA, Genentech Inc, So. San Francisco, $\mathrm{CA}^{32}$

The mice were observed for development of relapsing disease up to 10 days following the SEB or TNF injection. Relapses of EAE usually occurred within 5 days. Mice were said to exhibit a relapse when their clinical EAE score increased and remained higher for at least three consecutive days.

\section{Cytokine treatment}

One day prior to the administration of either SEB or TNF- $\alpha$ mice received $1 \mathrm{mg}$ recombinant simian TGF- $\beta_{2}$ (Celtrix Pharma- ceuticals Inc) or $1 \mathrm{mg}$ recombinant human $\mathrm{L}-10$ (ScheringPlough Research Institute) ip during three consecutive days. Other mice received $0.5 \mathrm{mg}$ of antiTGF- $\beta$ ip $\left[2 G 7\right.$ : neutralizes TGF- $\beta_{1}, T_{G F}-\beta_{2}$, and TGF- $\beta_{3}{ }^{33}$; kindly donated by Dr. Brian $M$. Fendly, Genentech, Inc.], or rat IgG1 anti-1L-10 $\left(2 \mathrm{~A} 5^{34}\right)$.

\section{Immunofluorescence analysis}

Peripheral blood was collected directly into a Eppendorf tube containing heparin. Leukocytes were separated by Lympho-Paque density. gradient centrifugation (Nyegaard \& Co., Oslo, Norway). Cells from F1 mice were stained with biotin-labeled anti-VB8.2 mAb [MR5.2. purchased from Pharmingen, San Diego, CA] followed by Streptavidin-R613 (Gibco BRL, Gaithersburg, MD), and cells from SJL mice with FTTC-labeled anti-VP17a mAb (KJ23a ${ }^{36}$ ). Cells were analyzed in a FACS can flow cytometer (Becton Dickinson, Mountain View, CA).

\section{Histopathology}

Mice were killed 9 days after induction of relapses. Brains were fixed in $10 \%$ buffered formalin. Coronal sections were prepared from the cerebrum, cerebellum and brainstem. Paraffin sections were stained with hematoxylin eosin.

\section{Statistical analysis}

Comparison of the mean day of onset and the max score between two groups of mice were 
analyzed by the Sudent's t test. Incidences of EAE and of mortality were compared by use of the $\mathrm{Chi}^{2}$ test.

\section{Results}

\section{Enterotoxin B induced EAE relapses in SJL mice and F1 hybrids.}

SIL mice, immunized with MSCH in CFA, showed a high incidence of EAE with peak morbidity on days 12-16. Approximately $15 \%$ of the mice succumbed, some remained partially paralyzed but most of the mice recovered. As can be seen in Fig. 1,57\% of mice injected with SEB iv 1-2 months after recovery from acute $E A E$ developed a mild relapse within $2-5$ days. They then recovered again within the next two weeks. Control mice, injected with saline did not develop relapses at this time (0/8; not shown). Six mice, that had been injected with SEB on day 52 , were reinjected with SEB three weeks later but developed no further relapses (Fig. 1). In view of the known responsiveness of $\mathrm{V} \beta 17 \mathrm{a}^{+} \mathrm{T}$ cells to both myelin proteins ${ }^{4,5}$ and to $\mathrm{SEB}^{11}$, the percentages of $\mathrm{VB} 1 \mathrm{Ta}^{+} \mathrm{T}$ cells in the peripheral blood of these mice were determined. Three days after injection of SEB, $8.6 \pm 1.2 \%$ of PBL were VB17a ${ }^{*}$, which is within the normal range for SJL

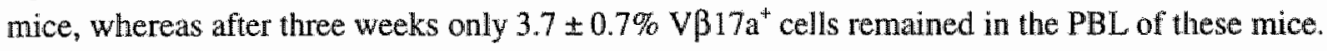
Similar experiments were performed in SJL $x$ BALB/c and SJL x AKR FI mice (Fig. 2).

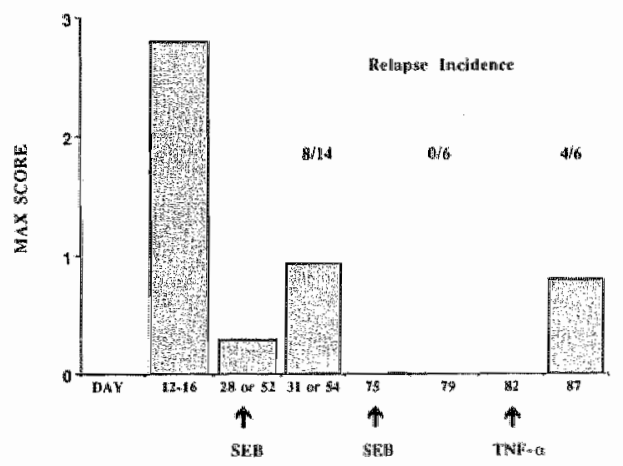

Figure 1: EAE relapses induced by SEB and TNF- $\mathrm{E}$ in SIL/N mice. After recovery from acute EAE, 14 mice were injected with $50 \mathrm{mg}$ SEB iv, 6 at one and 8 at two mos after immunization with PLP in CFA. The mean max. disedse score $\mathrm{SD}$ in acute EAE for these mice was $2.79 \pm 0.58$, which at the time of SEB injection had gone down to $0.29 \pm$ 0.43 . After $\$ \mathrm{~EB}$ injection the disease score was $0.93 \pm 0.73$ for the total group $(\mathrm{p}<0.01)$, and $1.37 \pm 0.5$ for the 8 mice that showed a relapse. Six mice were reinjected with SEB three weeks after the first injection: no relapses were seen. TNF- $\alpha$ was injected into these mice one week later and induced relapses to a mean max. score of $0.8 \pm 0.7$ (new. $\mathrm{p}=0.02)$.

Athough both these FI hybrids possess the SEB reactive $V \beta 8^{+} \mathrm{T}$ cells, which SJL mice lack, the SEB induced relapses were of the same order, magnitude and frequency as in SJL mice 150 and $67 \%$, respectively). The $\mathrm{V} \beta 8^{*} \mathrm{~T}$ cells responded by increasing within three days from $5.6 \pm 0.9 \%$ to $18.3 \pm 3.5 \%(n=4)$ in the peripheral blood of SJL $\times$ AKR mice. 


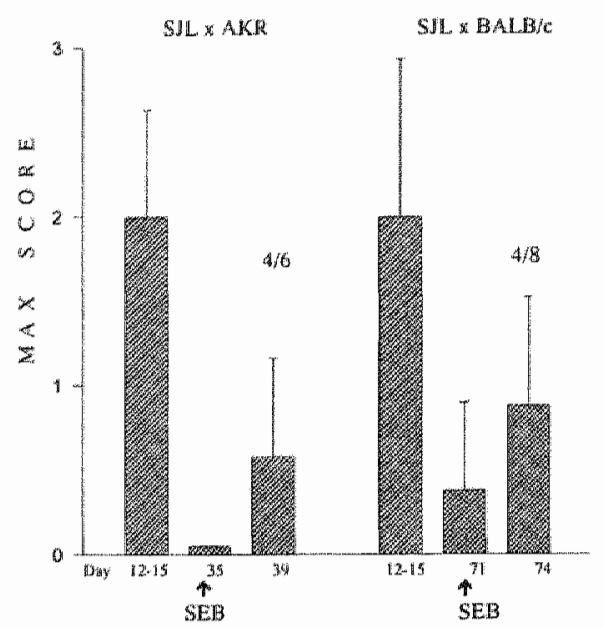

Figure 2: SEB induced EAE relapses in F1 hybrids of SJL/J mice. After recovery from acute EAE, groups of SIL $\times$ AKR and SIL $\times$ BALB/c mice were injected with SEB (50 mg iw). The bars represent the mean max. EAE score \pm SD (day 12-15) during acute EAE for this group of mice, the remaining disease score at the time of SEB injection (day 35 or 71 ), and the mean max. score after SEB (day 39 or 74 ) including both relapsing and nonrelapsing mice.

\section{TNF $-\alpha$ induced relapses of EAE in SJL mice.}

The mechanism by which SEB induces an EAE relapse could be by activating specific, myelin reactive $\mathrm{T}$ cells, causing them to migrate into the central nervous system. Alternatively, the cytokines released by SEB-activated $T$ cells might cause a reactivation of the residual mononuclear cells in CNS infiltrates. Prominent among those cytokines would be TNF, particularly as its production correlates with the encephalitogenic capacity of myelin specific $T$ cells $^{18}$. In addition, SEB can augment adoptive EAE only when injected together with encephalitogenic but not with non-encephalitogenic MBP-specific T cell clones ${ }^{13}$. We therefore investigated whether ip injection of TNF- $\alpha$ would mimic the effect of SEB. A dose of $200 \mathrm{ng}$ of this TNF- $\alpha$ preparation was selected as the highest dose tolerated by the mice without obvious toxic effects ${ }^{37}$. The results in Table 1 show that the relapse rates in mice injected with TNF- $\alpha$ or SEB were very similar: 43 vs $50 \%$. The severity of the relapses induced by SEB and TNF were also quite similar. The mean disease severity score in the animals exhibiting relapses increased from $0.4 \pm 0.6$ to $1.0 \pm 0.5$ after SEB $(p=0.0002, n=27)$ and from $0.1 \pm 0.3$ to $0.9 \pm 0.5$ after TNF$\alpha(p<0.0001, n=23)$. Contrary to what has been reported by others ${ }^{12,13}$, mice that did not exhibit symptoms of EAE during the acute phase of the disease also failed to show relapses to SEB or TNF. Such mice (approximately $8 \%$ ) were therefore excluded from the results reported in Table 1.

Histopathological analysis of the brains did not reveal any differences between mice with and without EAE relapses. The frequency and size of perivascular infiltrates observed was extremely variable, but similar in the relapsing and non-relapsing mice. The effect of relapse inducing agents was, therefore, difficult to evaluate histopathologically. 


\section{Table 1}

\section{Protection against SEB or TNF induced relapses of EAE}

\begin{tabular}{|c|c|c|}
\hline \multirow[t]{2}{*}{ Additional Treatment ${ }^{\text {a }}$} & \multicolumn{2}{|c|}{ Incidence of Relapses Induced By: } \\
\hline & SEB & TNF- $\alpha$ \\
\hline None & $27 / 54(50 \%)$ & $23 / 53(43 \%)$ \\
\hline TGF $-\beta 2,3 \times 1 \mathrm{mg}$ & $2 / 22(9 \%)^{\text {dh }}$ & $4 / 19(21 \%)^{17}$ \\
\hline $\mathrm{LL}-10,3 \times 1 \mathrm{mg}^{\mathrm{c}}$ & $7 / 22 *(32 \%)$ & $0 / 29(0 \%)^{51}$ \\
\hline
\end{tabular}

Three daily injections ip, starting on the day before SEB or TNF $\alpha$.

SEB 40-50 mg iv; TNF- $200 \mathrm{mg}$ ip.

In this group $5 / 15$ mice receiving human $\mathrm{L}-10$ and $2 / 7$ mice receiving murine $\mathrm{LL}-10$ got relapses

Statistical significance of differences between group designated by the same footnotes was assayed by Chi 2 test: $\mathrm{p}=0.0007 ;{ }^{\mathrm{e}} \mathrm{p}=\mathrm{NS} ;{ }^{*} \mathrm{p}<0.0001 ; \mathrm{p}=0.02$.

\section{Protection against SEB or TNF- $\alpha$ induced EAE relapses by other cytokines.}

In previous work we and others found that both anti-TNF- $\alpha$ and TGF- $\beta$ ameliorate, while antiTGF- $\beta$ and TNF tend to exacerbate experimental autoimmune diseases ${ }^{20,37,38,39,40}$. We therefore examined whether anti-TGF- $\beta$ and TGF- $\beta$ would affect SEB and TNF induced EAE relapses. The results in Table 1 demonstrate that three daily injections of $1 \mathrm{mg}$ TGF- $\beta_{2}$ provided a significant protection against SEB induced relapses.

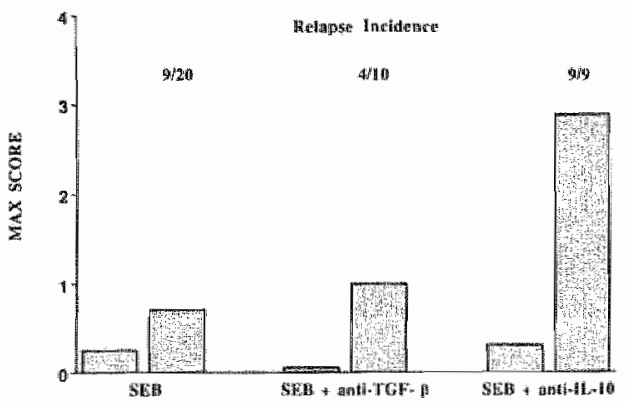

Higure 3: Efrect of anti-TGF-P and anti-L-10 on SEB induced FA $\mathrm{E}$ relapses. A group of 49 mice was allowed to recover from aculte EAE. On day 0 ( 42 or 59 days post immunization with PLP in CFA), SEB (40 mg iv) was dinjected into all the mice. 10 of the mice additionally received $0.5 \mathrm{mg}$ anti- TGF- $\beta(2 G 7)$ ip on days -1 and 0,9 of the mice additionally received $0.5 \mathrm{mg}$ of anti-1L-10 (2A5) on day -1 . The bars represent the mean $\mathrm{EAE}$ scores \pm SD for the three groups, including both relapsing and nonrelapsing mice, at the tirne of SEB injention and at the time of max. EAE relapse. The severity of relapses in the anti-1L-10 treated group was significanily greater than in the comtrol $(p<0.001)$ or anti-TCIF- $\beta$ reated group $(p=0.03)$.

While the incidence of TNF-a induced relapses was also lowered by TGF- $\beta$, this effect was not statistically significant (Table 1). In an additional experiment, mice received either SEB alone or $\mathrm{SEB}$ with neutralizing $\mathrm{mAb}$ to $\mathrm{TGF}_{-} \beta(2 \mathrm{G} 7 ; 0.5 \mathrm{mg}$, ip) or $\mathrm{LL}-10(2 \mathrm{~A} 5 ; 0.5 \mathrm{mg}$, ip) (Fig. 3). The incidence of EAE relapses was 9/20 (EAE score increment $0.7 \pm 1.3$ ) after SEB alone, 4/10 (EAE 
score increment $1.0 \pm 1.7)$ after anti-TGF- $\beta+\$ E B$, and $9 / 9$ (EAE score increment $2.9 \pm 1.8)$ after anti-IL 10 + SEB (Fig.3). Thus, although there was no significant effect of anti-TGF- $\beta$, both the incidence $(p=0.005)$ and severity $(p<0.001)$ were significantly increased by the anti- $1 \mathrm{~L}-10$. The effect of anti- $\mathbb{L}-10$ on TNF- $\alpha$ induced relapses was therefore also examined, but no increase in severity or incidence of EAE relapses was cobserved: $4 / 11$ with TNF- $\alpha$ alone and $2 / 12$ after antiIL $-10+$ TNF $-\alpha$

\section{Discussion}

The present studies show that TNF- $\alpha$ can mimic the EAE relapse inducing effect of SEB in SJL mice. It has been suggested that bacterial SAG might cause autoimmune diseases by activating autoreactive $T$ cells, causing these cells to enter target organs containing the autoantigen and starting a self-perpetuating inflammatory process" ${ }^{\prime \prime}$. Clearly, neither SEB nor TNF induces EAE in normal mice. Therefore, for the induction of EAE relapses the mice need to possess expanded myelin (PLP)-specific $T$ cell clones in the periphery and/or mononuclear cell infiltrates in the central nervous system. The occurrence of spontaneous EAE in MBP-specific TCR transgenic mice only in relatively unsanitary, but not in clean animal quarters also suggests that bacterial and/or wiral constituents have a significant influence on autoimmune phenomena. Activated, rather than resting $\mathrm{T}$ cells, are much more likely to enter target organs by adhering to and transversing the wall of small bllood vessels. The observation that TNF- $\alpha$ can induce EAE relapses suggests that viral infections and bacterial components such as endotoxins, both of which induce Hymphotoxin and TNF- $\alpha$ synthesis, might play an important role by promoting the expression of adhesion molecules ${ }^{41}$.

In the present experiments, SJL mice that failed to respond to a second injection of SEB at a time when their circulating VB17 ${ }^{*} \mathrm{~T}$ cell numbers were low, did produce relapses in response to TNF$\alpha$. Thus, the decrease in circulating VB17 $\mathrm{a}^{+} \mathrm{T}$ cells in these mice (see above) did not prevent the TNF-induced relapses, although a depletion of SEB responsive $T$ cells apparently did interfere with the ability of SEB to induce relapses. This suggests that TNF reactivates the destructive effect of inflammatory cell infiltrates in the CNS. In addition, TNF can directly damage oligodendrocytes $^{42}$ and promote the production of toxic intermediates, such as nitric oxide, by monocytes ${ }^{43}$. Increased TNF production is also associated with enhanced disease activity in multiple sclerosis ${ }^{44,45}$. Indeed, relapses of multiple sclerosis are frequently associated with clinical infections ${ }^{46}$ which may be accompanied by TNF production.

From the results of our previous work ${ }^{19,20,38}$, the protective effect of TGF- $\beta$ against acute EAE and spontaneous EAE relapses appeared to be due to the interference with the entry of sensitized $T$ cells into the CNS, rather than with the production of myelin specific $T$ cells. The antagonism between TNF and TGF- $\beta$ in autoimmune diseases could be due to opposing influences on the sensitized $T$ cell migxation into target organs via effects of these cytokines on adhesion molecule expression $^{41,47}$ and/or to reciprocal inhibition of cytokine synthesis. The present observation that TGF- $\beta$ significantly lowers the incidence of SEB-induced relapses but not that of TNF- $\alpha$ induced relapses, suggests that one important aspect of the TGF- $\beta$ effect is the inhibition of TNF synthesis, rather than the neutralization of TNF activity. Both TNF ${ }^{48}$ and IFN- $\gamma^{49}$ are induced by 
SEB and could be mediators of SEB-induced relapses. TGF- $\beta$ is known to inhibit TNF synthesis by inflammatory cells ${ }^{25}$, astrocytes ${ }^{50}$ and microglia ${ }^{51}$. In addition it inhibits IFN- $\gamma$ symthesis by activated $\mathrm{T}$ cells ${ }^{52}$. Macrophages are activated to produce free radicals by IFN- $\gamma$ and TNF- $\alpha$. It has been shown that TGF- $\beta$ can inhibit such activation of macrophages and the induction of NO synthase by these cytokines, primarily when present during the induction phase ${ }^{27}$. In addition, it can reduce the production of free radicals in microglial cells ${ }^{33}$.

A highly significant degree of protection against TNF induced relapses was obtained with IL-10, whereas the decreasing effect of this cytokine on $\mathrm{SEB}$ induced relapses was not statistically significant. In fact, IL-10 was significantly more effective at protecting against the induction of relapses by TNF than was TGF- $\beta$. Similar to TGF- $\beta$, IL-10 also inhibits TNF productio ${ }^{54.55}$, activation of macrophages ${ }^{28}$ and free radical formation by monocytes ${ }^{36}$. In addition, IL-10 induces the release from monocytes of TNF-R, both the $p 55$ and the p75 chains ${ }^{57,58}$, while TGF- $\beta_{2}$ does not have any effect on TNF-R expression ${ }^{58}$. The combined IL-10 effects of lower TNF-R expression on monocytes/macrophages and of increasing circulating. TNF- $R$, able to block the activity of TNF, could be instrumental in the prevention of TNF- $\alpha$ induced EAE relapses and might explain why $\mathrm{IL}-10$ is more effective than $T G F-\beta_{2}$ in this respect.

It was noted in the protection against endotoxemia by $\mathrm{IL}-10$, that the lethal effects of LPS in mice with augmented IFN- $\gamma$ production could not be prevented in spite of inhibition of TNF production $^{55}$. Moreover, IL-10 is not effective in inhibiting IFN- $\gamma$ production by acutely activated $T$ cells. It is possible that synergy between SEB induced IFN- $\gamma^{49}$ and TNF ${ }^{48}$ production plays an important role in the induction of EAE relapses. The relative inefficiency of $\mathbb{L}-10$ as compared to TGF- $\beta$ in the inhibition of the production of IFN- $\gamma$ and/or other cytokines could explain the greater protection against $S E B$ induced $E A E$ relapses by $T G F-\beta$.

A role for $\Pi 1-10$ in the recovery from EAE has been suggested on the basis of its enhanced presence in the CNS of recovering mice ${ }^{3 !}$. An important function for endogenous $\mathrm{L}-10$ production in the protection against SEB-induced relapses is also suggested by the finding in the present study that anti-1L-10 increased the incidence and severity of SEB-but not of TNF-induced relapses. No significant effect of anti-TGF- $\beta$ was detected on SEB-induced relapses. This was surprising, since in previous work the same dose of this ant--TGF- $\beta$ caused a significant increase in the severity of disease, when it was administered during the induction of acute $\mathrm{EAE}^{20}$, and an increase in relapses when administered during the course of spontaneously relapsing EAE ${ }^{20}$. In more recent unpublished studies we have found that anti-TGF $\beta$ can provoke acute EAE development even in mice immunized with PI.P without pertussigen that, without anti-TGF- $\beta$, do not show any signs of disease. It appears possible that both $\mathrm{L}-10$ and $\mathrm{TCF}-\beta$ contribute to the maintenance of an anti-inflammatory state with respect to autoimmune disease, IL-10 more locally within tissue infiltrates of mononuclear cells, and TGF- $\beta$ more in the prevention of infiltrate formation.

\section{Acknowledgements}

The expert assistance of Betty Tomasello is gratefully acknowledged. 


\section{References}

( Chow C-H, Shapira R and Fritz RB - Encephalitogenic activity of small form of myellin basic protein in the SJUJ mouse. J Immunol, 1983; 130:2183.

2 Lees MB, Kuchroo VK and Sobel RA - Myelin proteolipid protein: its role in experimental allergic encephalomyelitis. Int Pediatr, $1991 ; 6: 84$.

3 Bums FR, Li XB, Shen N, Offner H, Chou YK, Vandenbark AA, and Heber KE - Both rat and mouse T cell receptors specific for the encephalitogenic determinant of myelin basic protein use similar $V \alpha$ and $V B$ chain genes even though the rajor histocorripatibility complex and encephalitogenic determinants being recognized are different. J Exp Med, 1989; 169:27.

4 Zamvil, SS and Steinman L. The T lymphocyte in experimental allergic encephalomyelitis..An Rev Immunol, $1990,8: 579$.

5 Kumar $\mathrm{V}$ and Sercarz $\mathrm{E} \cdot \mathrm{T}$ cell regulatory circuitry: antigen- specific and TCR-idiopeptide-specific $\mathrm{T}$ cell interactions in EAE [Review]. Int Rew Immunol, 1993; 9:287.

6 Behlke MA, HS Chou, K Huppi and Loh DY - Murine T cell receptor mutants with deletions of $\beta$-chain variable region genes. Proc Natl Acad Sci USA, 1985; 83:767.

7 Sakai KA, Sinha AA, Mitchell DJ, Zamvil SS, Rothbard JB, McDevitt H and Steinman L -Involvement of distinct murine T-cell receptors in the autoimmune encephalitogenic response to nested epitope of myelin basic protein. Proc Natl Acad Sci USA, 1988; 85:8608.

8 Padula SJ, Lingenheld EG, Stabach PR, Chou CH, Kono DH and Clark RB - Identification of encephalitogenic VP-4-bearing $T$ cells in SIL mice: further evidence for the $V$ region disease hypothesis. I Immunol, 1991; $146: 879$.

9 Yamamura $Y$, Kondo T, Sakanaka S, Kozowska M, Geng T-C, Takahashi K and Tabira T - Analysis of T cell antigen receptors of myelin basic protein specific $T$ cells in SJL/ mice demonstrates an a chain CDR3 motif associated with encephalitogenic T cells. Int Immunol, 1994; 6:947.

10 Kuchroo VK, Sobel RA, Laning JC, Martin CA, Greenfield E, Dorf ME and Lees MB - Experimental allergic encephalomyelitis mediated by cloned $T$ cells specific for a synthetic peptide of myelin proteolipid protein. J limmunol, 1992; 148:3776.

It Marrack $P$ and Kappler $J$ - The staphylococcal enterotoxins and their relatives. Science, 1990; 248:705.

12 Schiffenbauer J, Johnson HM, Butfiloski EJ, Wegrzyn L and Soos JM - Staphyloccocal enterotoxins can reactivate experimental allergic encephalomyelitis. Proc Nat Acad Sci USA, 1993; 90:8543.

13 Brocke $S_{*}$ Gaur A, Piercy C, Gautam A, Gijbels K, Fathman CG and Steinman L - Induction of relapsing paralysis in experimental autoimmune encephalomyelitis by bacterial superantigen. Nature, 1993; 365:642.

14: Santanbrogio L, Crisi GM, Hochwald GM, Ryan T and Thorbecke GJ - Tolerogenic forms of auto-antigens and cytokines in the induction of resistance to experimental allergic encephalomyelitis. I Neuroimmunol 1995 ; $58: 211$.

1.5 Wade T, Bill J, Marrack PC. Pallmer E and Kappler JW - Molecular basis for the nonexpression of V $\beta$ in some strains of mice. J Inumunol, 1988; 141:2165.

16 Kuchroo VK, Collins M, Al-Sabbagh A, Sobel RA, Whitters MJ, Zamvil SS, Dorf ME, Hafler DA, Seidman JG, Weiner HL and Rimm IJ - $T$ cell receptor (TCR) usage determines disease susceptibility in experimental autommune encephalonyelitis: Studies with TCR VB 8.2 transgenic mice. J Exp Med, 1994: 179:1659.

$1 \%$ Ando DG, Clayton J, Kono D, Urban JL and Sercarz EE - Encephalitogenic T cells in the B10.PL model of experimental allergic encephalomyelitis (EAE) are of the Th-1 lymphokine subrype. Cell Immunol, 1989; $124: 134$.

is Powell MB, Mitchell D, Lederman T, Buckmeier J, Zamvil SS, Graham M, Ruddle NF and Steinman L Lymphotoxin and tumor necrosis factor-alpha production by myelin basic protein-specific $T$ cell clones correlates with encephalomitogenicity. Int Immunol, 1990;2:539.

19 Santambrogio L, Hochwald GM, Leu CH and Thorbecke GJ - Antagonistic effects of endogenous and exogenous TGF- $\beta$ and TNF on auto-immune diseases in mice. Immunopharm and Immunotoxicol, 1993; 15:461. 
20 Santambrogio L, Hochwald GM, Saxena B. Leu CH, Martz JE, Carlino JA, Ruddle NH, Palladino MA, Gold LI and Thorbecke Gll - Studies on the mechanisms by which TGF- $\beta$ protects against allergic encephalonyelitis: antagonism between endogenously produced TGF- $\beta$ and TNF. J Immunol, 1993; 151:1116.

21 Ruddle NH, Bergman CM, McGrath KM, Lingenheld EG, Grunnet ML, Padula SI and Clark RB - An antibody to lymphotoxin and turnor necrosis factor prevents transfer of experimental allergic encephalonnyelitis. I Exp Med, $1990 ; 172: 1193$.

22 Selmaj $\mathrm{K}$, Raine CS and Cross AH. Anti-tumor necrosis factor therapy albrogates autoimmune dernyelination. Ann Neurol, 1991; 30:694.

23. Kulkarni $A B$, Huh $C-G$, Becker $D$, Geiser A, Lyght $M$. Flanders KC, Roberts AB, Sporn MB, Ward $M$ and Karlsson S - Transforming growth factor BI null mutation in mice causes excessive inflamnitatory response and early death. Proc Natl Acad Sci USA, 1993; 90:770.

2. Shull MM, Ormsby I, Kier AB, Pawlowski S, Diebold RJ, Yin M, Allen R, Sidman C, Proetzel G, Calwin D, Amnumziata $N$ and Doetschman $T$ - Targeted disruption of the mouse tranforming growth facior- $\beta / 1$ gene results in multifocal inflammatory disease. Nature, 1992:359:693.

25 Espevik T, Figari IS, Ranges GE and Palladino MA Jr - Transforming growth factor $\beta_{1}$ (TGF- $\beta_{1}$ ) and recombinant human tumor necrosis factor-\& reciprocally regulate the generation of lymphokine-activated killer cell activity. Comparison between matural porcine platelet-derived TGF- $\beta_{1}$ and TGF- $\beta_{2}$, and recombinant human TGF- $\beta_{1}$. J Immunol, 1988; 140:2312.

26 Epstein SP, Baer RL, Thorbecke GJ and Belsito DV - Immunosuppressive effects of transforming growth factor B: Inhibition of the induction of Ia antigen on Langerhans cells by cytokines and of the contact hypersensitivity response. J Invest Dernatol, 1991; 96:832.

27 Ding A, Nathan $\mathrm{CF}_{x}$ Graycar J, Derynck R, Stuehr DJ and Srimal S . Macrophage deactiwating factor and transforming growth factors- $\beta_{1}$, and $-\beta 2$, and $-\beta 3$ inhibit induction of macrophage nitrogen oxide synthesis by IFN- $\gamma$. J Immunol, 1990; 145:940.

28 Bogdan $C_{\text {, Vodovotz }} \mathrm{Y}$ and Nathan $\mathrm{C}$ - Macrophage deactivation by interleukin 10. I Exp Med, 1991; 174:1549.

29 Chantry $D_{0}$ Turner M, Abney E and Feldmann M - Modulation of cytokine production by transforming growth factor-| $\beta 1$. J Immunol, 1989; 143,4295.

30 Waal de Malefyt R, Abrams J, Bennett B. Figdor C and Vries de JE - Interleukin 10 (II- 10) inhibits cytokine symthesis by human monocytes: an autoregulatory rolle of IL-10 produced by monocytes. J Exp Med, 1991; 174:1209.

31 Kennedy MK, Torrance DS, Picha KS and Mohler KM - Analysis of cytokine mRNA expression in the central nervous system of mice with experimental autoimmune encephalomyelitis reveals that IL-10 mRNA expression correlates with recovery. IImmunol, 1992; 149:2496.

32 Pennica D, Hayflick JS, Bringman TS, Palladino MA and Goeddel DV - Cloning and expression in Escherichia coli of the CDNA for murine tumor necrosis factor. Proc Natl Acad Sci, 1985; 82:6060.

${ }^{33}$ Lucas $\mathrm{C}$, Bald LN, Fendly BM, Morat Worms M, Figari IS, Patzer EJ and Palladino MA - The autoerine production of transforming growth factor- $\beta$, during lymphocyte aclivation. J Immunol, 1990; 145:1415.

3* Abrams JS, Roncarolo M-G, Yssel H. Andersson U, Gleich GJ and Silver JE - Strategies of anti-cytokine monoclonal antibody development: immunoassay of IL-10 and IL-5 in clinical samples. Inmunol Rev, 1992; $127: 5$.

35 Kanagawa $\mathrm{O}$ - Antibody-mediated activation of $\mathrm{T}$ cell clones as a method for screening hybridomas producing antibodies to the $T$ cell receptor. I Immunol Meth, 1988; 110:169.

36 Kappler JW, Wade T, White J, Kushnir E, Blackman $M$, Bill J, Roehm $N$ and Marrack P - A T cell receptor VB segment that imparts reactivity to a class II major histocompatibility complex product. Cell, 1987; 49:263.

37 Thorbecke GJ, Strah R, Leu CH, Kuruwilla AP, Hardison AM and Palladimo MA - Involvement of endogenous TNF- $\alpha$ and TGF- $\beta$ produced during the induction of collagen type II arthritis in mice. Proc Natl Acad Sci USA. $1992 ; 89: 7375$. 


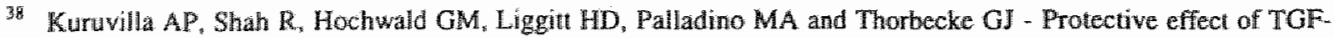
$\beta_{1}$ on experimental autoimmune diseases in mice. Proe Natl Acad Sci, 1991; 88:2918.

3g Racke MK, Cannella B, Albert P, Spon M, Raine CS and McFarlin DE - Evidence of endogenous regulatory function of transforming growth factor-b1 in experimental allergic encephalomyelitis. Int Immunol, 1992; 4:615.

40. Johns LD and Srirum S - Experimental allergic encephalomyelitis: Neutralizing antibody to TGFB1 enhances the clinical severity of the disease. J Neuroimmunol, 1993; 47:1.

4) McCarron RM, Wang L, Racke MK, MeFarlin DE and Spatz M - Cytokine-regulated adhesion between encephalitogenic T lymphocytes and cerebrovascular endothelial cells. J Neuroimmunol, 1993; 43:23.

42 Selmaj KW and Raine CS - Tumor necrosis factor nediates myelin and oligodendrocyte damage in virro. Ann Neurol, 1988; $23: 339$

43 Ding AH, Nathan CF and Stuehr DJ - Release of reactive nitrogen intermediates and reactive oxygen intermediates from mouse peritoneal macrophages. J Immunol, 1988; 141:2407.

44 Beck I, Rondot $\mathrm{P}$, Catinol L, Fatcoff E, Kirchner $\mathrm{H}$ and Wietzerbin J - Increased production of interferon gamma and tumor necrosis factor precedes clinical manifestation in multiple sclerosis: do cytokines trigger off exacerbations? Acta Neurol Scand, 1988; 78:318.

45 Rieckmann P, Albrecht M, Kitze B, Weber T, Tumani H, Broocks A, Luer W, Helwig A and Poser S - Tumor necrosis factor- $\alpha$ messenger RNA expression in patients with relapsing-remitting multiple sclerosis is associated with disease activity. Ann Neurol, 1995; 37:82.

46 Panitch HS - Influence of infection on exacerbations of multiple sclerosis. Amn Neurol, 1994; 36:S25.

47 Gamble JR, Khew-Goodall $Y$ and Vadas MA - Transforming growth factor- $\beta$ inhibits E-selectin expression on human endothelial cells. J Immunol, 1993; 150:4494.

48 Fast DJ, Schlievert PM and Nelson RD - Toxic shock syndrome associated staphylococcal and streptococcal pyrogenic toxins are potent inducers of turnor necrosis factor production. Infect Immun ${ }_{n} 1989 ; 57: 291$.

49 Yan X-J, Li X-Y, Imanishi K, Kumazawa $Y$ and Uchiyama T - Study of activation of murine T cells with bacterial superantigens. J Immunol, 1993; 150:3873.

50 Benveniste EN, Kwon J, Chung WJ, Sampson J, Pandya K and Tang LP - Differential modulation of astrocyte cytokine gene expression by TGF- $\beta^{1}$. I Immunol, 1994; 153:5210.

51 Suzumura A, Sawada M, Yamamoto H and Marunouchi T - Transforming growth factor- $\beta$ suppresses activation and proliferation of microglia in vitro. J Immunol, 1993; 151:2150.

32 Holter W, Kalthoff FS, Pickl WF, Ebner C, Majdic O, Kraft D and Knapp W - Transforming growth factor- $\beta$ inhibits IL-4 and IFN- $\gamma$ production by stimulated human T cells. Int Immunol, 1994; 6:469.

53 Merrill JF, Ignarro LJ, Sherman MP. Melinek IJ and Lane TE - Microglial cell cytotoxicity of oligodendrocytes is mediated through nitric oxide. J Inmuno $\rrbracket$, 1993; 151:2132.

\$4 Howard M, Muchamuel T, Andrade S and Menon S - Imterleukin 10 protects mice from lethal endotoxemia. J Exp Med, 1993; 177:1205.

55 Smith SR, Terminelli C, Kenworth-Bot L, Calzetta A and Donkin I - The cooperative effects of TNF- $\alpha$ and IFN$\gamma$ are determining factors in the ability of IL-10 to protect mice from lethal endotoxemia. J Leuk Biol, 1994; $55: 711$.

56. Oswald IP, Wynn TA, Sher A and Janes SL - Interleukin 10 inhibits macrophage microbicidall activity by blocking the endogenous production of tumor mecrosis factor a required as a costimulatory factor for interferon $q$ induced activation. Proc Nat Acad Sci USA, 1992; 89:8676.

57 Joyce DA, Gibbons DP. Green P, Steer JH, Feldmann M and Brennan FM - Two inhibitors of pro-inflammatory cytokine release, interleukin-10 and interleukin-4, have contrasting effects on release of soluble p75 tumor necrosis factor by cultured monocytes. Eur J Immunol, 1994; 24:2699.

58. Leeuwenberg JFM, Jeunhomme TMAA and Buurman WA - Slow release of soluble TNF receptors by monocytes in vitro. J Immunol, $1994 ; 152 ; 4036$. 


\section{Thesis summary}

A lack of anti-self T and/or B cell reactivity or "self-tolerance" in the normal adult may be the result of clonal deletion, clonal anergy or peripheral suppression. Disregulation of these processes can be secondary to thymic involution, lack of appropriate cell-to-cell contact, and/or decreased immunoregulatory function of the lymphoid cells.

The aim of this study is to identify mechanisms at play in the ageing immune system that may lead to autoimmunity. In chapter 2 , in vitro work on T-B cell interaction in the ageing human is presented. The model used is a pokeweed mitogen (PWM) induced, T-cell-mediated suppression of Ig-secreting cell (ISC) formation by Staphylococcus aureus and $\mathrm{L}-2$. Unlike CD8 ${ }^{+} \mathrm{T}$ cells from young individuals, $\mathrm{CD}^{+} \mathrm{T}$ cells from aged individuals lack this immunoregulatory activity on autologous T-independently activated B cells. Dimaprit, a histamine type 2 receptor agonist, and intracellular CAMP raising agents, induce a similar T-cell mediated suppression of ISC formation in cells from young but not from aged individuals. Evaluation for an intracellular defect showed no age related decrease in CAMP upregulation by forskolin or dimaprit in peripheral blood T cells. TGF- $\beta$ is shown to play a role in mediating the suppressive effect of $T$ cells on the ISC response in this model. PWM-activated $T$ cells from young individuals show a significant increase in mRNA for TGF- $\beta$, while $T$ cells from aged individuals do not. This suggests that the decrease in immunoregulatory activity in peripheral blood from the elderly may partially be due to a decrease in TGF $\beta$ production by certain activated $\mathrm{T}$ cell subset( $(s)$.

Ageing is associated with $a$ change in the immune responses and an increase in autoimmune reactivity. In chapter 3 we furned to animal models to investigate whether potential self-reactive $T$ cells appear in aged animals and if so, to address the likely origin of these cells. Antibodies to the $\beta$ chain of the $T$ cell receptor were used to identify the presence of $T$ cells bearing potentially selfreactive TCR in the peripheral lymphoid tissues and blood of young, aged, and aged thymectomized (at 4-6 month of age; TX) mice. The study shows that obvious escape from the normal thymic deletion is seen only in very old ( 30 to 36 month old) euthymic mice. Responsiveness of forbidden $T$ cells to anti-V $\beta$ stimulation was detectable in 20-to-24 month old mice and particularly in aged TX mice, as compared to young mice. "Therefore it seems most likely that the functionally responding "forbidden" $T$ cells in the 20-to-24 month old mice are not of recent thymic origin.

Not all auto-antigens are presented within the thymus, such that self-reactive $\mathrm{T}$ cells can be released to the periphery and only then encounter for the first time the self-antigen. In such cases autoimmune responses can be induced and anti-self tolerance may be manipulated. In chapter 4. different mechanisms to prevent autoimmune disease in animals are studied. Resistance to experimental allergic encephalomyelitis (EAE) induction by homogenized myelin (MSCH) in complete adjuvant and pertussigen in SJL mice is obtained one week after intravenous injection of PLP 139-151 coupled to spleen cells. Immunoregulation is a mechanism which is important in this form of resistance as tolerance can be induced by transferring spleen cells enriched for $\mathrm{CDB}^{+}$ $T$ cells. Anergy is probably the main mechanism in inducing this resistance to EAE induction 
because administration of IL-2 can reverse the tolerance, but only when given starting three days after the PLP-coupled spleen cells. Changes in the cytokine profile of the response to antigen is an important aspect of the tolerance induced by antigen-coupled spleen cells. Immunomodulation by cytokines that affect the Th1/Th2 cell ratio shows that short (1-2 weeks) daily pretreatment with LL-2 or TGF- $\beta 2$ slightly decreases the susceptibility to subsequent EAE induction. IL-4 has only an effect if administered for a long period of time ( 8 weeks) prior to immunization, while IL-10 and IL-12 have no effect under these conditions. When administered after immunization with MSCH (day 0), TGF $\beta 2$ protects against development of EAE when given on days 5-9 after immunization, IL-4 protects when given specifically on days $0-4$ and less so when given later or for a prolonged period of time. IL-12 significantly increases the severity and mortality of EAE when given on days $0-4$, while $I L-10$ has no effect under these conditions. Thus, it appears that the severity of EAE can be altered through the promotion of Th2 or Th1 cell development during the immune response to encephalitogenic auto-antigen by $\mathrm{IL}-4$ and $\mathrm{IL}-12$, respectively.

Autoimmune diseases may present clinically with spontaneous remissions and relapses. As presented in chapter 5, the superantigen staphylococcal enterotoxin B (SEB) can induce relapses in $50 \%$ of animals that have partially or completely recovered from acute EAE. This capacity of SEB is presumabiy a result of reactivation of myelin reactive and SEB responsive $T$ cells, which vary according to the mouse strain used. TNF- $\alpha$ also induces EAE relapses in recovered mice. IL10 and $\mathrm{TGF}-\beta$ lower the incidence of EAE relapses when given simultaneously with TNF- $\alpha$ or SEB, respectively. In this model, it appears that endogenous IL-10 limits the susceptibility to induction of EAE relapses, as anti-IL-10 increases both the incidence and severity of such relapses.

\section{Conclusions}

These studies suggest that in the Thl cell mediated organ specific form of autoimmunity studied here, EAE, protective effects may be obtained by $I-4, \Pi L-10$ and TGF- $\beta$ depending on the temporal relationship between the administration of the cytokine and the induction of the autoimmune disease. $\mathbb{I L}_{-4}$ has to be given early during induction to be effective, TGF- $\beta$ during development of lesions, and $\Pi L-10$ may prevent TNF- $\alpha$ induced as well as spontaneous relapses.

Two reasons for deregulation of $B$ cell activation in aged subjects were uncovered:

Firstly, whille no evidence was found that "forbidden" anti-self reactive $C D 4^{*} \mathrm{~T}$ cells escaped from the thymus, some anti-self responsive $\mathrm{CD4}^{+}$cells, probably of extrathymic origin, did appear in the periphery of aged mice. Such cells could potentially promote syngeneic B cell activation.

Secondly, it was found that defective production of TGF- $\beta$ by $T$ cells from aged individuals may play a role in the loss of $B$ cell suppression by autologous PWM activated CD ${ }^{*} \mathrm{~T}$ cells.

\section{Future prospects}

The interesting effect of TGF- $\beta$ on autoimmunity and, in particular, the role of TGF- $\beta$ production by $\mathrm{T}$ cells themselves, needs to be explored in more detail. 


\section{Samenvatting}

In de gezonde volwassene wordt de afwezigheid van $T$ of $B$ lymfocyt reactiviteit tegen zelfantigenen, c.q. "zelftolerantie", toegeschreven aan clonale vernietiging, clonale anergie of perifere onderdrukking. Involutie van de thymus, onvoldoende dan wel onjuiste cel-cel interactie, en/of een verminderde immunoregulatoire functie van lymphocyten kan éen of meer van bovenbeschreven mechanismen, die ter grondslag liggen aan zelftolerantie, beinvloeden waarna autoimmuniteit kan ontstaan.

De opzet van deze dissertatie was om in de ouder wordende mens, en in het muis proefdier model, processen te identificeren die een rol spelen in autoimmuniteit.

Hoofdstuk 2 is een studie die de T-B lymfocyt interactie van het verouderende immuunsysteem van de mens analyseert in een in vitro model waarbij $B$ lymfocyten van jonge of oudere mensen op een $T$ lymfocyt onafhankelijke wijze worden geactiveerd door hen te kweken met staphylococcus aureus en interleukine 2; hierdoor ontstaan immunoglobuline uitscheidende B cellen ("ISC"). Aan dit kweeksysteem worden T cellen toegevoegd al of niet gestimuleerd met "Pokeweed Mitogen" (PMW) een extract uit Noord Amerikaanse kruiden, dat immunoregulatoire activiteit in CD8 T cellen genereert en waarvan bekend is dat het de "ISC" onderdrukt. In tegenstelling tot CD8 $T$ cellen van jonge mensen, missen de $\mathrm{CD}^{+} \mathrm{T}$ cellen van ouderen het inmunoregulatoire effect op de ISC differentiatie. Een histamine type 2 receptor agonist die tevens de intracellulaire concentratie van CAMP verhoogd, nl. "Dimaprit", induceert eveneens een $T$ cel veroorzaakte onderdrukking van "ISC" formatie in jonge maar miet in oude mensen. Deze verschillen tussen jong en oud kunnen niet verklaard worden door een leeftijdsafhankelijke afname van het vermogen van perifere bloedlymphocyten om intracellulair cAMP aan te maken. Van "transforming growth factor $\beta$ " (TGF- $\beta$ ) kon echter well aangetoond worden dat het een rol speelt, nl. (mede)verantwoordelijk voor het onderdrukkende effect van T cellen op de ISC activatie, in bovenbeschreven in vitro model. Immers "PWM" geactiveerde $\mathrm{T}$ cellen van jonge, maar niet van oudere mensen, vertoonden significante toename van boodschapper RNA ("mRNA") voor TGF- $\beta$. Deze bevindingen suggereren dat de afname van immunoregulatoire (T) cel activiteit bij de oudere mens een gevolg zou kunnen zijn van de afname van TGF- $\beta$ produktie in bepaalde geactiveerde $T$ cellen. Veroudering gaat enerzijds samen met veranderingen in immuunreactiviteit (zie boven) en anderzijds met een toename van autoimmutnreacties.

In hoofdstuk 3 beschreven wij dierexperimenteel onderzoek waarbij de vraag werd gesteld of (in potentie) autoreactieve $T$ cellen aantoonbaar zijn bij oudere muizen; en zo ja wat was dan de herkomst van deze cellen. De proefopzet berust op het gegeven dat van antilichamen gerich tegen het variabele deel (V $\beta$ regio) van de T lymfocyt receptor (TCR) gebruik kan worden gemaakt om dit $T$ cel repertoire te toetsen, inbegrepen die TCR receptoren dragende cellen die normaliter door de thymus vernietigd worden omdat zij een interactie kurnen aangaan met zelfantigenen. Deze worden derhalve normaliter niet in het perifere bloed en lymfoide weefsel aangetroffen. 
Met deze antilichamen, gericht tegen "verboden" TCR (nl. antizelf) receptor, werd vervolgens nagegaan bij jonge als ook bij oude muizen zonder of na voorafgaande verwijdering wan de thymus bij een leeftijd van 4 tot 6 masnden, of zulke autoreactieve $T$ cellen aantoonbaar waren. Bij jonge muizen waren ze niet aantoonbaar. Twee jaar oude muizen, met name na voorafgaande thymectomie, lieten soms wel zulke autoreactieve cellen in de periferie zien die bovendien geactiveerd konden worden (deling) wanneer hun lymfocyten in kweek werden gebracht met bovenbeschreven antilichamen. Driejarige muizen vertoonden meer autoreactieve $T$ cellen in de periferie vergeleken met tweejarige muizen. De slotsom van deze experimenten is dat de autoreactieve T cellen aantoonbaar in tweejarige muizen niet "recent" vanuit de thymus naar de periferie zijn gemigreerd.

Aangezien niet alle autoantigenen in de thymus aanwezig zijn volgt daaruit dat bepaalde autoreactieve $\mathrm{T}$ cellen niet door de thymus kunnen worden geëlimineerd en worden doorgelaten naar de periferie waar zij dan een autoanitigeen (voor het eerst) kunnen ontmoeten. Dit impliceert dat autoimmuunziekten kunnen worden opgewekt en tolerantie tegen zelf kan worden gemanipuleerd zoals beschreven wordt in Hoofdstuk 4 . In dit hoofdstuk worden verschillende manieren beschreven om autoimmunziekten te verhinderen in het dierexperimentele model wan de "experimentele allergische encephalomyelitis" (EAE). In dit model - wat wel als proefdier equivalent voor multiple sclerose wordt gebruikt - worden muizen geimmuniseerd met "ruggemerg" specifieke antigenen zoals "Myelin Basic Protein" (MBP) en proteolipide eiwit (PLP) in een emulsie van Freund Compleet Adjuvans wat bestaat uit oliën met gedode mycobactetiën. Na immunisatie van antigeen in deze emulsie worden autoreactieve CD4 T cellen geactiveerd die vervolgens een immunologische ontstekingsreactie veroorzaken in hersenen en ruggemerg. In het werk beschreven in hoofdstuk 4 werd nagegaan of muizen beschermd konden worden tegen EAE op de volgende manier. $\mathrm{EAE}$ werd opgewekt door muizen te immuniseren met een ruggemerg homogenaat of PLP in Freund Compleet Adjuvans; na 1 à 2 dagen werd nog een additioneel adjuvans ( $n$ l. een eiwit extract wan Bordetella Pertussis) intraveneus toegediend om de immuunrespons te verhogen: zulke muizen krijgen na 10 tot 15 dagen EAE. Wanneer nu het antigeen (PLP) gekoppeld wordt aan miltcellen en 1 week vór bovenstaande immunisaties intraveneus wordt toegediend krijgen zij geen EAE - noch jonge noch oude muizen - d.w.z. zij zijn tolerant of resistent geworden. Deze resistentie kan worden overgebracht op andere muizen door het overbrengen van $\mathrm{CD}^{+} \mathrm{T}$ cellen. Waarschijnlijk is $\mathrm{T}$ cel anergie het voornaamste mechanisme hier omdat toediening van interleukine 2 de PLP-milt cel geïnduceerde tolerantie te niet doet mits het 3 dagen na toediening van de PLP-milt cel suspensie wordt gegeven. Een wweede manier om resistentie tegen EAE op te wekken bestaat uit het veranderen wan dejalans ussen $\mathrm{T}$ helper $\mathbb{1} / \mathrm{T}$ helper 2 cellen (Th1/Th2), die verscheidene cytokines produceren $0 . \mathrm{a}$ interleukine 4 en 10 (Th2) en interleukine 2 , tumor necrosis factor en interferon $\gamma$ (Th1). Vóorbehandeling met interleukine 2 of TGF 32 14 dagen lang vóór het opwekken van EAE geeft een geringe afname aan het proefdier voor het ontwikkelen van EAE; interleukine 10 (remt de produktie van Interferon $\gamma$ ) en interleukine 12 toediening heeft geen effect; interleukine 4 toediening wel, mits 8 weken lang toegediend wóór de immunisatie. Indien toegediend na de immunisatie, beschermt TGF $\beta$ tegen EAE mits toegediend op dag 5 tot 9 na de immunisatie, en interleukine 4 wanneer toegediend op de dag van de immunisatie en de daarop volgende 4 dagen. Interleukine 12 wat de Th helper 1 response (en Interferon $\gamma$ produktie) stimuleert verergert de 
ernst van de EAE wanneer toegediend op de dag van de immunisatie en de eerstvolgende 4 dagen; onder deze omstandigheden heeft interleukine 10 geen effect. Kortom toediening van deze cytokines vóór immunisatie heeft een gering effect maar behoeft de aanwezigheid van autoreactieve $T$ cellen opgewekt door de immunisatie: de paradoxale effecten van IL4 (Th2 produkt) en interleukine 12 (bevordert Th1) suggereren dat (modulatie van) de Th1/Th2 "balans" de ernst van de EAE bepaalt. Autoimmuun ziekten, waaronder multiple sclerose, worden klimisch gekarakteriseerd door spontane remissies en rechutes. De wijze waarop dit gebeurt is niet bekend en onderwerp van discussie waarbij onder meer is gesuggereerd dat het superantigeen Staphilococcus enterotoxine B (SEB) een rechute autoimmuun ziekte kan veroorzaken door stimulatie van autoreactieve T' cellen. Deze hypothese werd getoetst door na te gaan of toediening van SEB aan muizen die een partiële dan wel complete remissie thadden van EAE een rechute opwekt. Hierbij werd gevonden dat in $50 \%$ van de (SJL) muizen SEB een milde rechute EAE kon opwekken wanneer toegediend 1 i 2 maanden na remissie van EAE; tenminste é̉n van de VB/TCR's die proteolipide (PLP) herkennen in deze muizen reageert ook met SEB. Het vermogen van SEB om een rechute op te wekken blijkt derhalve bepaald door het vermogen autoreactieve $\mathrm{T}$ cellen tegen PLP (of MBP) te reactiveren. Tumor necrosis factor $\alpha$ (TNF $\alpha$ ) toegediend aan muizen in remissie van EAE veroorzaakte eveneens een rechute. Toediening van IL 10 verminderde de frequentie van rechutes van EAE na toediening van TNF $\alpha$ en toediening van TGFB verminderde SEB geinduceerde rechutes. Tenslotte bleek dat endogeen $\mathbb{I L} \| 0$ de gevoeligheid voor rechutes van EAE verminderde omdat na toediening van antilichamen tegen IL 10 zowel de frequentie als de emst van de rechutes toenam.

\section{Conclusies}

Deze studie toont aan dat in het Th1 model van autoimmuniteit, nl. EAE, ILA, IL10 en TGF $\beta$ beschermend werken en dat deze bescherming afhangt van het tijdstip van toedienen in relatie tot de inductie van EAE. IL4 moet vroeg na inductie worden gegeven, TGF $\beta$ moet worden toegediend tijdens de effector fase wanneer de lesies zich ontwikkelen, en IL10 kan TNF $\alpha$ geluxeerde dan wel spontane rechutes verhinderen.

Twee oorzaken voor ontregelde B cel activiteit werden aangetoond bij veroudering. Hoewel er geen ontsnapping van "werboden" antizelf reactieve $T$ cellen uit de thymus aantoonbaar was bleken antizelf reactieve CD4 T cellen aantoonbaar in de periferie van de oudere muizen; deze cellen lijken van extrathymale oorsprong. Zulke cellen kunnen in theorie syngene B cel activatie veroorzaken. Een tweede observatie was dat deficiènte produktie van TGF $\beta$ door $\mathrm{T}$ cellen van oudere mensen een rol kan spelen in het verlies van B cel suppressie door autologe, door PWM geactiveerde, $\mathrm{CD} 8^{*} \mathrm{~T}$ cellen.

\section{Toekomst}

De ro』van TGF B bij autoimmun ziekten, in het bijzonder de rol van TGF $\beta$ produktie door $T$ cellen verdient nader onderzocht te worden. 



\section{Acknowledgments}

I am gratefull to all those who have stood by me in moments of dispair and hard work to produce these scientific results. Particularly, I am gratefull to Dr. Thorbecke whom I admire deeply, and who has inspired me through the years to learn and to explore the field of experimental cellular immunology. Dr. van Breda Vriesman who directed me as a medical student towards scientific research, and through whom I met Dr. Thorbecke. Many more are those I wish to thank, too numerous to mention. I am most gratefull to my little family, my husband, who stood beside me during these past years, and continues to support me through my resident years at Yale. 


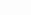




\section{Publications}

Crisi GM and Belsito DV - Contact urticaria to latex in a patient with immediate hypersensitivity to banana, avocado and peach. Contact Dermatitis, 1993; 28:247-248.

Santambrogio L, Crisi GM, Leu J, Hochwald GM, Ryan T and Thorbecke GJ - Tolerogenic forms of auto-antigens and cytokines in the induction of resistance to experimental allergic encephalomyelitis. J Neuroimmunol, 1995; 58:211-222.

Crisi GM, Santambrogio L, Hochwald GM, Smith RS, Carlino J and Thorbecke GJ Staphylococcal enterotoxin B and tumor-necrosis factor- $\alpha$-induced relapses of experimental allergic encephalomyelitis: protection by transforming growth factor- $\beta$ and interleukin-10. Eur $J$ Immunol, 1995; 25:3035-3040.

Crisi GM, Tsiagbe VK, Russo C, Basch RS and Thorbecke GJ - Evaluation of presence and functional activity of potentially self-reactive T cells in aged mice. Int Immunol, 1996; 8:387-395.

Crisi GM, Katz IR, Zucker MB and Thorbecke GJ - Induction of inhibitory activity for B cell differentiation in human CD8 T cells with pokeweed mitogen, dimaprit and $\mathrm{CAMP}$ upregulating agents: counter suppressive effect of Platelet Factor 4. Cell Immunol, 1996; 172:205-216.

Crisi GM, LZ Chen, C Huang and GI Thorbecke - Age-related loss of immunoregulatory function in peripheral blood CD8 T cells. Mech Ageing Dev, 1998 (in press).

Crisi GM, Katz IR, Zucker MB and Thorbecke GJ - Contrasuppressive effect of platelet factor 4 (PF4) in pokeweed mitogen induced suppression by human CD8 T cells. J Immunol, 1993; 150:191A.

Crisi GM and Thorbecke GJ - Histamine type 2 receptor (H2-R) triggering causes CD8 T cells to suppress $B$ cell differentiation in peripheral blood from young but not from aged individuals. FASEB J, 1994; 8:A1915.

Santambrogio L, Crisi GM, Hochwald GM and Thorbecke GJ - Mechanism of resistance to acute experimental allergic encephalomyelitis. (AEAE) in SJL mice induced by PLP-coupled spleen cells. FASEB J, 1994; 8:A243.

Santambrogio L, Crisi GM, Hochwald GM, Palladino MA and Thorbecke GJ - Resistance to experimental allergic encephalomyelitis in SIL mice after injection of PLP-coupled spleen cells: T cell anergy, suppression and immune deviation? 12th Eur. Immunol.Mtg, Barcelona, Spain.

Crisi GM, Santambrogio L, Hochwald GM, Smith RS, Carlino J and Thorbecke GJ - S. Enterotoxin $B$ (SEB) and Tumor necrosis factor- $\alpha$ (TNF) induced relapses of experimental allergic encephalomyelitis (EAE). The 9th International Congress of Immunology, San Francisco, 1995. 



\section{Curriculum vitae}

Giovanna was born in 1962 in Gronsveld, a village near Maastricht in southern Holland. She spent the first three years of her life in the USA, then moved to Italy where she grew up at the sea shore. In 1977 her family moved back to Holland. After completing Atheneum in Vise, Belgium, she got accepted at the Medical Faculty, University of Limburg, Maastricht. After graduating she moved to New York where she obtained a research postdoctoral fellowship at New York University Medical Center from 1991 to 1996. At present she is in the second year of residency in the Department of Pathology at Yale University School of Medicine. 